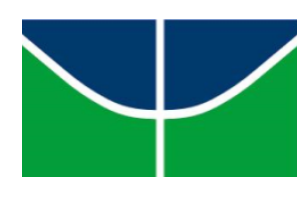

UNIVERSIDADE DE BRASÍLIA - UnB

FACULDADE DE EDUCAÇÃO - FE

PROGRAMA DE PÓS-GRADUAÇÃO EM EDUCAÇÃO - PPGE

LINHA DE PESQUISA: ESTUDOS COMPARADOS EM EDUCAÇÃO - ECOE

JAILTON LOPES VICENTE

ANÁLISE DO DISCURSO SOBRE SUCESSO E FRACASSO ESCOLAR NO BRASIL: UM ESTUDO COMPARADO SOBRE AS REPERCUSSÕES NA MÍDIA ON-LINE (2000 - 2016)

Brasília, DF

2016 
Ficha catalográfica elaborada automaticamente, com os dados fornecidos pelo(a) autor(a)

Vicente, Jailton Lopes

Análise do discurso sobre sucesso e fracasso

escolar no Brasil: um estudo comparado sobre as

repercussões na mídia on-line (2000 - 2016) / Jailton

Lopes Vicente; orientador Wivian Weller. -- Brasília, 2016.

$132 \mathrm{p}$.

Dissertação (Mestrado - Mestrado em Educação) -Universidade de Brasília, 2016.

1. Educação Internacional e Comparada. 2. Análise de Discurso. 3. Fracasso Escolar. 4. Sucesso

Escolar. 5. Mídia. I. Weller, Wivian, orient. II. Título. 
ANÁLISE DO DISCURSO SOBRE SUCESSO E FRACASSO ESCOLAR NO BRASIL: UM ESTUDO COMPARADO SOBRE AS REPERCUSSÕES NA MÍDIA ON-LINE (2000 - 2016)

Defesa de Dissertação de Mestrado apresentada ao Programa de Pós-Graduação da Faculdade de Educação da Universidade de Brasília, na Linha de Pesquisa Estudos Comparados em Educação, sob a orientação da Professora Doutora Wivian Weller. 


\section{ANÁLISE DO DISCURSO SOBRE SUCESSO E FRACASSO ESCOLAR NO BRASIL: UM ESTUDO COMPARADO SOBRE AS REPERCUSSÕES NA MÍDIA ON-LINE (2000 - 2016)}

Defesa de Dissertação de Mestrado apresentada ao Programa de Pós-Graduação da Faculdade de Educação da Universidade de Brasília, na Linha de Pesquisa Estudos Comparados em Educação, sob a orientação da Professora Doutora Wivian Weller.

\section{Banca Examinadora}

Prof. ${ }^{\text {a }}$ Dr. ${ }^{\text {a }}$ Wivian Weller (Orientadora - FE/UnB)

Prof. Dr. Célio da Cunha (Examinador Externo - UCB)

Prof. Dr. Marcelo Pereira do Amaral (Examinador Externo)

Prof. ${ }^{a}$ Dr. ${ }^{a}$ Raquel de Almeida Moraes (Examinadora suplente - UnB/Matr.: 146641)

Brasília, 09 de dezembro de 2016. 
Dedico este trabalho, primeiramente, a Deus, autor de tudo e sustentação na minha jornada.

Dedico, também, aos meus três lindos filhos: Miguel, Júlia e Heloísa. Mesmo nos dias em que estive ausente, sempre estavam com um sorriso para me receber e preencher minha vida com uma verdadeira alegria.

Por fim, uma dedicatória mais do que especial à minha esposa, Maria Juliana, que sempre me entendeu, sempre me encorajou, sempre teve paciência, sempre soube ser a esposa perfeita que Deus pensou para minha vida. 


\section{AGRADECIMENTOS}

Primeiramente, agradeço à professora Dra. Wivian Weller, que confiou plenamente no meu trabalho e soube conduzir com muita tranquilidade todas atividades desenvolvidas nesses dois anos.

Agradeço, ainda, ao professor Dr. Marcelo Pereira do Amaral, ao professor Dr. Célio da Cunha e à professora Dra. Raquel de Almeida Moraes por terem aceitado participar da banca avaliadora desta dissertação.

De forma semelhante, agradeço à Secretaria de Educação do Distrito Federal, pela consessão de afastamento remunerado para estudos, crucial para a realização deste trabalho.

Meu agradecimento às colegas de universidade que sempre demonstraram seu apoio e amizade, em espcial: Cilene Vilarins, Ana Carla e Ellem Cintra.

Agradeço imensamente aos meus pais, minhas irmãs, minha sogra e a todos que direta e indiretamente colaboraram e deram suporte para que eu tivesse tranquilidade para estudar.

Por fim, o meu muito obrigado à minha esposa, Maria Juliana, que sabe me dizer o que é preciso no momento certo. Agradeço muito por você ter participado de todos os momentos difíceis que antecederam este momento de extrema alegria. 


\section{SUMÁRIO}

\section{Resumo}

Abstract

Introdução

1.2 - Análise de Discurso: possibilidades teórico-metodológicas para a Educação Internacional

e Comparada 30

1.3 - Organização da pesquisa 48

Capítulo 2 - Reprovação e progressão continuada: estratégias de construção e circulação dos discursos 50

2.1. Reprovação em pauta .............................................................. 50

2.1.1 - Texto 1: A arqueologia da reprovação (2000) ....................................... 50

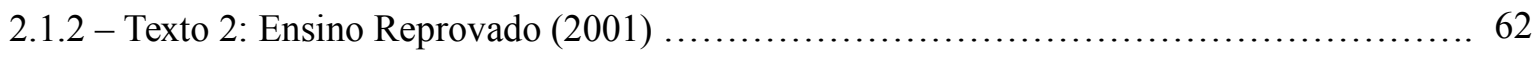

2.2. Escolas de referência como modelo de sucesso escolar .................................. 69

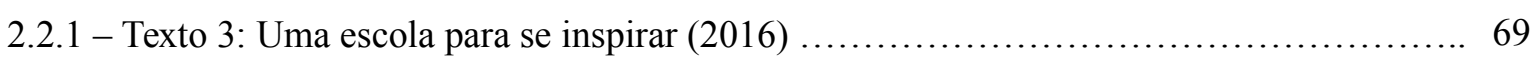

2.2.2 - Texto 4: Colégio Pedro II, no Rio, decide manter alunos repetentes (2015) .............. 76

2.3. Análise Comparativa ............................................................ 81

2.3.1 - Análise comparada dos textos 1 e 2 ........................................ 81

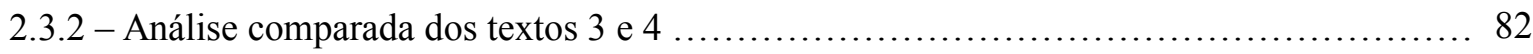

2.3.3 - Comparação dos discursos sobre reprovação e sucesso escolar ......................... 85

Capítulo 3 - Por que o PISA se tornou referência nos discursos sobre sucesso/fracasso escolar?

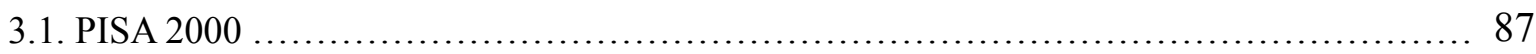

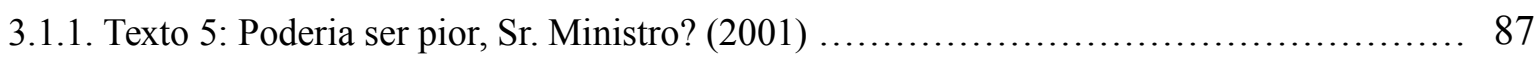

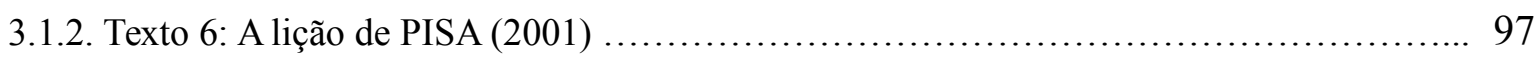




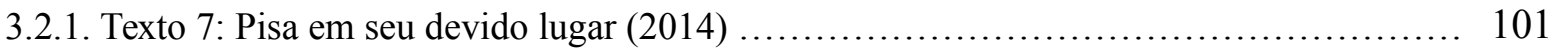

3.2.2. Texto 8: Brasil teve 'grande avanço' no Pisa, afirma Mercadante (2013) .................. 109

3.3. Comparação dos discursos sobre sucesso/fracasso escolar a partir dos resultados do Pisa

Referências 


\title{
RESUMO
}

\section{Análise do discurso sobre sucesso e fracasso escolar no Brasil: um estudo comparado sobre as repercussões na mídia on-line (2000 - 2016)}

\begin{abstract}
A Educação Internacional e Comparada tem se constituído como um campo extremamente complexo tanto no que se refere ao seu objeto de estudo, cada vez mais multifacetado, quanto em relação aos aspectos teórico-metodológicos. Para dar conta dessa crescente demanda, é preciso usar outros dispositivos analíticos que possam responder aos questionamentos que surgem no âmbito dos estudos comparados em educação. Nesse sentido, este estudo utiliza o referencial teórico metodológico da Análise de Discurso francesa como articulação metodológica no campo da Educação Internacional e Comparada. Foram analisados discursos veiculados na mídia on-line sobre fracasso escolar (reprovação, distorção idade-série, evasão) e também sobre sucesso na escola no período de 2000 a 2016. O objetivo é, portanto, fazer um estudo comparado temporal diacrônico, buscando compreender como se deu o processo de construção de sentidos, observando as interações discursivas no tempo, isto é, como um discurso aponta para outro no passando e é, assim, sustentado por ele. Foram analisados textos publicados na internet por veículos de grande circulação para perceber como esses discursos são articulados e como circulam na sociedade. Além disso, foram analisados os efeitos de sentido provocados pela utilização dos resultados nos exames em larga escala (Saeb e Pisa) como balizadores da qualidade ou do fracasso de um sistema de ensino, mostrando que não são dados objetivos por si mesmos, mas um efeito ideológico produzido no interior do discurso. A partir das comparações entre os textos, constatou-se que o discurso é colocado como o espaço privilegiado para o entendimento sobre o modo como as sociedades se organizam a respeito dos mais variados temas. Além disso, a articulação da Educação Internacional e Comparada com a Análise de Discurso mostrou-se produtiva, por permitir acesso a novos gestos de interpretação, permitindo, a partir da comparação entre textos, perceber como só discursos são articulados em determinado contexto sócio-histórico.
\end{abstract}

Palavras-chave: Educação Internacional e Comparada, Análise de Discurso, fracasso escolar, sucesso escolar, mídia 


\section{ABSTRACT \\ Analysis of the discourse on school success and failure in Brazil: a comparative study on the repercussions in the on line media $(2000-2016)$}

International and Comparative Education has become an extremely complex field both in terms of its increasingly multifaceted object of study and in relation to theoretical and methodological aspects. To meet this growing demand, we need to use other analytical devices that can answer the questions that arise in comparative studies in education. In this sense, this study uses the theoretical methodological reference of the French Discourse Analysis as a methodological articulation in the field of International and Comparative Education. We analyzed online discourses about school failure (failure, age-grade distortion, avoidance) and also about school success in the period from 2000 to 2016. The objective is, therefore, to make a diachronic comparative temporal study, seeking to understand As the process of sense construction took place, observing the discursive interactions in time, that is, as one discourse points to another in passing and is thus sustained by it. We analyzed texts published on the internet by vehicles of great circulation to understand how these discourses are articulated and how they circulate in society. In addition, we analyzed the effects of sense provoked by the use of the results in the large scale exams (Saeb and Pisa) as indicators of the quality or failure of a teaching system, showing that they are not objective data by themselves, but an effect Ideologically produced within the discourse. From the comparisons between the texts, it was found that the discourse is placed as the privileged space for the understanding of how societies organize themselves on the most varied subjects. In addition, the articulation of International and Comparative Education with Discourse Analysis has proved to be productive, allowing access to new interpretive gestures, allowing, from the comparison between texts, to understand how only discourses are articulated in a particular sociohistorical context.

Keywords: International and Comparative Education. Discourse Analysis. School Failure. School Success. Media. 


\section{Introdução}

Caminhar sobre um terreno instável pode, sem o preparo adequado, fazer do simples ato de andar uma atividade extremamente perigosa. Igualmente, adentrar um campo do saber sem, contudo, conhecer suas bases, é querer patinar no gelo com calçado de sapateado, ou seja, pode-se até conseguir, mas a muito custo e não sem algum risco. Do mesmo modo, situar-se no campo da Educação Internacional e Comparada (EIC) envolve cuidados semelhantes a esse.

Assim, três desafios se colocam já no início deste trabalho: (1) entender a constituição essencialmente heterogênea da EIC; (2) Determinar "a diferença entre a comparação como uma operação mental universal embutida na vida social cotidiana e a comparação como um método científico social. (SCHRIEWER, 2009, p. 67); e (3) estabelecer qual o caminho teórico-metodológico e fazer a articulação propriamente dita da Educação Internacional e Comparada com outra área do saber.

Em relação ao desafio (1), é preciso destacar que se trata de um campo constituído sobre uma base heterogênea e, consequentemente, trabalha sempre nos seus limites, nas suas fronteiras, entre as ciências humanas e sociais, entre a técnica, a metodologia e a teoria sem, no entanto, fixar-se em um ponto específico, conforme afirma Ferreira (2009):

a Educação Comparada é necessariamente múltipla e complexa. Ela precisa de conhecimentos e de complementos provenientes de outras áreas científicas, nomeadamente da História, da Sociologia da Economia, para além de outras especialidades das Ciências da Educação. (p. 138)

É, dessa forma, um campo do saber que não tem na autossuficiência o eixo central, pois ela precisa de outras áreas para se constituir enquanto tal, o que não necessariamente pode ser classificado como um problema. A essência da Educação Internacional e Comparada, a partir dessa visão, está justamente na sua heterogeneidade constitutiva, fato que gera constantes críticas no sentido de que seria "um campo muitas vezes apreendido como epistemologicamente pouco fundamentado. Metodológica e teoricamente fragmentada [...]” (MALET, 2004, 1302).

Por outro lado, esse modo de constituição pode ser também considerado o seu maior trunfo, na medida em que é um campo que tem na complexidade seu elemento nodal, não somente do ponto de vista da sua formação, mas nas possibilidades de abordagens que 
múltiplas perspectivas podem proporcionar. Cabe ao pesquisador saber explorar essa característica.

O segundo desafio a ser enfrentado é, sem dúvida, relacionado à pergunta "o que é comparar?". Vejamos o que Bonitatibus (1989) diz a esse respeito:

A comparação [...] é uma atitude mental, uma forma intuitiva de conhecimento do ser humano. Toda vez que nos deparamos com um fato novo, com algo desconhecido, procuramos relacioná-lo a outros da mesma espécie ou categoria, já vivenciados, conhecidos ou experienciados por nós e, dessa forma, apreendê-lo e incorporá-lo, por sua vez, ao nosso cabedal de conhecimentos. É assim que se processa o conhecimento humano e é nesse sentido que afirmamos ser, a comparação, uma atitude mental espontânea, intuitiva. (p. 4)

Entendida dessa forma, o ato comparativo torna-se parte do modo de funcionar da mente humana e, consequentemente, sem qualquer conotação metodológica, pois não é um processo sobre o qual haja um procedimento prévio reflexivo, mas, simplesmente, a mente humana tem dificuldades em lidar com elementos isolados, comparando-os para estabelecer parâmetros. Assim, será preciso atacar este ponto, procurando mostrar como o método comparativo rompe com essa visão, apresentando um conjunto de possibilidades metodológicas que permitem ao pesquisador comparar não somente um ato mental, mas como um ato mental intencional e regido por um aparato teórico-metodológico que lhe dá sustentação.

O terceiro ponto refere-se ao caminho metodológico que a Educação Internacional e Comparada assume para, enfim, ser plenamente capaz de realizar sua tarefa primordial: fazer comparações. O que parece óbvio num primeiro momento, mostra-se extremamente complexo, pois é preciso seguir o percurso reflexivo que propomos para compreender como se dará esse processo. Dessa maneira, é preciso compreender a constituição do campo da EIC a fim de entender como a heterogeneidade do campo pode operar a favor do pesquisador e, além disso, ter claro que se deve romper com a ideia de que, não obstante o ato de comparar seja parte do funcionamento da mente humana, um estudo comparado seja um processo natural, mas é fruto de um complexo processo de reflexão por parte do pesquisador. Tal condição desemboca na escolha do referencial teórico-metodológico, elemento central na construção da comparação propriamente dita.

Os desafios estão postos. É preciso enfrentá-los na perspectiva de que a construção de uma pesquisa comparativa em educação já se dá nesse processo reflexivo. A 
comparação será bem-sucedida na proporção dos esforços envidados nessa etapa, tão importante quanto o próprio ato de comparar.

Assim, a proposta de trabalho é fazer um estudo comparado de discursos sobre desempenho escolar veiculados na mídia on-line (especializada e leiga) de 2000 até 2016, a partir da articulação da Educação Internacional e Comparada com a Análise de Discurso (AD) francesa, destacando as seguintes categorias: reprovação e progressão continuada bem como sucesso e fracasso da educação brasileira em relação a países desenvolvidos.

Entretanto, falar em comparação de discursos implica escolhas metodológicas importantes para o curso da pesquisa. Inicialmente, o discurso, na perspectiva na AD, é um construto teórico e isso traz consequências para a análise. Dessa maneira, o discurso não está dado no texto de forma óbvia, mas é resultado do trabalho do analista que, a partir de um texto, tem acesso aos diferentes discursos. Segundo Orlandi $(1999,69)$, "Se o texto é unidade de análise, só pode sê-lo porque representa uma contrapartida à unidade teórica, o discurso, definido como efeito de sentidos entre locutores". Assim, os discursos é que serão comparados, mas a unidade de análise é o texto e, no caso específico deste estudo, aqueles veiculados na imprensa on-line.

Além disso, destaca-se que num único texto podem ser encontrados vários discursos, pois "Um sujeito não produz só um discurso; um discurso não é igual a um texto" (ORLANDI, 1999, p. 71). Dessa maneira, serão comparados os discursos em um único texto, isto é, cada reportagem terá uma análise interna dos discursos, uma vez que um estudo de mestrado não tem a envergadura necessária para se fazer a comparação entre os discursos presentes em diversos textos. Entretanto, é fundamental destacar que, para a Análise de Discurso,

\footnotetext{
Não se objetiva, nessa forma de análise, a exaustividade que chamamos horizontal, ou seja, em extensão, nem a completude, ou exaustividade em relação ao objeto empírico. Ele é inesgotável. Isto porque, por definição, todo discurso se estabelece na relação com um discurso anterior e aponta para outro. (ORLANDI, 1999, p. 62)
}

Assim, seria preciso analisar toda a cadeia de texto produzida em todas as partes do mundo, em todos os tempos a respeito do tema sobre o qual se deseja falar para alcançar a exaustividade horizontal na análise. Por outro lado, a AD busca a chamada exaustividade vertical, isto é, "em profundidade, leva a consequências teóricas relevantes e não se trata os ‘dados' como meras ilustrações” (ORLANDI, 1999, p. 63). Daí a opção metodológica de se 
analisar os textos verticalmente, focando nos discursos e sentidos movimentados pelos textos individualmente e não em relação a textos diferentes pois, exaurir todas as possibilidades, como mostrado, seria impossível.

Dizer, contudo, que cada um dos textos será analisado com exaustão vertical não significa que se trata de uma análise conclusiva. Para a $\mathrm{AD}$, todo texto é passível de novas interpretações, pois este processo não está no texto nem no sujeito, mas está na relação estabelecida entre ambos (cf. ORLANDI, 1999). Assim, sempre haverá possibilidades de os discursos serem apreendidos de outra perspectiva pois o desenho da pesquisa é de responsabilidade do analista e, dessa maneira, está situada em uma região muito específica do dizer, permitindo que a mudança na figura de quem analisa os discursos também produza significativas alterações no curso do processo de interpretação.

Assim, este estudo apresenta dois capítulos em que serão feitas análises discursivas dos textos selecionados.

No capítulo dois, o primeiro tema a ser abordado é Reprovação em pauta, em que serão comparados dois $\operatorname{textos}^{1}$ ( $A$ arqueologia da reprovação e Ensino reprovado) com abordagens diferentes, mas que transitam na mesma região discursiva. São textos cujos assuntos giram em torno o fracasso escolar nos mais diferentes aspectos. O objetivo é mostrar como os textos procuram articular reprovação, distorção idade-série, progressão continuada numa estrutura comparativa no discurso que, nem sempre, está posta de forma explícita. Em seguida, o tema é Escolas de referência como modelo de sucesso escolar, também a partir de dois textos (Uma escola para se inspirar e Colégio Pedro II, no Rio, decide manter alunos repetentes) e o centro do debate está nos discursos de qualidade escolar a partir de instituições que são consideradas modelo, sobretudo analisando as estruturas discursivas que constroem e mantêm esse tipo de escola como arquétipo da excelência.

$\mathrm{O}$ capítulo se encerra em duas frentes complementares. Na primeira delas, os discursos são comparados em pares, separadamente. Assim, os textos A arqueologia da reprovação (2000) e Ensino reprovado (2001), além de analisados individualmente, também são objeto de uma análise comparativa. O mesmo ocorre com os textos Uma escola para se inspirar (2016) e Colégio Pedro II, no Rio, decide manter alunos repetentes (2015). Numa

1 Para efeito de organização, os parágrafos dos originais dos textos jornalísticos foram numerados de forma sequencial e assim serão referidos nas análises a fim de tornar a leitura menos cansativa. Dessa forma, não serão citados trechos dos textos originais, mas a numeração definida por nós e que pode ser conferida nos apêndices, seguindo o modelo a seguir: o primeiro número indica o parágrafo e o segundo a linha. Por exemplo: trecho 5-1 representa a linha 1 do parágrafo 5. 
outra etapa, os quatro textos são comparados, configurando, dessa forma, uma análise diacrônica comparada.

O capítulo três seguirá exatamente a mesma sistemática de trabalho e tem como temática os discursos sobre o Pisa, especificamente as edições de 2000 (texto Poderia ser pior, Sr. Ministro? e A lição de PISA, ambos de 2001) e 2012 (Pisa em seu devido lugar, de 2014, e Brasil teve 'grande avanço' no Pisa, afirma Mercadante, de 2013), isto é, a primeira edição e a última com resultados divulgados até novembro de 2016. Por fim, os quatro textos serão comparados diacronicamente.

Assim sendo, O objetivo deste estudo é, portanto, fomentar uma discussão teórico-metodológica acerca da articulação da Educação Internacional e Comparada com a Análise de Discurso e, além disso realizar comparações de discurso a partir de textos veiculados na mídia on-line. É preciso destacar, contudo, que não se trata de mostrar que os textos estão errados ou há falhas na sua estrutura, mas mostrar como se deu o processo de construção dos sentidos e, portanto, promover leituras menos ingênuas que propiciem ver textos jornalísticos sobre temas educacionais não como mera informação mas como, também, trabalho ideológico. 


\section{Capítulo 1}

\section{O campo da Educação Internacional e Comparada}

\section{1 - Educação Internacional e Comparada: um campo aberto}

A Educação Internacional e Comparada está inserida nos estudos do campo da Educação (da Pedagogia). Tal afirmação parece óbvia, mas é fundamental para caracterizar o que é Educação Internacional e Comparada pois permite entender sua natureza e, assim, ser possível entender como localizá-la em relação à sua constituição epistemológica. É preciso, dessa forma, partir da premissa de que a Educação constitui um campo interdisciplinar em sua essência.

Como citado, entender esse processo é fundamental na medida em que o modo de funcionar da Educação Internacional e Comparada traz no seu cerne a maneira como a Educação, campo mais amplo, opera seus saberes, conforme afirma Bonitatibus (1989):

[...] a própria educação é multi ou interdisciplinar em seu processo e a Educação Comparada, ao tomar os sistemas e os fatos educacionais como objeto de seus estudos comparativos, não teria como fugir a esta mesma configuração. É possível entretanto que, no caso da Educação Comparada, a questão se torne um tanto mais complexa, nem tanto por não se limitar aos fatos educativos no âmbito de um único contexto mas, sim, por ampliá-lo, a fim de cobrir, em perspectiva comparativa, diferentes povos, culturas e "tempos" históricos. (p. 10)

A autora estabelece uma relação de complexidade crescente entre o campo mais amplo - Educação - e a EIC. A primeira é essencialmente complexa na abordagem do seu objeto e, consequentemente, os campos que dela derivam herdam, por assim dizer, seu caráter aberto e múltiplo. Nesse sentido, conforme Bonitatibus (1989) apresenta, a Educação Internacional e Comparada é complexa tanto por sua ligação fundamental com a Educação e, também, por abordar fatos educativos vinculados não somente a um único conceito bem como abrange "diferentes povos, culturas e 'tempos' históricos" (p. 10).

Situada a Educação Internacional e Comparada, é preciso, a partir de agora, compreender como se deu sua constituição. Segundo Kazamias (2012),

[...] a EIC vestiu diferentes costumes, tecidos em fios epistemológicos, metodológicos e ideológicos de diferentes colorações. Por conseguinte, 
mostrou-se sob diversas aparências, em grande parte refletindo as tendências e modas intelectuais, metodológicas e cultuais dos tempos. [...] Formulando de outro modo, ao refletir historicamente sobre a EIC como uma "ciência humana" [...] devo "teorizar" sobre "gerações" e "tipos" de discurso de Educação Internacional e Comparada.

É preciso, no entanto, ter cautela em relação a uma construção da história de uma disciplina ou de um campo pois não se pode incorrer na lógica do progresso científico (Nóvoa, 2009), na medida em que não se pretende argumentar no sentido de que hoje o campo está mais evoluído do que fora nos seus primórdios, mas a proposta é "reintroduzir talvez não coesão, mas, pelo menos, coerência e legibilidade [...]”, Malet (2004). Coerência e legibilidade não se confundem, porém, com linearidade, mas se relaciona com o processo de idas e vindas que caracterizam a história de uma disciplina. Assim, não se trata de afirmar que as fases da EIC são estanques entre si e em relação à história do pensamento, mas de deixar explícito como os movimentos do campo são mais tendenciosos para esta ou aquela direção, mas que não são unívocos e, sempre podem derivar para fases que pareciam estar esquecidas mas que voltam, muitas vezes, com outra roupagem, de acordo com a terminologia de Kazamias (2012).

Não se objetiva, no entanto, tratar minunciosamente aqui cada uma das fases, mas apenas traçar um panorama no percurso epistemológico e metodológico que o campo da Educação Internacional e Comparada vem atravessando desde a sua constituição.

Bonitatibus (1989) afirma que já há registros de estudos comparados em Educação em estudos na Antiguidade Clássica, em um período que pode ser definido como pré-científico. Entretanto, a Educação Internacional e Comparada tem sua primeira tentativa de sistematização enquanto campo do saber científico concretizada a partir dos escritos de Marc-Antoine Jullien de Paris (1817). Era um período com forte influência do positivismo, isto é, uma tendência em se buscar respostas por meio da ciência e, assim, tendo uma “concepção descritiva e estática do conhecimento" (MALET, 2004, p. 1305). Jullien de Paris escreveu que

o projeto de uma grande empreitada, (...) essa tendência universal rumo a uma mesma meta, a regeneração e o aperfeiçoamento da educação pública (...) Parece portanto necessário formar para essa ciência, como ocorreu com outros ramos de nossos conhecimentos, coleções de fatos e observações (...) para deles deduzir princípios certos, regras determinadas, e assim fazer da educação uma ciência aproximadamente positiva.(JULLIEN DE PARIS, 1962 , p. 8 e 13) 
A Educação Internacional e Comparada, segundo essa visão, deveria ser compreendida como um ramo científico como qualquer outro e, portanto, sujeita às regras do funcionamento objetivo, isto é, observação, sistematização, dedução, buscando a construção de princípios gerais que pudessem, dessa forma, ser aplicados em qualquer situação particular. Nessa mesma linha, tinha um objeto de estudo muito bem definido: os sistemas nacionais de ensino e a unidade básica de análise era o Estado-nação. De acordo com Lourenço Filho (2004), a função primeira da Educação Internacional e Comparada era "a descrição desses sistemas" (p. 33).

Como já dito anteriormente, é impossível traçar a história de um campo de estudo a partir de uma perspectiva linear e, dessa forma, essa concepção de Educação Internacional e Comparada ganhou novo destaque na década de 1960, por meio dos estudos de Noah e Eckstein (1969), numa fase que pode ser chamada neopositivista.

Assim, pode-se afirmar que a corrente positivista está em estreita relação com a fase conhecida como "naciocentrismo", que não teve seu foco na criação de um método para o campo da EIC, mas procurava caracterizar os sistemas de educação com o objetivo de determinar suas causas históricas e o modo como se organizavam (MALET, 2004). O que une as referidas tendências é o saber enciclopédico na base da sua constituição. A intenção era "pegar emprestado" (Bray, 2015), isto é, utilizar a base de dados construída e aplicar os conhecimentos em outro lugar, assumindo a forma de uma "Educação Internacional e Comparada aplicada", nos termos de Cowen (2006).

No entanto, Sadler (1979) já alertava a respeito dos problemas advindos da prática de transferir políticas e práticas educacionais sem considerar o contexto:

\begin{abstract}
Nós não podemos perambular à vontade entre os sistemas educacionais do mundo, como uma criança passeando por um jardim, e pegamos uma flor de um arbusto e algumas folhas de outro e esperamos obter uma nova planta, se juntarmos o que colhemos e plantarmos no jardim de casa (p. 49).
\end{abstract}

Esta afirmação é particularmente importante para nossa proposta pois Sadler resvala em dois aspectos fundamentais. O primeiro deles diz respeito ao caráter desbravador da EIC, na medida em que as pesquisas desse campo têm em sua essência a busca por conhecer o novo, o diferente. Assim, a imagem da criança passeando pelo jardim eram os representantes dos países indo ao estrangeiro buscar novas experiências no campo educacional a fim de aplicar depois em seus próprios países. Um campo aberto epistemologicamente é, portanto, muito mais vantajoso nesse momento, pois permite àquele 
que está em contato com outra cultura ter uma visão realmente aberta desse outro que é visitado. Assim, permite que, não se tente enquadrá-lo em uma única visão, mas usar a perspectiva que forma mais adequada a cada situação particular. O segundo ponto, ao contrário, vem justamente alertar que essa abertura da Educação Internacional e Comparada no que diz respeito ao seu modo de ver o outro não deve se traduzir em anarquia conceitual, metodológica, teórica, epistemológica. Dessa maneira, o rigor do pesquisador deve ser maior na proporção do desafio enfrentado, como é o caso das pesquisas no campo da EIC. No caso específico da fala de Sadler, o conceito de contexto deve ser o elemento norteador da comparação, pois ele é o balizador da relação do pesquisador com o sistema de ensino estrangeiro.

Ainda relacionada a essa visão mais prática da Educação Internacional e Comparada, encontramos a abordagem da "resolução de problemas", cujo autor principal é Brian Holmes (1958). Ela está profundamente ligada ao pragmatismo e tinha como perspectiva central uma forte base científica - como no positivismo - e, ao mesmo tempo, superava-o na forma da não generalização, isto é, o foco aqui não estava mais em transformar um fato educativo em universal para que pudesse se aplicado a qualquer situação indiscriminadamente. Segundo Malet (2004),

[...] é uma etapa importante na consolidação dessa perspectiva pragmáticoevolucionista Como ela não toma mais macrocontextos educativos como âmbito de comparação mas focaliza sua análise em fenômenos contextuais circunscritos, essa abordagem é caracterizada ao mesmo tempo por sua ambição científica e por preocupações pragmáticas e operacionais agudas. (p. 1308)

Trata-se de uma abordagem que se liga diretamente às questões levantadas pelo neopositivismo, mas com foco na resolução de problemas específicos - daí o nome "resolução de problemas" - não mais com o objetivo de estudar o sistema educacional como um todo, mas somente o ponto específico que apresenta o problema a ser solucionado.

A partir, no entanto, dos anos 1950 - período correspondente ao pós-guerra - o mundo assumiu uma nova configuração e, consequentemente, os estudos comparativos em educação também foram influenciados por esse novo arranjo mundial. Surgem, no contexto de reconstrução da Europa, a UNESCO, Banco Mundial e, depois, a OCDE. Para Malet (2004),

Se com o desenvolvimento dos organismos internacionais e das ferramentas de planejamento da educação, o comparatismo ampliou progressivamente seu campo de estudos e de intervenção, mais particularmente em direção aos 
países menos adiantados, às vezes isso se deu ao preço de conflitos a respeito do alcance ideológico dessas abordagens. Os defensores dessa concepção da Educação Internacional e Comparada consideram que a comparação tem por principal missão acompanhar os processos de modernização social e guiar as reformas educativas necessárias no campo da educação [...]. (p. 1309)

Esse é um período conhecido como intervencionismo em que surgem conflitos entre os interesses voltados à Educação e as questões políticas ou de "pilotagem" das reformas e das políticas educativas (MALET, 2004). Assim, os estudos tinham como objetivo principal avaliar a capacidade de países menos desenvolvidos no desenvolvimento das políticas educacionais. Além disso, o tempo político nem sempre (quase nunca) coincide com o tempo pedagógico ou com o científico e, nesse sentido, à Educação Internacional e Comparada era impossível conciliar essas duas perspectivas de modo que se observou, a partir dessa visão polarizada do papel da EIC, que o campo se mostrava frágil e, assim, sujeito às forças políticas vigentes.

Essa discussão abre, no entanto, espaço para uma outra abordagem no campo da Educação Internacional e Comparada: o comparatismo crítico. Segundo Malet (2004)

[...] essa perspectiva se erige contra formas de comparação consensualistas que encarnam, por seu etnocentrismo, uma forma moderna de colonialismo [...]. A Educação Internacional e Comparada, em seu programa pragmático, desabrochou dentro de um período pós-colonial, durante o qual a educação e a ajuda ao desenvolvimento representaram, para o Ocidente, os instrumentos de seu expansionismo cultural e ideológico, e com isso, um meio de assentar para si mesmo sua própria identidade [...]. (p. 1302)

Nessa perspectiva, a análise da natureza ideológica da postura dos países com relação às suas políticas gerais e, mais especificamente, aquelas voltadas para o campo educacional passa a ser o elemento central e, além disso, um debate teórico e ético é estabelecido pois, nessa abordagem, o ponto principal a ser analisado é como se dá o tratamento do outro e da sua cultura no desenvolvimento de ações no campo educacional.

Esse debate sobre ética na relação com o outro vai também se mostrar muito presente na discussão acerca da globalização, um dos pontos centrais para EIC a partir da década de 1990. Nesse mesmo movimento, vê-se um enfraquecimento do conceito de Estadonação e, ao mesmo tempo, percebe-se uma crescente preocupação com a noção de fragmentação das sociedades e do modo de vida das pessoas. Surge nas pesquisas situadas no campo da Educação Internacional e Comparada, a partir dessa discussão, um retorno à 
problematização da noção de contexto, já destacada anteriormente na proposta de Sadler (1979).

Nessa ótica, os países já não são considerados restritos às suas fronteiras, mas, de forma complexa, há um intrincado jogo de idas e vindas, provocando um movimento constante entre o global e o local, de modo que um dos papéis da EIC é, sem dúvida, posicionar-se a respeito dessa tensão, não assumindo a postura de que sempre o global interfere no local, mas que há um duplo movimento nesse processo, com ambas as partes influenciando-se mutuamente. Dessa forma, a globalização e a fragmentação participam na verdade de um mesmo processo de ampliação dos quadros espaciotemporais construídos pela modernidade [...] (MALET, 2004, p. 1314).

$\mathrm{Na}$ esteira dessa discussão acerca da globalização e, também, da fragmentação do mundo hoje, uma última abordagem a ser tratada é a hermenêutica ou perspectivas sóciohistóricas (NÓVOA, 2009). Trata-se de um modo diferente de abordar os fatos educativos, não mais tomados enquanto realidade puramente material, mas como elementos discursivos. Assim,

O objeto da comparação é [...] reconstruído: a análise abandona a referência aos contextos definidos pela visibilidade dos seus contornos geográficos, políticos ou sociais, referindo-se antes a contextos definidos segundo a invisibilidade das práticas discursivas que lhe conferem sentido. (NÓVOA, 2009, p. 49)

Vê-se aqui o alinhamento com a discussão acerca da globalização, pois a perspectiva hermenêutica é quase que uma consequência direta desse novo modo de conceber o Estado-nação, isto é, não mais segundo suas fronteiras geográficas, mas a partir da perspectiva de comunidades discursivas. Portanto, o que define um grupo não é mais o lugar propriamente, mas os sentidos compartilhados por um grupo, ainda que não estejam fisicamente reunidos em um local específico. Pode-se dizer que "[...] essa tendência contemporânea substitui progressivamente um modelo contextual e pragmático por um modelo textual que traduz a centralidade do discurso na construção dos fenômenos educativos" (MALET, 2004, p. 1316).

Nessa abordagem, o outro enquanto elemento central da comparação ainda está na mesma condição de antes, porém, assume agora um caráter diferente, pois se trata, na perspectiva hermenêutica, do trabalho com a "palavra encarnada, ou seja do sujeito" (MALET, 2004, p. 1317). Assim, não se está falando somente do indivíduo empírico, mas do 
sujeito no discurso, isto é, daquele que ocupa um lugar na linguagem e, consequentemente, participa de uma comunidade discursiva, conferindo-lhe, dessa forma, identidade e, também, capacidade de interpretação e produção de sentidos.

Ao passar por essa brevíssima história das abordagens da Educação Internacional e Comparada, percebe-se que, embora não se possa falar de evolução ou de linearidade, há uma tendência que perpassa todas as perspectivas apresentadas. É possível notar que a definição geográfica do objeto de estudo da EIC esvaiu-se com o passar do tempo. Dessa maneira, o Estado-nação, unidade clássica de análise do campo e que era absolutamente claro nos primórdios da EIC, tem hoje um outro modo de abordagem que não necessariamente coincide com a ideia de um lugar geograficamente circunscrito e que é, digamos, localizável no mapa. Esse tipo de abordagem, por conseguinte, abriu espaço para novas formas de constituição do objeto de estudo no campo dos estudos comparados em educação, como, por exemplo o cubo de Bray e Thomas (1995), publicado inicialmente num trabalho cujo título é Levels of Comparison in Educational Studies: Different Insights from Different Literatures and the Value of Multilevel Analyses.

Dessa forma,

Um ponto que foi enfatizado mais do que qualquer outro no artigo de Bray e Thomas foi seu apelo para que as análises em estudos comparativos fossem conduzidas em múltiplos níveis para torná-las mais holísticas e multifacetadas. Os autores notaram que grande parte das pesquisas se restringia a um só nível, negligenciando, desta forma, como os padrões existentes nos níveis acima deles e vice-versa. Embora seja verdade que, frequentemente, o pesquisador apenas pode conduzir seus estudos num só nível, devido a restrições de finalidade e de disponibilidade de recursos, Bray e Thomas sugeriram que os pesquisadores deveriam, pelo menos, reconhecer formalmente as limitações das suas focalizações e a influência mútua de outros níveis sobre os fenômenos educacionais alvos do seu interesse. (BRAY, 2015, p. 37)

A partir da reflexão sobre o cubo, observa-se que embora o estudo possa estar focado nos países ou em regiões maiores (União Europeia, Mercosul ou outra forma de categorização) a combinação dos diversos níveis faz com que o objeto de estudo não seja mais um bloco homogêneo e, ainda que se estude os sistemas de ensino, este já não são fixos, mas parte do processo de reflexão na construção da comparação. Localizar a pesquisa no cubo é importante justamente por ser uma tarefa prévia ao ato de comparar propriamente disto, pois se trata de visualizar a pesquisa nos diversos níveis a fim de definir como articular os diversos saberes no momento mesmo da comparação. 
Assim, a abertura no campo da Educação Internacional e Comparada não se dá somente em termos teóricos e metodológicos, mas também em relação ao seu objeto de estudo. Ao tratar da Educação Internacional e Comparada (EIC), Amaral (2015) mostra as dificuldades na definição da EIC se tomarmos como parâmetro o objeto de estudo. Segundo ele,

Há também certa dificuldade em se definir precisamente a EIC também em relação a seus objetos de pesquisa. [...] os objetos de estudo da EIC incluem potencialmente todos os aspectos da educação, de sorte que não se deixa definir, como outras subdisciplinas da educação, com base em grupos ou faixas etárias (como a educação de jovens e adultos), por uma perspectiva social (Pedagogia Social) ou histórica (História da Educação). No campo da EIC convencionou-se a distinção dos inúmeros objetos de estudo por meio de diferentes níveis ou categorias analíticas utilizadas para definir objetos de pesquisa. Quatro níveis podem ser identificados: substantivo ou temático; geográfico ou espacial; temporal sincrônico ou diacrônico; e/ou demográfico. (p. 259)

Vale destacar que a perspectiva acima apresentada acrescenta, em relação ao cubo, o nível temporal sincrônico ou diacrônico. É importante, na abordagem temporal considerar que não se trata de ver o tempo como um fluxo constante ou como um conceito linear, mas são processos complexos profundamente relacionados com o próprio movimento da história, fazendo com que a ideia de uma seta representando o tempo seja, nessa perspectiva, substituída pela imagem de uma rede, em que se pode fazer o movimento constante de ir e vir na teia construída. Assim,

These methodological approaches attempt to define concepts of space and time in a non-linear way, enabling comparative research to free itself from traditional notions of place (those that usually have to do with the nationstate) and time (a concept that usually would refer to linear time chronology placed in the Western-modern history) ${ }^{2}$. (NÓVOA; YARIV-MASHAL, p. 434, 2003)

Percebe-se, a partir dessa discussão, que o campo da Educação Internacional e Comparada tem se configurado como um campo explicitamente aberto e, de forma mais profunda, tal característica tem feito o campo mais forte em suas propostas de comparação. Nesse sentido,

Embora a inexistência de uma unidade disciplinar tenha sido por muito tempo interpretada como motivo de recorrentes crises identitárias da EIC

2 Essas abordagens metodológicas tentam definir conceitos de espaço e tempo de uma forma não-linear, possibilitando à pesquisa comparada livrar-se das noções tradicionais de lugar (aquelas que usualmente têm a ver com o estado-nação) e tempo (um conceito que usualmente se referiria ao tempo cronológico ligar situado na história ocidental moderna). (Tradução nossa) 
(Kelly, Altbach; Arnove, 1982, p. 509; Kazamias, 2012), a partir dos anos 1990, se tornou cada vez mais difícil manter qualquer ortodoxia teóricometodológica e, como escreveu Paulston (1993), o campo passou para uma heterodoxia mais pluralista e mais confortável em relação à diversidade epistêmica e metodológica. O controverso debate metodológico que dominou a EIC por quase 30 anos provou ser extremamente improdutivo academicamente, de modo que sua pluralidade epistemológica $\mathrm{e}$ metodológica - que se pode ver como uma de suas especificidades como campo acadêmico - mostra-se como elemento constitutivo. (p. 262)

Portanto, a Educação Internacional e Comparada tem em sua essência a não "ortodoxia teórico-metodológica" como eixo central. Tal concepção é fundamental e traz consequências drásticas para o campo, pois, ao assumir-se um campo aberto, precisa estar cada vez mais ancorada em referenciais teórico-metodológicos consistentes para que as análises não sejam meros apontamentos de semelhanças e diferenças. Assim, a questão não é mais se a EIC tem ou não uma unidade teórico-metodológica, mas como se dá esse processo nos mais diferentes níveis de comparação.

Antes de responder como ocorre a comparação, tendo em vista a abertura do campo da Educação Internacional e Comparada nos seus mais diversos níveis, é preciso diferenciar o ato comparativo a partir de duas perspectivas. Na primeira, temos que a comparação é um ato mental (BONITATIBUS, 1989) e, na outra, que comparar é um método científico social, conforme nos apresenta Schriewer (2009):

É preciso saber diferenciar, então, as operações que fixam os objetos de comparação como tais em sua conexão um com outro (em relação apenas com seus aspectos factuais) daquelas operações que concernem às conexões entre diferentes áreas de estudo ou níveis sistêmicos e com a definição destes em relação um com o outro. É esta diferenciação entre técnicas comparadas "simples" e "complexas" - ou, como formulado mais apropriadamente, entre "relações instituídas entre fatos observáveis" e "relações instituídas entre conexões" - que determina a diferença entre a comparação como uma operação mental universal embutida na vida social cotidiana e a comparação como um método científico social. (p. 67) - Grifos do autor.

A comparação deixa de ser uma estratégia intermediária para se chegar ao conhecimento e se torna o fio condutor na produção do conhecimento. Assim, o ato de comparar não é entendido somente como um recurso, mas como a essência da construção do saber no campo da EIC. Schriewer (2009) estabelece dois tipos de relação. No primeiro caso, a comparação enquanto operação mental universal, está na ordem das "relações instituídas entre fatos observáveis", isto é, o cérebro processo o que se apresenta e estabelece um paralelismo entre as informações, construindo, dessa maneira, um quadro comparativo, mas 
num nível apenas relacional. Num segundo momento, o autor destaca que a comparação como método científico social, está diretamente relacionada a "relações instituídas entre conexões", ou seja, trata-se de um movimento que ultrapassa o simples ato comparativo, que, aqui, comporta-se como o caminho pelo qual as conexões podem ser estabelecidas e, portanto, passíveis de serem relacionadas entre si.

Dessa maneira, a Educação Internacional e Comparada tem no seu funcionamento os dois movimentos citados e essa é justamente a característica que a define como um campo do saber específico. Em outras palavras, a comparação não é uma operação exclusiva do campo da EIC, entretanto, devido ao seu aparato teórico-metodológico, é possível passar para o segundo movimento, isto é, o estabelecimento de relações entre as conexões, resultado de uma comparação. Trata-se, entretanto, de um tênue limite entre uma simples operação mental, que também estabelece conexões - estratégia que não exige qualquer sustentação teórica ou metodológica - e a comparação elemento central da pesquisa, intencionalmente pensada no processo de compreensão do objeto de estudo e, portanto, necessariamente regida por um referencial teórico-metodológico que lhe confere a capacidade de ver as relações entre as conexões. Em resumo: a Educação Internacional e Comparada não somente estabelece as conexões, mas as relaciona e lhes confere sentido.

Nesse sentido, Weller (2016) afirma que

Enquanto método de interpretação, a comparação não objetiva apenas a análise contrastiva de dados empíricos, mas, sobretudo, a aprendizagem com e sobre o outro. Como princípio de entendimento, a comparação possibilita o reconhecimento de diferenças culturais existentes nas sociedades pluriétnicas que caracterizam grande parte dos estados nacionais contemporâneos assim como uma maior capacidade de compreensão das relações entre indivíduos e nações em suas especificidades. (p. 17) - Grifos da autora.

A autora, neste excerto, confirma que nos estudos comparados há a presença dos dois movimentos já apresentados, pois afirma que "a comparação não objetiva apenas a análise contrastiva de dados empíricos", ou seja, é, obviamente, passo decisivo num estudo comparado o contraste entre dados. Entretanto, não é apenas este seu objetivo. É necessário ir além e compreender como se ligam as relações entre as conexões estabelecidas no momento do estabelecimento do contraste inicial dos dados. A consequência desses movimentos é a possibilidade de aprendizado com e sobre o outro.

Vê-se, a partir dessa discussão, que a comparação, embora seja evidentemente o fio condutor de um estudo comparativo, não é, contudo, o primeiro ato nesse processo. Neste 
momento, cabe uma reflexão acerca de como um comparatista chega aos movimentos apresentados anteriormente, uma vez que os estudos comparados não são somente o contraste de dados, mas um procedimento reflexivo por parte do pesquisador. Nesse sentido, o debate proposto por Weller (2016) incita o questionamento acerca do que poderíamos chamar de movimento zero da comparação, isto é, o passo que antecede o ato comparativo propriamente dito, conforme afirma Bonitatibus (1989):

É no domínio da ação, da aplicação empírica do método, que os problemas se colocam, de vez que, para se efetivar, a comparação exige do analista certas decisões que devem ser tomadas antes mesmo de o trabalho ser iniciado. Tais decisões referem-se às "dimensões" que o processo de investigação comparativa assumirá. (p. 4) - Aspas da autora.

A autora propõe três dimensões no processo de investigação comparativa: temporal, espacial, metodológica (BONITATIBUS, 1989, p. 4, 5, 6). É preciso, assim, ter em mente o que se quer comparar e, de forma mais complexa, quais aspectos se quer comparar. Trata-se de uma reflexão crucial para a pesquisa e deve fazer parte do processo desde a escolha do objeto de estudo, até o momento mesmo da comparação. Nesse ponto, retoma-se o que Weller (2016) afirma sobre os impactos dos estudos comparados, isto é, a aprendizagem acerca do outro e de si mesmo. Tal resultado só é possível se a aplicação empírica do método comparado seja rigorosamente pensado em termos de um percurso reflexivo para, dessa maneira, escapar ao máximo da comparação como mero contraste de dados.

De forma bem reduzida, poder-se-ia delinear da seguinte maneira o método comparativo em educação:

- Movimento 0: reflexão acerca do objeto de estudo e, nesse processo, definição da dimensão (BONITATIBUS, 1989) ou dos níveis a serem comparados (BRAY \& THOMAS, 1995).

- Movimento 1: contraste dos dados empíricos, que podem ser textos, entrevistas, documentos (BONITATIBUS, 1989; SCHRIEWER, 2009)

- Movimento 2: estabelecimento de relações entre conexões (SCHRIEWER, 2009).

MÉTODO COMPARATIVO APLICADO À EDUCAÇÃO

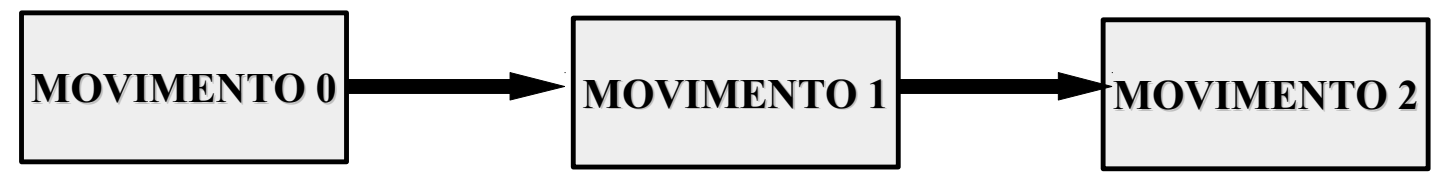


$\mathrm{Na}$ aplicação do referido método ${ }^{3}$, é importante também refletir acerca do potencial de comparação do objeto de pesquisa. Podemos situar essa etapa na passagem do Movimento 0 para o Movimento 1. Assim, é preciso questionar o objeto de estudo, levando-o aos seus limites em termos de comparação. Nesse movimento, é preciso que os dados não sejam subestimados nem tampouco superestimados. Nesse sentido, Saviani (2001) desenvolveu um estudo filológico no qual questiona “O que significa comparar?”, buscando o significado na própria língua portuguesa e, além disso, extrapolando para o latim e para o grego. Nesta pesquisa, o autor afirma que um dos significados do verbo comparar, considerando a origem grega da palavra, está ligado ao termo sincretismo, isto é, juntar elementos que não necessariamente possuem relação entre si ou até mesmo são contraditórios (SAVIANI, 2001, p. 6-7). Esse tipo de estudo, portanto,

[...] nos permite compreender a comparação como procedimento intelectual caracterizado por um potencial crítico mas que, ao mesmo tempo, traz consigo o risco de juntar elementos não suscetíveis de serem reunidos efetuando aproximações indevidas (SAVIANI, 2001, p. 7) - Grifos do autor.

Diante desse quadro, como seria possível produzir comparações de elementos que, à primeira vista são absolutamente diferentes? A única saída viável é, sem dúvida, relacionar educação e sociedade, numa perspectiva em que os fatos educativos não sejam considerados alheios ao funcionamento da sociedade como um todo. Assim, o contexto (histórico, político, social, econômico, temporal, espacial) assume uma posição central em um estudo comparado pois

[...] seja qual for a perspectiva analítica que se adote, o estudo do sistema educacional como um todo, ou delimitado a certos níveis, graus, tipos, ramos, aspectos ou problemas, o fato é que jamais poderemos pensá-lo como se existisse num vácuo social. Não faria o menor sentido "pinçarmos" sistemas educacionais, desvinculando-os de seus contextos sociais mais amplos, a fim de estudá-los comparativamente. O sistema educacional é um subsistema social e, nessa medida, inexiste enquanto unidade independente. Sua apreensão, compreensão e interpretação só podem ganhar significado quando referenciadas ao conjunto da vida social, esta sim a unidade integradora e definidora da ação educativa. (BONITATIBUS, 1989, p. 9)

Um sistema educacional (ou qualquer outra unidade a ser comparada) é, como define a autora, um "subsistema social" e, portanto, seu processo de identificação está intimamente atrelado ao contexto social no qual está inserido Nesse tipo de análise, a

3 Obviamente, há outros passos no método comparativo aplicação à educação. Trata-se, neste momento, apenas de um esquema básico para, no decorrer do estudo, ir ampliando os movimentos a fim de contemplar a complexidade inerente ao método comparativo. 
pedagogia, por si só, não é capaz de produzir interpretações que abarquem a complexidade dos fenômenos educacionais que, portanto, só podem ser apreendidos por meio da interação entre os mais diversos campos do saber. Tal característica é, como já mostrado, a essência da Educação Internacional e Comparada.

Um outro aspecto que Bonitatibus (1989) destaca é que independentemente da perspectiva analítica e metodológica adotada, um estudo comparado em educação não pode escapar da relação simbiótica entre educação e sociedade ou, colocando em termos técnicos, a educação não tem sentido se pensada para fora do contexto social que a define e, dessa forma, a interpretação de um fato educativo produzida a partir de um estudo comparado que considere o universo da educação por ele mesmo está, inevitavelmente condenado à inconsistência, pois não se estaria sendo fiel à origem dos dados, isto é, da gênese social (política, econômica, filosófica) dos fatos educativos.

Três pontos relacionados entre si são cruciais nessa discussão. Primeiramente, surge um debate acerca do papel do outro na Educação Internacional e Comparada e, como consequência, a discussão da ética nos estudos comparados se torna uma das questões centrais, na medida em que a forma como o pesquisador se relaciona com o outro - essência da EIC - e, consequentemente, como serão administrados os dados produzidos ou coletados na pesquisa. Além disso, um terceiro ponto, a definição do conceito de contexto que, de certa forma, é anterior aos outros mencionados, também emerge nesse processo.

Começando de trás para frente, isto é, a partir da noção de contexto, percebe-se que no início da EIC não havia nenhuma dificuldade com esse conceito, na medida em que os Estados-nação eram unidades claras e objetivas de modo que contextualizar um estudo comparado não era uma tarefa complicada pois as variáveis envolvidas no ato comparativo eram, de certa forma, reduzidas. Se pensarmos no desenvolvimento do campo da Educação Internacional e Comparada, sobretudo a partir da segunda metade do século XX, o processo de globalização trouxe muitas outras variáveis para a realidade educacional que tiveram severas implicações nos estudos comparados. A partir daí, a noção de contexto torna-se extremamente fluida, principalmente se considerarmos os grandes blocos econômicos como a União Europeia, redefinindo, assim, a própria definição de nação. Portanto, definir com precisão o contexto de um estudo comparado num mundo em que as fronteiras já não são mais explícitas, tornou-se tarefa extremamente complexa para o pesquisador. $\mathrm{O}$ que não 
mudou, contudo, é o fato de que ainda é necessário que se defina o contexto da comparação sob risco de ter a interpretação dos fatos educativos comprometida.

No que se refere à noção de contexto, Amaral (2015) traz a seguinte argumentação:

[...] as discussões sobre globalização dos últimos anos contribuíram amplamente para o questionamento e a desestabilização da unidade de comparação vista tradicionalmente como singular na EIC - o Estado-nação. [...] O uso dessa unidade como contexto capaz de explicar o que acontece no campo da educação levou a uma situação na qual o nível nacional é visto como contexto (mais ou menos) independente do restante do nosso mundo social. O que se conta como contexto reflete e, ao mesmo tempo, reproduz a suposição de que tudo que ocorre de importante no sistema nacional de educação é resultado exclusivo de atividades no âmbito do respectivo sistema nacional. Aqui o nacionalismo metodológico nos limita a procurar as causas e as respostas para problemas educacionais mais ou menos exclusivamente no âmbito nacional. [...] Desse modo, a globalização tem mudado a natureza e a importância do que se entende como contexto [...]. [...] a globalização se torna então o contexto dos contextos [...]. (p. 270271)

Assim sendo, o fato de o processo de globalização ter trazido mais fluidez às fronteiras nacionais (principalmente com o advento da internet, que fez o mundo ficar cada vez “menor”) não elimina a necessidade de definição de um contexto. Pelo contrário, a maior fragmentação dos países e dos modos de vida fazem com que seja ainda mais premente a necessidade de tratar essa noção com mais rigor. O autor nos apresenta, nesse sentido, que a globalização seria "o contexto dos contextos", isto é, torna-se a unidade a partir da qual os contextos específicos são definidos. Importante observar que o fato de ser um contexto mais amplo não traz, necessariamente, supremacia para a globalização, no sentido de importância, mas mostra de forma mais explícita que a relação entre contextos se dá a partir de uma via de mão dupla em que o local influencia o global e vice-versa. Portanto, ainda que seja um contexto muito particular, ele faz parte do contexto maior denominado globalização e, portanto, exerce influência tanto quanto é capaz de influenciar o contexto mais amplo, conforme afirma Bauman (2011, p. 77): “Seja qual for o sentido de 'globalização', ela significa que somos todos dependentes uns dos outros. Distâncias importam pouco, agora. Qualquer coisa que ocorra localmente pode ter consequências globais". O pesquisador comparatista deve, assim, ser capaz de transitar nessa tensão entre local e global para não pôr em evidência um e subestimar o outro ou o contrário. É preciso, para uma comparação metodologicamente bem sustentada, que não se apague a tensão entre o contexto específico e 
o contexto amplo, pois essa relação está na base da construção de sentidos e deve ser levada em conta na pesquisa comparativa.

Nessa discussão a respeito do contexto e sua fragmentação, não é possível ir adiante sem, contudo, problematizar a perspectiva, na Educação Internacional e Comparada, do Outro e, consequentemente, da ética no relacionamento do pesquisador comparatista com esse outro que se apresenta no processo comparativo. É preciso, inicialmente, dizer que "O outro é a razão de ser da Educação Internacional e Comparada: o outro que serve de modelo ou de referência, que legitima as ações ou que impõe silêncios, que se imita ou se coloniza". (NÓVOA, 2009, p. 24). Dessa forma, o encontro de um “eu” com um “outro" é inevitável no campo da EIC e, por isso, questionar o estatuto dessa relação é fundamental para se estabelecer os limites da comparação pois, de outro modo, poder-se-ia ultrapassar fronteiras que, em muitos casos, não estão explícitas mas que funcionam de forma sistemática e que cabe ao pesquisador explorar tais limites a fim de respeitá-los.

Há que se destacar, ainda, que o Outro na Educação Internacional e Comparada não é necessariamente um indivíduo, mas pode ser um país, uma escola, documentos, textos de um modo geral. Portanto, tratam-se, na verdade, dos dados de pesquisa, que não devem, contudo, ser tratados de qualquer modo, mas, de forma prudente, deve-se compreender seus limites e que, nesse relacionamento, há fronteiras éticas que devem estar bem marcadas, pois, embora o contato imediato seja, muitas vezes, somente com um texto escrito, não se pode perder de vista que se trata, antes de mais nada, de algo produzido por pessoas em sociedade e, dessa maneira, ainda que a pesquisa comparativa não envolva pessoas diretamente, trás sempre sua presença por intermédio dos textos, documentos, leis, etc.

A esse respeito, é preciso destacar que o Outro tem sido objeto de discussão no campo da Educação Internacional e Comparada, conforme nos apresenta Malet (2004):

[...] o discurso comparatista, ao mesmo título que o discurso antropológico, tem ignorado o Outro, fazendo dele um objeto, muito mais frenquentemente do que tentou compreendê-lo. O conhecimento não pode mais ser, no presente, uma simples acumulação de informações sobre um "estrangeiro esquisito" (Valadier, 1997, p. 177), mas deve participar da "elaboração do conhecimento comum" (Augé, 1994, p. 78)" (p. 1319)

No trecho acima, o autor destaca os aspectos da presença constante do Outro no horizonte dos estudos comparados em educação, além do debate ético inerente ao relacionamento do pesquisador com o Outro. A problemática que se apresenta nesse debate é ao papel que o "eu" tem diante desse Outro, isto é, ou o pesquisador o encara como o mero 
objeto de pesquisa ou o integra no processo de comparação de modo a não ultrapassar os limites da interpretação do Outro. No caso de pesquisa que envolva diretamente a participação de pessoas, a relação tem de ser, sobretudo, pautada pelo respeito ao acesso, isto é, só é possível ir até onde o participante da pesquisa permitir. Quando o Outro aparecer sob a forma de um texto (documento, leis, manuais, livros, etc.), o limite possível é o próprio texto, ou seja, a interpretação produzida no processo de comparação não deve ir além do que informa o texto. Assim, como veremos mais adiante, ainda que se fale do não dito, este só é possível em face de algo que foi explicitamente colocado na materialidade do texto. Portanto, não se trata de procurar sentidos nas entrelinhas, mas de partir das palavras enquanto realidade material (ORLANDI, 1999).

O apagamento do Outro nos estudos comparados, apresentado por Malet (2004), pode ser considerado como parte do funcionamento desse mundo fragmentado que dá sentido às práticas, assim,

Os conceitos de responsabilidade e escolha responsável, que costumavam residir no campo semântico do dever ético e da preocupação moral com o Outro, se moveram ou foram deslocados para a esfera da autossatisfação e do cálculo de risco. Nesse processo, o Outro, como gatilho, alvo e medida de uma responsabilidade aceita, assumida e cumprida, quase desapareceu do horizonte, expulso a cotoveladas ou simplesmente ofuscado pelo self do próprio ator. "Responsabilidade" agora significa, do começo ao fim, responsabilidade para consigo mesmo [...] ao passo que "escolhas responsáveis" são, também de ponta a ponta, ações com um feitio tal que servem bem aos interesses e satisfazem os desejos do ator, além de evitar a necessidade de compromisso. (BAUMAN, 2011, p. 59)

A ética líquida da contemporaneidade descola o eixo da ética e da moral, trazendo para o centro do discurso o "eu" no lugar do Outro. Dessa forma, o discurso comparatista, na visão de Malet, traz para o centro um modo de operar a comparação que não considera o Outro como parte interessada no processo, por isso afirma que "faz dele um objeto", isto é, apenas mais um elemento da comparação. $\mathrm{Na}$ verdade, deveria ser visto como o centro do estudo comparado, pois se trata do contraponto necessário para a efetivação da comparação, como afirma Bonitatibus (1989): “É fato que, para comparar, necessitamos, no mínimo, de dois elementos. Nenhum confronto faria sentido se tomássemos um elemento único que, dessa forma, teria de ser comparado a si próprio" (p. 5). Portanto, a Educação Internacional e Comparada não pode se esquivar do debate, inclusive e principalmente, no decorrer da pesquisa pois há uma relação necessária para a existência da comparação e, consequentemente, da construção do próprio estudo comparativo. 


\section{2 - Análise de Discurso: possibilidades teórico-metodológicas para a Educação Internacional e Comparada}

Depois de mostrar a Educação Internacional e Comparada como um campo aberto desde suas origens, é preciso, a partir de agora, entender como tal característica pode, efetivamente tomar corpo nas pesquisas. Propomos, a partir deste estudo, uma articulação da Educação Internacional e Comparada com a Análise de Discurso (AD) francesa. Assim, mostraremos como a EIC pode ser articulada metodologicamente com a $\mathrm{AD}$, de modo que esta passa a ser o elemento que dá subsídios ao campo da pesquisa comparada em educação. Em outras palavras, a comparação, a partir desta perspectiva, é feita a partir da análise discursiva de textos relacionados ao campo da Educação. Na primeira seção, o foco foi mais nos aspectos epistemológicos do campo da EIC e, agora, trata-se da articulação teóricometodológica que movimenta a pesquisa.

O campo da Educação Internacional e Comparada, parte de um campo mais amplo, o da Educação, traz em seu cerne uma infinidade de elementos constitutivos, muitas vezes contraditórios entre si, que compõem um quadro extremamente complexo acerca dos pressupostos que sustentam as práticas tanto no campo mais amplo, quanto na própria EIC (BONITATIBUS, 1989). Assim,

É, justamente, a apreensão de tais elementos em conflito que buscamos nos estudos comparativos e é por esta razão que não podemos dispensar os conhecimentos advindos dos vários campos do saber. É, ainda, por todos estes motivos que insistimos na impossibilidade de delimitação a priori do campo de estudos da Educação Internacional e Comparada. Preferimos, a despeito de aumentar sua complexidade, encará-la, simplesmente, como uma "área interdisciplinar de estudos, reflexão e investigação educacional comparativa." (BONITATIBUS, 1989, p. 26)

Dessa maneira, não existe uma saída producente para a EIC que não seja articularse com outras áreas do saber, permitindo que esse outro campo venha suplantar o campo comparativo, mas, ao contrário, vem conferir-lhe um rumo metodológico capaz de responder aos anseios específicos de cada pesquisa. Fica claro, a partir dessa constatação, que não se trata de definir um modelo ou padrão metodológico para todas as pesquisas comparativas em educação, mas explorar de forma positiva essa abertura de modo a permitir comparações mais precisas sem, contudo, que os estudos sejam amplos de tal forma que a comparação se torne vaga ou mesmo sem sentido. O suporte de outras disciplinas é fundamental para que as 
especificidades de cada pesquisa sejam contempladas em sua plenitude e, assim, seja possível responder de forma mais precisa ao que é perguntado pelo pesquisador.

O próprio campo da EIC foi percebendo, sobretudo nos últimos 30 anos, que não seria possível manter um isolamento completo de outras áreas na medida em que essa característica é a própria essência da Educação Internacional e Comparada e, ao contrário de ser combatida, essa necessidade de integração com outras disciplinas se mostra a grande força do campo e, por isso, já não se procura unificar metodologias ou abordagens. No final da década de 1970, entretanto, já havia indícios de que o campo caminhava para uma abertura mais consolidada com relação à constituição metodológica.

O campo não tem um só método de estudo; em vez disto é cada vez mais tipificado por várias orientações de pesquisa diferentes. Não há mais nenhum esforço sendo envidado para definir uma metodologia única para a Educação Comparada e nenhum dos nossos colaboradores defende o desenvolvimento de um método único normatizado para o campo. (ALTBACH; KELLY, 1986, p.1)

No caso específico deste estudo, a articulação com a Análise de Discurso se justifica por dois motivos. O primeiro deles se refere à minha formação na área de Letras, o que fez do estudo da Linguística algo muito presente na prática docente e de pesquisa, especificamente a AD. A segunda razão pela escolha dessa teoria do discurso está ligada ao fato de que, sobretudo na abordagem hermenêutica, os fenômenos educacionais passam a ser visto dentro de práticas discursivas e, portanto, o estudo dos modos como se dá a construção e circulação de sentidos, tanto na Educação quanto na Educação Internacional e Comparada, mostra-se como importante passo na compreensão do fatos educativos de forma a abarcar toda a complexidade do campo.

Um outro aspecto importante na definição da Análise de Discurso francesa como elemento articulador da EIC reside no fato de que a perspectiva histórico-hermenêutica na Educação Internacional e Comparada preconiza o discurso como elemento central na comparação. Nóvoa (2009), citado anteriormente, aponta para o fato de que as fronteiras não são mais geográficas e sim discursivas. Os sujeitos já não têm como unidade de organização básica o país enquanto espaço restrito, mas se agrupam a partir de comunidades discursivas. Nesse sentido,

Desconfiando das ideologias progressistas e exógenas que, por muito tempo, trabalharam o campo, essa tendência contemporânea substitui progressivamente um modelo contextual e pragmático por um modelo 
textual que traduz a centralidade do discurso na construção dos fenômenos educativos. (MALET, 2004, p. 1316)

Assim, a análise discursiva assume posição de destaque nesse tipo de abordagem de modo que as práticas educacionais são compreendidas como movimentos de linguagem e não mais como práticas puramente empíricas. Entretanto, é necessário que os fatos de educação sejam interpretados como elementos simbólicos, que têm impacto na vida concreta das pessoas, mas que se constitui na/pela linguagem. Nessa construção de interpretações dos fatos educacionais enquanto discurso, a $\mathrm{AD}$ procura

Problematizar as maneiras de ler, levar o sujeito falante ou o leitor a se colocarem questões sobre o que produzem e o que ouvem nas diferentes manifestações da linguagem. [...] Saber que não há neutralidade nem mesmo no uso mais aparentemente cotidiano dos signos. A entrada no simbólico é irremediável e permanente: estamos comprometidos com os sentidos e o político. Não temos como não interpretar. Isso, que é contribuição da análise de discurso, nos coloca em estado de reflexão e, sem cairmos na ilusão de sermos conscientes de tudo, permite-nos ao menos sermos capazes de uma relação menos ingênua com a linguagem. (ORLANDI, 1999, p. 09)

Começando pela última frase, Orlandi (1999) coloca-nos diante da possibilidade “de uma relação menos ingênua com a linguagem". Trazendo para o campo da Educação Internacional e Comparada, essa articulação tem o propósito de estabelecer comparações menos ingênuas, isto é, que não se fique na superficialidade dos dados empíricos, mas, a partir deles, romper a evidência de sentidos, a obviedade da interpretação e uma leitura de mundo em que os sujeitos não sejam instados a "acreditar" no primeiro sentido que lhes aparece no momento da leitura de um texto, por exemplo, e sejam capazes de compreender que há um modo de funcionar da linguagem, dos discursos e isso tem de ser levado em consideração na interpretação. Essa visão se aproxima da que García (1993), ao tratar do pensamento de Karl Mannheim, destaca ao afirmar que "la insistencia [...] en la importancia dada al análisis del lenguaje y del cambio de las significaciones de las palabras como forma de investigación de cambios estructurales profundos en la evolución de una sociedad ${ }^{4 \%}$ (p. 66). Reforça, dessa maneira, que a apreensão do mundo se dá por intermédio da linguagem e somente assim.

Se o mundo interpretável é aquele da linguagem, a proposta é, a partir dos pressupostos da $\mathrm{AD}$, fazer com que ao ler, não o façamos de modo natural, como se a linguagem fosse transparente e os sentidos evidentes. A principal contribuição para a

4 “[...] a insistência na importância dada à análise da linguagem e da mudança das significações das palavras como forma de investigação de mudanças estruturais profundas na evolução de uma sociedade". (Tradução nossa) 
Educação Internacional e Comparada, nesse sentido, é evidenciar o processo de construção das comparações, destacando que se trata de linguagem e não de relações naturais.

Tendo esses aspectos em mente, abordaremos o método da Análise do Discurso de forma esquemática para, quando formos analisar os textos nos capítulos 2 e 3, possamos, de fato, articular outros conceitos dentro do campo discursivo. Aqui, portanto, serão apresentados apenas os pressupostos mais gerais da $\mathrm{AD}$ que sustentarão as análises e, nos capítulos subsequentes, mobilizaremos outros conceitos mais específicos para cada situação a ser analisada. Além disso, no final desta seção, faremos uma articulação conceitual da Análise de Discurso com a Educação Internacional e Comparada e, no decorrer das análises dos textos das reportagens, trabalharemos a articulação numa perspectiva mais prática, mostrando como teoria e metodologia devem estar equilibradas.

A AD é uma disciplina de entremeio, constituída a partir da Linguística de Saussure (2006), com a noção de que a língua tem sua ordem própria; o Materialismo Histórico, com a ideia de que é na história que se produzem os sentidos e, assim, tem-se a língua fazendo sentido na história, não como um elemento abstrato, mas em sua forma material; e a Psicanálise, com o deslocamento da noção de pessoa empírica para sujeito que, por sua vez, é constituída na história (cf. ORLANDI, 1999, p. 19).

Nesse aspecto, a Análise de Discurso diferencia-se essencialmente da Análise de Conteúdo, não no sentido de estabelecer diferenças de grau, mas de categoria, isto é, a $\mathrm{AD}$ não é melhor que a Análise de Conteúdo, apenas responde a perguntas diferentes e se constitui a partir de caminhos diferentes. Essencialmente,

[...] a Análise de Discurso considera que a linguagem não é transparente. Desse modo ela não procura atravessar o texto para encontrar um sentido do outro lado. A questão que ela coloca é: como este texto significa? Há aí um deslocamento (...) onde a questão a ser respondida não é "o quê" mas o "como". Para responder, ela não trabalha com os textos apenas como ilustração ou como documento de algo que já está sabido em outro lugar e que o texto exemplifica. Ela produz um conhecimento a partir do próprio texto, porque o vê como tendo uma materialidade simbólica própria e significativa, como tendo uma espessura semântica: ela o concebe em sua discursividade." (ORLANDI, 1999, p. 17-18)

Por isso, expressões como "nas entrelinhas do texto" ou "por trás do que se disse" não cabem na $\mathrm{AD}$ na medida em que pressupõem sentidos já estabelecidos e que estão em algum lugar onde o analista deve chegar para os encontrar e, apenas, revelá-los. Portanto, não existem sentidos nas entrelinhas pois é a materialidade do texto que interessa ao analista, isto 
é o que está dito, da forma como está dito. É a partir daí que se pode trabalhar conceitos como não dito, pois está em relação a algo que está dito no texto.

Dessa forma, três conceitos são centrais para a Análise de Discurso: as noções de ideologia, de sujeito e de Formação Discursiva (FD). Estão intimamente ligados entre si, mas possuem especificidades que precisam ficar claras pois esses conceitos são a base do processo analítico e, além disso, são elementos fundamentais que diferenciam a AD francesa da Análise de Discurso Crítica (ADC).

Primeiramente, trataremos do conceito de ideologia, um dos centros conceituais da Análise de Discurso francesa pois Pêcheux (1995) não a define sob uma perspectiva sociológica, mas a partir da linguagem. Para a $\mathrm{AD}$, diferentemente da forma que comumente é concebida, a ideologia não é ocultação da realidade, visão de mundo ou conjunto de representações, mas está ligada à interpretação, estabelecendo, dessa maneira, a relação necessária entre sujeito/língua/história de modo que seja possível haver sentido(s) (cf. ORLANDI, 1999, p. 48). A partir dessas considerações, temos que

Enquanto prática significante, a ideologia aparece como efeito da relação necessária do sujeito com a língua e com a história para que haja sentido. E como não há uma relação termo a termo entre linguagem/mundo/pensamento essa relação se torna possível porque a ideologia intervém com seu modo de funcionamento imaginário. São assim as imagens que permitem que as palavras "colem" com as coisas. Por outro lado, como dissemos, é também a ideologia que faz com que haja sujeitos. O efeito ideológico elementar é a constituição do sujeito. Pela interpelação ideológica do indivíduo em sujeito inaugura-se a discursividade. Por seu lado, a interpelação do indivíduo em sujeito pela ideologia traz necessariamente o apagamento da inscrição da língua na história para que ela signifique produzindo o efeito de evidência do sentido (o sentido-lá) e a impressão do sujeito ser a origem do que diz. Efeitos que trabalham, ambos, a ilusão da transparência da linguagem. No entanto, nem a linguagem, nem os sentidos nem os sujeitos são transparentes: eles têm sua materialidade e se constituem em processos em que a língua, a história e a ideologia concorrem conjuntamente. (ORLANDI, 1999, p. 48)

Definida dessa forma, a ideologia, na $\mathrm{AD}$, não pode ser considerada boa ou má, nem exclusividade daqueles que estão em posições hierarquicamente superiores na sociedade e oprimem os mais fracos. Trata-se de uma outra perspectiva na qual a ideologia (no singular) é parte essencial do funcionamento discursivo. No processo de construção dos sentidos, é a ideologia que faz a relação palavra/mundo parecer natural, isto é, como se as palavras estivessem atreladas ao mundo diretamente. Esse é precisamente o trabalho da ideologia, fazer com a relação linguagem/mundo/pensamento seja evidente, natural. A partir desse 
trabalho da ideologia, temos sempre a sensação de que as palavras possuem significados nelas mesmas e, além disso, sempre os mesmos significados. Pode-se dizer, a partir disso, que a função essencial da ideologia é produzir evidências, vale dizer, em todos as formas do dizer. Significa, portanto, que mesmo os dizeres mais banais, cotidianos são afetados por esse funcionamento ideológico. Dessa maneira, não existe inocência na linguagem e os sentidos, constantemente, são alvos de tentativas de domesticação, direcionamento, antecipação e toda sorte de controle por parte dos sujeitos.

Esse é um conceito que precisa ficar muito bem delimitado pois é um dos pontos fortes que definem a Análise de Discurso francesa teórica e metodologicamente. Já que este é um estudo comparativo, é fundamental compreendermos o lugar da $\mathrm{AD}$ francesa em relação a outros tipos de análises discursivas, nomeadamente a Análise de Discurso Crítica. Nela, a noção de ideologia caminha em sentido contrário ao que propomos nesta pesquisa. Trata-se, para a ADC, da ideia de "desvelamento de ideologias" (cf. FAIRCLOUGH, 2001; RAMALHO \& RESENDE, 2011; RESENDE \& RAMALHO, 2006; RESENDE, 2009a, 2009b), perpassando uma noção negativa da ideologia, isto é, como instrumento de dominação das classes mais poderosas. Nesse sentido, a ADC só considera ideológicos, os discursos que visão alguma forma de dominação.

De forma bem diferente, para a AD francesa, tanto os discursos dos "dominantes" quanto os dos "dominados" são necessariamente ideológicos, na medida em que não há interpretação sem ideologia, isto é, sem que os sentidos sejam "colados" às palavras, criando a evidência de que existe relação natural entre as palavras e o mundo. É a ideologia que cumpre o papel de fazer com que essa relação, que é histórica, se torne evidente, como se sempre tivesse sido assim. A ideologia, portanto, realiza um jogo de memória e esquecimento no discurso, de modo que se apaga o processo histórico de construção dos sentidos, fazendo com que sejam considerandos como transparentes para o sujeito leitor/ouvinte/falante.

Tal funcionamento é baseado a partir de imagens (de professor, de aluno, de colonizador, de patrão, de mulher, de marido, de filho etc.) que são "coladas" no discurso, fazendo com que pareça que sabemos exatamente sobre o que estamos falando. Dessa maneira, é como se todos já soubessem de antemão o que significa ser um professor numa sociedade como a nossa, como se a imagem que se tem sobre o que é ser docente no Brasil

5 As aspas aqui se referem ao fato de que não são posições definidas a priori, pois pode-se ter sujeitos dominados falando como dominadores e vice-versa. Por exemplo: uma mulher com discurso machista, um negro com discurso racista, um país que foi colonizado falando como colonizador. 
fosse desde sempre conhecida pelos sujeitos falantes. Contrapondo, novamente, a ADC, o trabalho do analista, no caso da Análise de Discurso francesa, não é desvelar as ideologias, mas mostrar que os sentidos não são uma realidade dada, mas resultado de processo histórico, de contradições. Por isso, cabe ao analista situado na $\mathrm{AD}$ francesa remeter a língua à história, num processo que traga à tona o modo como se dá a constituição dos sentidos, isto é, a historicidade desse processo. Não se busca desvelar a ideologia nos discursos, mas seu modo de funcionamento, pois a questão não é qual ideologia se manifesta particularmente, e sim como a ideologia produz seus efeitos.

Demarcada essa diferença teórico-metodológica, a segunda etapa na discussão do funcionamento da ideologia na $\mathrm{AD}$ francesa refere-se à constituição do sujeito, outro conceito entendido de forma muito particular. O papel primordial da ideologia, nessa perspectiva, é também criar a ilusão de somos sujeitos desde sempre. Ao comentar a noção de sujeito apresentada por Althusser (1970), Pêcheux (1995, p. 153) afirma:

Como todas as evidências, inclusive aquelas que fazem com que uma palavra 'designe uma coisa' ou 'possua um significado' (portanto inclusas as evidências da 'transparência' da linguagem), a evidência de que vocês e eu somos sujeitos - e que isto não constitua um problema - é um efeito ideológico, o efeito ideológico elementar. (Itálicos do próprio autor)

Por essa visão, o indivíduo é interpelado em sujeito pela ideologia. Daí a evidência de somos sempre sujeitos - efeito ideológico elementar -, condição sem a qual não existe produção de sentidos. Nessa situação, o sujeito se coloca como origem do dizer e dos sentidos e o dizer é colocado como se o que é dito só pudesse ser feito de uma maneira e não de outra. Tal condição é assentada na ilusão da transparência da linguagem, isto é, como se os sentidos estivessem numa prateleira à espera do sujeito para escolher as melhores palavras, os melhores significados, de forma plenamente consciente.

Vê-se, assim, que a $\mathrm{AD}$ concebe que não é o indivíduo empírico que se posiciona no discurso, mas sujeitos que falam a partir de lugares no dizer. Portanto, as palavras, cujos sentidos não são constituídos a priori, "extraem” seus sentidos dessas posições. Disso decorre que a posição do sujeito é fundamental para a interpretação pois uma palavra dita por um professor tem um significado diferente da dita por um aluno (nem melhor nem pior, apenas diferente). Essa relação, contudo, não é tão simples quanto parece à primeira vista pois os sujeitos são intercambiáveis (cf. ORLANDI, 1999, p. 49) e, assim, não se tratam de processos lineares, mas de, muitas vezes, contradições, idas e vindas no dizer que o analista deve ser 
capaz de apreender no seu dispositivo de interpretação. Por isso é que podemos encontrar, por exemplo, o Brasil falando na posição de colonizador mesmo sendo um país que foi colonizado, lançando mão das mesmas estratégias discursivas que foram usadas pelo colonizador em relação ao próprio país. Somente remetendo as posições de sujeito à história é que se pode ter acesso ao seu processo de constituição.

O modo como o sujeito ocupa um lugar no discurso não lhe é plenamente acessível. Com essa afirmação, relacionamos os conceitos de ideologia, sujeito e inconsciente, pensado pela via psicanalítica (um dos braços epistemológicos da Análise de Discurso francesa), afirmando que o sujeito é parcialmente responsável pelo que diz, essencial para se compreender como os sentidos são produzidos. Assim, se de um lado, os sujeitos são capazes de produção de sentidos diferentes, rompendo com práticas cristalizadas, por outro lado, também são "falados" pelas posições de sujeito constituídas historicamente. Aqui está o ponto crucial para o analista do discurso, pois ele tem de ser capaz de romper com esse efeito de que o sujeito fala o que quer, quando quer, da forma que quer, mobiliza os sentidos que quer. $\mathrm{Na}$ perspectiva que aqui apresentamos, isso é parcialmente verdade. Nos discursos, há sempre dizeres que se repetem e outros que se deslocam e, de forma contraditória, há aqueles que se dizem inovadores, mas repetem o que sempre foi dito.

Esse efeito ideológico é explicado por Pêcheux (1995, p. 173) sob a forma de dois esquecimentos ${ }^{6}$.

Concordamos em chamar esquecimento $n^{\circ} 2$ ao "esquecimento" pelo qual
todo sujeito-falante "seleciona" no interior da formação discursiva que o
domina, isto é, no sistema de enunciados, formas e sequências que nela se
encontram em relação de paráfrase - um enunciado, forma ou sequência, e
não um outro, que, no entanto, está no campo daquilo que poderia
reformulá-lo na formação discursiva considerada. (Itálicos assinalados pelo
autor)

O esquecimento número dois é da ordem da enunciação e diz respeito ao fato de que, quando falamos, o fazemos de uma forma determinada e não de outra. Trata-se de um esquecimento semiconsciente e, nesse sentido, o sujeito-falante cria família parafrásticas , evidenciando, portanto, que o dizer sempre pode ser outro. Além disso, a autonomia relativa do sujeito em relação ao dizer permite que ele volte às sentenças, fazendo novas elaborações, procurando, dessa maneira, especificar o que se quer dizer. O efeito ideológico, neste caso, é a ilusão referencial, isto é, a ideia de que falamos o que queremos da forma (sintaxe) como

6 Apresentaremos o esquecimento número 2 antes do primeiro somente para seguir o padrão seguido por M. Pêcheux (1995) no texto original. 
queremos. Constitui-se, assim, uma relação de naturalidade entre a linguagem e o mundo, como se uma palavra, de fato, tivesse um correspondente no mundo. (cf. ORLANDI, 1999, p. 35). Por isso, o sujeito acredita que é capaz de expressar no dizer exatamente o que pensa acerca de algo, ainda que tenha de formular a sentenças das mais variadas formas. Se a cada mínima tentativa de elaboração de sentenças o sujeito não fosse afetado por esse efeito ideológico, o dizer seria plenamente controlado pelo sujeito e, dessa maneira, os sentidos também seriam totalmente controláveis, não deixando margem para interpretações diferentes daquela intencionada pelo sujeito-falante. É preciso, assim, que o sujeito "esqueça" que não é plenamente senhor do dizer para que seja capaz de produzir sentidos.

Em relação ao esquecimento número um, Pêcheux (1995) afirma:

Por outro lado apelamos para a noção de "sistema inconsciente" para caracterizar um outro "esquecimento", o esquecimento $n^{\circ} 1$, que dá conta do fato de que o sujeito-falante não pode, por definição, se encontrar no exterior da formação discursiva que o domina. (p. 173) - Itálicos assinalados pelo autor.

O esquecimento número um é chamado de esquecimento ideológico e é da instância do inconsciente. Faz com que o sujeito tenha a ilusão de ser origem do dizer, isto é, como se suas palavras não tivessem qualquer relação com discursos já proferidos ou escritos. Como consequência, ele imagina-se fundando sentidos, como se suas palavras estivessem sendo ditas pela primeira vez. Essa ilusão atua no processo de produção de sentidos, pois o sujeito se acha controlador desse movimento e, de forma iludida, acredita controlar o processo de significação, acreditando garantir que os sentidos "escolhidos" sejam apreendidos em sua totalidade, sem "ruído", pelo sujeito ouvinte/leitor (cf. ORLANDI, 1999, p. 35), como no diálogo entre Alice e Humpty Dumpty nas Aventuras de Alice no país das Maravilhas \& Através do espelho e o que Alice encontrou por lá: "Quando eu uso uma palavra", disse Humpty Dumpty num tom bastante desdenhoso, "ela significa exatamente o que quero que signifique: nem mais nem menos.” (CARROLL, 2010, p. 359) (Itálico assinalado pelo autor).

Dessa maneira, propõe-se um descentramento do sujeito, de uma posição de absoluto controle do mundo (sujeito moderno) para um sujeito apenas parcialmente capaz de dominar os sentidos. Isso, contudo, não é um defeito no funcionamento discursivo, mas, ao contrário, é condição necessária para a identificação do sujeito com o seu dizer, permitindo-o significar-se com o que diz para, assim, constituir-se enquanto sujeito (cf. ORLANDI, 1999, p. 36). 
Observa-se, porém, que ambos os tipos de esquecimento apontam para a noção de Formação Discursiva (FD), o terceiro conceito que abordaremos aqui e outro ponto crucial sem o qual a compreensão da teoria discursiva proposta pela $\mathrm{AD}$ fica comprometida. $\mathrm{Na}$ constituição da Análise de Discurso, Pêcheux (1995) faz referência a Foucault (2008) para definir FD. Em Arqueologia do saber, Foucault procura definir a noção de Formação Discursiva, sendo esse o ponto de parte da Análise de Discurso para trazer esse conceito para o interior da teoria discursiva. Trabalhemos inicialmente os pressupostos definidos por Foucault (2008) para, em seguida, abordar esse conceito a partir da perspectiva da AD francesa.

O capítulo de Arqueologia do saber, de 1969, que trata da definição de Formação Discursiva parte da premissa de que há enunciados que podem ser agrupados segundo alguma espécie de regularidade não evidente de imediato. A questão fundamental que o autor levanta aqui é entender o que é exatamente que nos permite afirmar que existe tal regularidade nos enunciados.

O que é, então, $a$ medicina, $a$ gramática, $a$ economia política? Será que não passam de um reagrupamento retrospectivo pelo qual as ciências contemporâneas se iludem sobre seu próprio passado? São formas que se instauraram definitivamente e se desenvolveram soberanamente através do tempo? Encobrem outras unidades? E que espécies de laços reconhecer validamente entre todos esses enunciados que formam, de um modo ao mesmo tempo familiar e insistente, uma massa enigmática? (FOUCAULT, 2008, p. 36)

$\mathrm{Na}$ busca por encontrar o fundamento da unidade desses enunciados, Foucault elabora quatro hipóteses na tentativa de definir $o$ elemento definidor de um campo, de uma área, de uma disciplina (cf. Foucault, 2008).

A primeira hipótese diz respeito ao objeto dos enunciados. Segundo este argumento, os discursos possuem formas diferentes, estão situados de forma dispersa no tempo, mas coincidem no tocante ao objeto sobre o qual se fala. De forma resumida, poderse-ia afirmar que um discurso pode ser situado no campo da medicina pois tem como objeto algo referente exclusivamente ao referido campo. Entretanto, Foucault observa que, ao analisar os discursos com mais profundidade, uma gama enorme de objetos é abordada nos enunciados e, mesmo assim, não fica nenhuma grande dúvida de que se trata de discursos sobre a medicina. Conclui, portanto, que o critério do objeto do enunciado não é o melhor parâmetro para se definir o elemento que garante a regularidade dos discursos. 
Foucault, em seguida, apresenta uma hipótese que diz respeito ao tipo da enunciação e ao seu encadeamento. $\mathrm{O}$ autor usa novamente como exemplo a medicina, mostrando que, a partir do momento em que o objeto dos enunciados deixou de ser o elemento central, um modo de escrever, caracterizado, sobretudo pela organização em série de enunciados descritivos. Mais uma vez, Foucault abandona uma hipótese sob o argumento de que a própria medicina sofreu - e vem sofrendo - profundas transformações com relação aos tipos de enunciados que a definem e, portanto, este não poderia ser o critério definidor da unidade enunciativa de um campo.

A terceira hipótese apresentada por Foucault está assentada na ideia de que um conjunto de conceitos garantiria a unidade enunciativa de um campo. O exemplo utilizado aqui é o do estudo da gramática. Ao longo da história diversos estudiosos definiram conceitos e noções que definiram o campo dos estudos gramaticais. Observa-se, porém, que o estudo dos diversos períodos nesse campo se mostram heterogêneos em termos conceituais e, em alguns casos, contraditórios entre si. Além disso, conceitos surgem e desaparecem ao longo do tempo o que, por si só, configura-se um impeditivo para se adotar o conceito como elemento fulcral da unidade enunciativa.

Por fim, a quarta hipótese defende que a regularidade nos enunciados se dá por meio da permanência de uma temática e por sua identidade. O que Foucault mostra aqui é que os temas vão e vêm, assumem nuances específicas, são abordados simultaneamente por dois tipos de discursos diferentes. Portanto, não se mostrar um balizador confiável para cravar definitivamente a permanência de uma temática como a característica mais importante para se definir o que tem de regular em um determinado enunciado.

Diante dessas tentativas de encontrar o que há de regular nos enunciados, Foucault define que, na verdade, o foco da análise deve estar não no que se repete, mas no que dispersa. Ele chamará de sistema de dispersão (cf. Foucault, 2008, p. 43). Assim, mais do que apontar as diferenças entre os enunciados ou inferir que perpassa todos, o sistema de dispersão permite trabalhar de forma mais apropriada com a fluidez dos objetos, dos tipos de enunciação, dos conceitos e da persistência de uma temática. Assim sendo,

No caso em que se puder descrever, entre um certo número de enunciados, semelhante sistema de dispersão, e no caso em que entre os objetos, os tipos de enunciação, os conceitos as escolhas temáticas, se puder definir uma regularidade (uma ordem, correlações, posições e funcionamentos, transformações), diremos, por convenção, que se trata de uma formação discursiva [...] (FOUCAULT, 2008, p. 43) - Itálicos assinalados pelo autor. 
O que Foucault conclui, no final é Formação Discursiva não deve ser vista como um conceito fechado, como se fosse um bloco homogêneo. $\mathrm{Na}$ verdade, a ordem, as correlações, posições, funcionamentos, transformações são a exceção nesse processo. $\mathrm{O}$ regular, segundo o autor, é a dispersão. Portanto, nas variações em torno das possibilidades levantadas seja em relação à temática, ao objeto ou a qualquer outro aspecto, as Formações Discursivas serão sempre heterogêneas, abertas, fluidas, serão sempre mutáveis sob qualquer condição.

É a partir dessa discussão que Pêcheux (1995) define Formação Discursiva no âmbito da Análise de Discurso. Dessa forma, embora uma FD não seja constituída de forma fechada, é a partir dela que é possível compreender como se constroem os sentidos, pois as palavras significam a partir das posições daqueles que as utilizam. Dessa forma, uma mesma palavra pode ter significados muito diferentes em função da Formação Discursiva à qual está filiada. Por isso, pode-se dizer que "A formação discursiva se define como aquilo que numa formação ideológica dada - ou seja, a partir de uma posição dada em uma conjuntura sóciohistórica dada - determina o que pode e deve ser dito" (ORLANDI, 1999, p. 43).

Por isso é que Pêcheux (1995) alerta, quando trata do esquecimento número um, que não é possível o sujeito estar fora da Formação Discursiva que o domina, pois, caso fosse possível, não haveria sentidos, na medida em que não existiria uma instância reguladora para a qual os discursos apontam para, assim, significarem. Do mesmo modo, as posições que o sujeito ocupa para produzir sentidos também é determinado pela FD à qual está filiado, podendo, assim, a partir da posição que ocupa produzir determinados significados e não outros.

Nesse sentido, o professor fala de um lugar que não é o do aluno e vice-versa, pois os processos históricos de constituição dessas posições foram diferentes tanto entre si quanto em relação à própria posição ao longo do tempo. A posição de professor em 2016 não é a mesma se olharmos 50 anos atrás ou em relação ao século 17. Por isso, remeter os discursos às Formações Discursivas é um dos papéis primordiais do analista, pois permite observar como os sujeitos produzem sentido, observando as condições de produção do discurso. Concretamente, a palavra avaliação não tem o mesmo significado para alunos e para professores, nem tampouco significa da mesma forma para todos os professores em todos os tempos, independentemente do lugar. São os processos sócio-históricos, a partir do trabalho 
da ideologia, que permitem aos sujeitos associar uma palavra a um significado e, assim, produzir sentidos e, nesse mesmo processo, constrói sua identidade.

O que sempre deve estar no horizonte do analista é o fato de que o funcionamento das Formações Discursivas não é, de modo algum, previsível e acabado. Portanto, não há estabilidade absoluta nem nos sentidos, nem nos sujeitos, nem na FD. Esse movimento é o que garante sentidos diferentes e, consequentemente, possibilidade de novas interpretações. Sem isso, estaríamos condenados a produzir sentidos em um sistema fechado de modo que o novo não teria espaço e, dessa forma, as relações sociais permaneceriam imutáveis ao longo da história.

Por isso, muito embora a Análise de Discurso francesa possua um caráter analítico, ao compreender como o sujeito significa o mundo e, ao mesmo tempo, constrói a significação em torno de sua identidade, permite, como já dito, que se façam leituras menos ingênuas do mundo, de modo que a compreensão do modo como os sujeitos assumem esta ou aquela posição no discurso e, além disso, como a ideologia trabalha a evidência de que tudo é porque é, abre um leque de possibilidades para o novo, para a mudança do que parece imutável, estável, cristalizado. O papel do analista, neste caso, é o de interpretar os discursos questionando como foram produzidos, quais as condições de produção e, assim, permitir que essa leitura promova algum tipo de mudança nos relacionamentos entre os sujeitos.

Nesse ponto, a Análise de Discurso se cruza com a Educação Internacional e Comparada de forma decisiva. Ao situar este estudo na perspectiva histórico-hermenêutica, conferimos ao discurso o protagonismo no processo de compreensão dos fenômenos educacionais, sobretudo a partir do que Nóvoa (2009) argumenta, como já citado, no sentido de que as fronteiras não são mais demarcadas hoje a partir de contornos geográficos, mas tendo como referência as práticas discursivas.

Assim, um dos modos de pensar como se dará essa articulação é a partir dos conceitos que ambas as disciplinas têm como essenciais. Esse foi o trabalho que fizemos até o presente momento em relação à Análise de Discurso e, a partir de agora, trataremos de alguns conceitos centrais da Educação Internacional e Comparada e como podemos pensá-los a partir das proposições da $\mathrm{AD}$. Escolhemos, assim, um tema muito caro à EIC: o outro, a partir do qual derivam os outros conceitos que compõem o campo da Educação Internacional e Comparada. 
O outro está no centro da Educação Internacional e Comparada (Nóvoa, 2009) e, como tal, precisa ser pensado, como já colocado anteriormente dentro de uma ética e uma moral próprias para o campo comparativo. Não há como fazer um estudo comparado sem, antes de tudo, entendermos como se dá o encontro do eu com o outro ou, pensando em outras possibilidades, o encontro do outro com um outro outro (quando, por exemplo, um brasileiro faz um estudo comparado entre escolas do japão e da China e este pesquisador não tem uma relação pessoal com nenhum dos países). Independente da configuração, é fundamental entender como se dá essa abordagem, essa aproximação. Nesse sentido, o professor Candido Alberto Gomes observa que

\footnotetext{
Ver-se no espelho pode ser doloroso. Fácil é contemplar-se e deslegitimar como não apropriados os conhecimentos dos outros: nada temos com eles, então, tratemos de nós. Esse mito serve para ocultar o medo de dissolver o precário eu no do outro. Contudo, só se desenvolve a identidade do eu em contato com os outros. Isolar-se é fenecer. (GOMES, 2015, p. 253)
}

O primeiro ponto a ser destacado é a tensão que surge no embate entre quem pesquisa e o outro, que perpassa os estudos comparados como um todo. Trata-se de um encontro que é inevitável na Educação Internacional e Comparada na medida em que, desde seu princípio, o encontro com o outro é a meta fundamental. Ressalta-se, entretanto, que num primeiro momento, a relação que se estabelecia era, essencialmente, de caráter pragmático, no sentido de que havia a busca pelo diferente para que se encontrassem soluções para problemas do $e u$, isto é, daquele que empreendia um estudo comparado. O que se nota, a partir dessa constatação, é que, já nos primórdios da EIC, o olhar, embora estivesse no outro, visto como modelo a ser seguido, no fim das contas, o resultado recaía sobre o eu. Dessa forma, a essência da comparação reside em reconhecer o outro para, nesse mesmo movimento reconhecer-se a si mesmo, a partir do estabelecimento de semelhanças e diferenças (cf. FRANCO, 2000).

Assim sendo, como pensar nessa relação com o outro a partir da articulação da Educação Internacional e Comparada com a Análise de Discurso francesa? E não somente a partir dessa articulação mas, sobretudo, a partir do objeto da comparação que, no caso desta pesquisa, são textos jornalísticos veiculados na mídia on-line. Nesse horizonte, há duas formas de percepção do outro num estudo comparado como este: a partir dos conceitos de sujeito e de função autor, com foco específico na produção textual. 
Como já mostrado, o sujeito, para a Análise de Discurso, é relativamente autônomo, isto é, a sua margem de atuação é limitada pelas condições sócio-históricas da sua constituição enquanto sujeito. Nesse sentido, os diversos lugares que o sujeito ocupa no discurso nem sempre são precisos, lineares ou podem ser determinados com exatidão. Quando se remete a um professor, por exemplo, na verdade, remetemo-nos à posição de sujeito que fala da posição de professor, lugar que não brotou do nada, mas tem sua historicidade. Esse mesmo professor, ao participar de um curso de pós-graduação como aluno, falará de outra posição (a de aluno), também carregada de seu processo histórico, político, ideológico. O que é importante aqui é que esse processo não se dá de modo automático, preciso ou sem falhas. Assim sendo, o professor que também é aluno em outro momento é, de alguma forma, afetado pelas outras posições que o constituem. Por isso, nem sempre falará como professor (estando no lugar de professor) nem tampouco falará somente como aluno, bem como em relação à posição de mãe, de pai, de patrão, de empregado.

Vê-se, dessa maneira, que a coerência não é parte essencial do funcionamento do sujeito, uma vez que as posições que ocupa são, em muitos casos, contraditórias entre si e, internamente também, podem não ser coincidentes, pois um sujeito que ocupa o lugar de professor pode não falar como professor, uma mulher pode usar um discurso machista, um membro de um partido de esquerda pode falar como se fosse de direita. Em todos esses casos, é importante destacar que o sujeito não tem acesso à sua inscrição nas diferentes Formações Discursivas e, portanto, são rituais sujeitos a falhas, o que não é um problema, mas é parte do funcionamento discursivo e, também, parte do funcionamento da ideologia (cf. ORLANDI, 1999).

Por outro lado, a função-autor é de outra natureza. Foucault (1999, p. 26) afirma, em relação ao autor, que não deve ser entendido "[...] como o indivíduo falante que pronunciou ou escreveu um texto, mas o autor como princípio de agrupamento do discurso, como unidade e origem de suas significações, como foco de sua coerência”. Num primeiro momento, tem-se a impressão de que a afirmação de Foucault contradiz frontalmente o que dissemos até aqui a respeito do sujeito. Entretanto, o autor é visto na Análise de Discurso como uma função que o sujeito exerce e, a partir do que Foucault (1999) apresenta, o autor é alçado à condição de assumir o lugar do eu no discurso e, dessa forma, trata-se da

[...] perspectiva que esse eu assume enquanto produtor de linguagem, produtor de texto. Ele é, das dimensões do sujeito, a que está mais determinada pela exterioridade - contexto sócio-histórico - e mais afetada 
pelas exigências de coerência, não contradição, responsabilidade etc. (ORLANDI, 1999, p. 75)

Dessa forma, tem-se que o sujeito é opaco e o discurso não é transparente, mas, ao contrário, exige-se do texto coerência, exatidão, clareza, adequação às regras textuais, relevância (cf. ORLANDI, 1999, p. 75-76). Observa-se, de forma mais explícita, tais características na escrita científica, em que tudo isso já citado é exigido do cientista, visto não mais como um sujeito no discurso, mas como autor, isto é, como aquele que organiza e dá um norte a um texto, sobretudo porque deve obedecer a uma rígida forma de escrita, com regras muito bem definidas. No texto jornalístico, objeto deste estudo, também tais características são exigidas sob pena de a informação ficar comprometida. Trata-se de uma função altamente afetada pela história, pois é muito diferente ser autor de texto científico da Idade Média e atualmente, bem como ser jornalista antes e depois da internet.

Muito embora o autor seja aquele que organiza o texto, conferindo-lhe coerência, começo, meio e fim, dentre outros aspectos, o processo de interpretação é sempre sujeito ao equívoco e, portanto, é sempre passível de derivar para sentidos não pensados, não estruturados no texto, não intencionados pelo autor. Dessa forma é que se torna possível analisar discursivamente um texto, pois não há como garantir plenamente que os sentidos pensados pelo autor sejam, de fato, exprimidos no texto ou, caso consiga exprimi-los, jamais conseguirá limitar o movimento de outros sentidos, uma vez que a constituição do corpus é de responsabilidade do analista e, portanto, está sempre sujeito à sua história, ao seu olhar.

Assim, um estudo comparado cujo objeto da comparação sejam textos, é preciso ter no horizonte essas duas formas de relacionamento com o outro. Há os sujeitos falantes que produzem sentidos, mas não necessariamente estão sujeitos a regras textuais ou de qualquer outra natureza e, também, os sujeitos exercem a função de autor, dos quais se exige coerência, coesão, consistência, limites, adequação às mais variadas regras, dentre outras características. Estabelece-se uma relação com o outro diferente em relação a estudos que comparam lugares, por exemplo. Em muitos desses casos, são realizadas entrevistas, grupos de discussão, dentre outras estratégias de pesquisa. Em geral, gravam-se as falas e, depois, são transcritas e, por fim, analisadas. No caso da nossa pesquisa, referimo-nos a textos construídos por meio da escrita e, além disso, são classificados dentro de um gênero bem definido, como o jornalístico (cf. MAINGUENEAU, 2010; 2015). Ao ler o texto, não temos os sujeitos diante de nós, como numa entrevista ou grupo de discussão, mas temos acesso ao outro pelo discurso, pela análise, 
pelas pistas deixadas na discursividade que o analista deve ser capaz de atingir ao enfrentar um texto.

Nessas duas possibilidades aparecimento do outro nos estudos comparados em que os elementos da comparação são textos escritos, no caso específico de textos de cunho científico, literário, jornalístico, a presença do autor, como mostrado, é necessária para a constituição do texto enquanto tal. Entretanto, a função-autor não estará, segundo Foucault (1999) presente em todos os textos escritos nem tampouco os sujeitos (que não exercem a função de autor) estarão explicitamente colocados no texto, mas podem estar silenciados. No primeiro caso, há textos em que a função-autor não é o elemento garantidor da significação, como, por exemplo, decretos e leis, cuja eficácia está no signatário e não no autor (cf. FOUCAULT, 1999, p. 26-27; ORLANDI, 1999, p. 75). Em relação ao silenciamento do outro, o papel do analista é fundamental para ler, no que está dito, como se dá esse processo de silenciar o outro no discurso. É o que podemos chamar de política do silêncio, pois, nesses casos, há regiões de sentidos que são proibidas a alguns sujeitos e é no discursos que se dá esse processo. Assim, por exemplo, dizer "selvagem" para o índio é impedir que se diga "cidadão" a respeito dele. Do mesmo modo, não se pode falar em ditadura em uma ditadura (cf. ORLANDI, 1990).

Novamente, é preciso destacar que o sujeito só é relativamente autônomo e o processo de produção de sentidos é, sempre, passível de falha e, portanto, pode ser diferente. Nesse sentido, ao mesmo tempo em que as políticas de silenciamento apagam sujeitos ( $o$ outro) nos discursos, é também esse mesmo mecanismo capaz de promover a resistência e as transformações. Assim,

[...] se de um lado o silêncio serve para pôr em funcionamento o apagamento de sentidos, ele serve também para produzir a resistência. Em uma fala (a do colonizador) já vem o que o outro não pode falar e assim conseguimos, através da explicitação desses processos de significação, trazer para o jogo da linguagem o "silenciado". Para isso é preciso sempre se observar: o que o colonizador não está dizendo quando está dizendo "x"? (ORLANDI, 1990, p. 52)

Para compreender esta passagem, é preciso remeter-nos a um dos pontos centrais nessa articulação da Educação Internacional e Comparada com a Análise de Discurso: promover leituras de mundo menos ingênuas. A interpretação deve permitir que os sujeitos percebam como funcionam os discursos e, assim, promover transformações. O papel do pesquisador é central nesse processo pois é com a ajuda de suas análises, que se pode perceber 
que estão dizendo "x" para não deixar "y" vir à tona. Desse modo, a partir da explicitação dos mecanismos de funcionamento dos discursos, os sujeitos serão capazes de perceber como se dão os processos de produção de sentidos e, nesse movimento, produzir resistências e transformações no discurso, na vida social ou na esfera educacional. 


\section{3 - Organização da pesquisa}

Não é possível construir um corpus sem realizar recortes. Nesse sentido, pode-se dizer que a sua própria definição já faz parte do processo analítico, pois escolher este ou aquele texto traz implicações para o rumo da interpretação. Na perspectiva adotada neste estudo, o texto não é mera ilustração de algum conteúdo, mas é parte do processo de significação, isto é, o modo como está organizado, o meio em que foi publicado, a data da publicação são elementos que têm forte influência na interpretação empreendida pelo analista.

Por isso,

Inicia-se o trabalho de análise pela configuração do corpus, delineando-se seus limites, fazendo recortes, na medida [...] em que se vai incidindo um primeiro trabalho de análise, retomando-se conceitos e noções, pois a análise de discurso tem um procedimento que demanda um ir-e-vir constante entre teoria, consulta ao corpus e análise. Esse procedimento se dá ao longo de todo o trabalho. (ORLANDI, 1999, p. 66-67)

No movimento de seleção dos textos já se tem, portanto, uma indicação analítica prévia da discursividade de um texto. Então, os critérios de busca das reportagens trazem esse recorte de pesquisa e, de alguma forma, delineia a seleção prévia dos textos.

O procedimento inicial se deu a partir da própria definição do tema. Ao decidir falar acerca dos discursos sobre sucesso e fracasso escolar em veículos da mídia on-line, um primeiro recorte estava estabelecido, dando um direcionamento para as etapas seguintes. A partir desse momento, era preciso procurar na internet os textos referentes ao tema. Entretanto, era preciso, primeiro definir o período tempo em relação à data de publicação dos textos. Ficou, assim, estabelecido que pesquisaríamos textos publicados entre 2000 e 2015, tanto em mídia especializada em educação, quanto em páginas não especializadas, mas que apresentassem uma seção relacionada à Educação. A escolha do referido período se deu por ser esse o período em que a banda larga se estabelece no Brasil de forma mais consistente ${ }^{7}$ e, a partir de então, veículos especializados na mídia on-line despontavam no país.

Em seguida, empreendeu-se à busca na rede propriamente dita, utilizando-se do Google como ferramenta de busca. Foram utilizadas palavras-chave como sucesso escolar, reprovação, distorção idade-série, fracasso escolar, casos de sucesso, sucesso na educação brasileira. Após algumas buscas e seleções dentro das opções apresentadas pelo buscador,

7 Fonte: http://www.tecmundo.com.br/banda-larga/2543-a-historia-da-conexao.htm, acessado em 27/06/2016. 
chegamos a trinta reportagens, que foram, inicialmente, ordenadas a partir da data de publicação, da mais antiga para a mais recente.

A partir daí, passamos a uma análise inicial dos artigos de modo a definir categorias como tema central, temas secundários, autor da matéria e veículo de imprensa. Nesta etapa, já foi possível perceber que alguns artigos não contemplavam a objetivo da pesquisa sendo, dessa maneira, excluído das próximas fases da pesquisa.

O momento seguinte foi de extrema importância pois foi realizada uma análise mais aprofundada, porém sem caráter conclusivo, de modo que foi possível agrupar as pesquisas em função de sua temática, permitindo, assim, que definíssemos as categorias que comporiam os capítulo dois e três destes estudo. Foram destacados nove textos para o capítulo 2 e quatro para o capítulo 3.Por fim, foram escolhidos oito textos (quatro para o capítulo dois e outros quatro para o três), organizados em pares de acordo com a temática central abordada

A última parte estará voltada para as considerações finais, cujo objetivo será retomar as comparações realizadas nos capítulos 2 e 3 com o intuito de promover indicações de como as questões educacionais trabalhadas na pesquisa podem ser encaminhadas ou, ao menos de que maneira pode ser objeto de uma reflexão mais profunda. 


\section{Capítulo 2}

\section{Reprovação e progressão continuada: estratégias de construção e circulação dos discursos}

\subsection{Reprovação em pauta}

No primeiro grupo de textos a serem analisados, será abordada a temática da reprovação, com o objetivo de produzir análises discursivas o mais vertical possível de cada um dos textos. Desse modo, teremos elementos suficientes para a análise comparativa a ser realizada na próxima seção.

É preciso destacar, ainda, que, embora o tema central seja a reprovação, a análise discursiva não ficará restrita nessa questão. Ao trabalhar as regiões discursivas por onde o texto transita, busca-se uma interpretação do que não está evidente numa primeira leitura. Esse tipo de análise permite compor um quadro discursivo mais abrangente, essencial para um estudo comparativo.

\subsection{1 - Análise Discursiva do texto 1}

A matéria A arqueologia da reprovação, do economista Cláudio de Moura Castro, publicada em 06/12/2000, na VEJA Educação, tem como tema central a reprovação e procura discutir o tema a partir dos resultados do Saeb 1999.

\section{A arqueologia da reprovação}

"A avaliação da educação básica de 1999 permanece uma esfinge, desafiando nossa capacidade de decifrá-la. Mas, espremendo os dados, alguns fragmentos de explicação começam a emergir"

Acabam de aparecer os resultados do Sistema Nacional de Avaliação da Educação Básica (Saeb) trazendo notícias do ensino brasileiro. Predominam resultados positivos, pois há 1 queda na distorção idade-série e um crescimento extraordinário das matrículas e conclusões, em todos os níveis. Um terço de nossa população freqüenta escolas. Em 1930, quando foi criado o MEC, só $5 \%$ dos brasileiros iam à escola.

Contudo, os testes de português e matemática mostram uma tendência geral para a queda. Não é dramática, mas preocupa. Foram tentadas muitas explicações. As perícias nos testes ainda não são definitivas (teria ficado mais difícil?). Outro suspeito seria o rápido processo de municipalização, decorrente do Fundef (o fundo que redistribui verbas da 
educação segundo o número de alunos matriculados numa cidade). Alvíssaras, o desempenho das escolas municipais não piorou em relação ao das estaduais.

A esfinge do Saeb ainda não foi decifrada (se há nisso algum consolo, a maior pesquisa americana sobre rendimento de alunos, o Coleman Report, passou dez anos gerando 3 controvérsias em sua interpretação). Mas, espremendo os dados, alguns fragmentos de explicação começam a emergir. Verificou-se que há quedas tanto para os alunos mais pobres quanto para os ricos e, para confundir ainda mais, caíram as particulares também (que pouco têm a ver com a ação do Estado).

Há mais tendência de queda nos Estados onde a matrícula cresceu mais e aumentou a distorção idade-série, como no Nordeste. Como esses alunos adicionais (incorporados ou

4 retornados) são mais fracos ou mais pobres, ao tê-los em maior número, cai a média. Contudo, há Estados crescendo sem queda de rendimento e há quedas dentre os filhos dos mais educados. Deve haver outras causas.

Vivíamos sob a "cultura da repetência", na qual a marca do ensino sério era reprovar 5 muitos alunos. Nos últimos anos estamos reconhecendo o equívoco de tal prática e também criando ciclos de dois ou três anos, dentro dos quais não há reprovação.

Note-se, nos países avançados - cuja educação é escandalosamente melhor que a

6 nossa - não há alunos reprovados e repetindo o ano. Repetência é relíquia arqueológica de país atrasado.

Já medimos: quanto mais repetência, mais baixo o rendimento. Frustra, derrota o aluno, mas não aumenta seu rendimento, mesmo comparado com o aluno que foi aprovado sem saber muito. Ou seja, mesmo o aluno que aprendeu pouco lucrará mais se for adiante, junto com seus colegas.

Mas, ao abandonar a cultura da repetência, há que aprender a viver sem ela. Para a classe média, operava um mecanismo altamente eficiente: "a cultura do medo da repetência", 8 pois é esse medo que faz o aluno estudar. $\mathrm{O}$ filho de família educada estuda e passa, com medo da "bomba" e dos castigos. Na prática, quem repete é o filho de famílias pouco educadas, para quem a ameaça da repetência não é um incentivo eficaz.

Ao eliminar a reprovação, a escola tem de substituí-la por outros mecanismos de prêmios e punições, pois o gosto pelos estudos é munição insuficiente para trocar a televisão 9 pelos livros. Ainda engatinhamos nesse aprendizado. Sem a reprovação, cai a pressão para estudar, até que apareçam outros mecanismos adequados para substituí-la. Caímos em uma entressafra de prêmios e puxões de orelha.

Essa poderia ser uma das causas da queda no rendimento e das reclamações dos professores - que perderam suas armas para fazer o aluno estudar. É verdade. Contudo, eram péssimas armas, que estimulavam as famílias educadas, mas puniam as pobres e mais numerosas. São Paulo já definiu alternativas razoáveis (recuperação, aulas de reforço), porém

10 aprender a usá-las parece levar algum tempo. Como um drogado que sofre inicialmente ao ter cortado seu vício, eliminar a reprovação traz problemas de transição. E, obviamente, eliminar reprovação não se confunde com eliminar a avaliação. Pelo contrário, esta tem de ser melhor, mais freqüente e acoplada a outros prêmios e punições.

Mas estamos no campo das especulações. A avaliação da educação básica de 1999

11 permanece uma esfinge, desafiando nossa capacidade de decifrá-la. Porém o assunto é demasiado importante para permitir desânimo.

Texto 1: A arqueologia da reprovação - publicado em 06/12/2000 por Cláudio de Moura Castro na VEJA Educação. Disponivel em http://veja.abril.com.br/idade/educacao/061200/ponto_de_vista.html, acessado em 30/12/2015. 
O objeto discursivo não está evidente, nem é dado pelo texto, no sentido de que bastaria ao analista encontrá-lo nas "entrelinhas". Ao contrário, é um trabalho que depende da posição do analista, sua história e, também, sua história com a língua. É um movimento teórico que objetiva sair da superfície linguística para a esfera discursiva, suplantando a ilusão de obviedade e de realidade, como se o texto fosse, de fato o retrato do mundo enquanto tal (cf. ORLANDI, 1999, p. 66).

Nesse trabalho do analista, a conversão do texto (corpus bruto) em objeto teórico, é preciso sair da pura empiria para podermos entender como um texto produz sentidos e não somente, como na análise de conteúdo, ficar na superfície do empírico, o que permite apenas questionar o que um texto quer dizer. Para a Análise de Discurso, é a partir do texto, enquanto unidade de análise, que esse processo se inicia. Desse modo, quem escreveu o texto não deve ser analisado enquanto indivíduo empírico, mas como sujeito que ocupa um lugar no discurso a partir da filiação a uma Formação Discursiva, que, como vimos, é uma espécie de regionalização do discurso em que não se pode dizer tudo e, em função do lugar que o sujeito ocupa, as palavras significam de um modo e não de outro (cf. ORLANDI, 1999).

A partir dessas considerações, é possível compreender como começar a sair da textualidade para discursividade. O ponto de partida, por se tratar de um estudo situado no campo da Educação Internacional e Comparada, é, sem dúvida, o olhar para o outro que deve ser visto tanto como o sujeito do discurso quanto a função-autor ${ }^{8}$. No caso de um texto de cunho jornalístico, a autoria é fundamental pois disse depende, em grande medida, a articulação do texto enquanto unidade de significação. De um lado, a função-autor, neste caso, atua como elemento estabilizador - precário - do processo de significação, dando um direcionamento de sentidos, de coerência, de organização, de respeito às regras editoriais, dentre outros aspectos. Em função disso, podemos chamar "Arqueologia da reprovação" de um texto jornalístico porque há algo que organiza o texto enquanto tal e nos permite estabilizar, ainda que de forma tênue, a unidade do elemento textual. Por outro lado, o outro da EIC também é visto no discurso como o sujeito que ocupa um lugar inscrito em uma Formação Discursiva. Aqui não se espera coerência, organização, completude. É nessa tensão entre estabilidade e precariedade que o processo de significação ocorre e é papel do analista explicitar seu modo de funcionamento.

Nesse sentido, o texto é obviamente organizado do ponto de vista estrutural, coerente do ponto de vista da sua construção e está de acordo com o que, de modo geral, 8 Ver seção 1.2 do Capítulo 1. 
definimos um texto. Esse é o efeito da função-autor, pois o texto é apresentado de forma linear e, aparentemente, transmite um sentido objetivo, até porque o texto é construído em torno da interpretação do Saeb (Sistema Nacional de Avaliação da Educação Básica ${ }^{9}$ ) do ano de 1999 e, portanto, possui um foco nos dados. Justamente nesse ponto, observa-se que os sentidos não são tão objetivos quanto preconizado pelo autor, na medida que, pela polissemia, sempre derivam para outros sentidos e, mesmo um texto pretensamente objetivo, como um texto jornalístico, sempre apresenta possibilidades diferentes de interpretação. Os sentidos, contudo, não estão nas palavras, mas aquém e além delas (cf. ORLANDI, 1999)

Observa-se, em relação a esse aspecto, alguns pontos importantes. Primeiramente, muito embora as palavras não carreguem em si mesmas seus sentidos, trazem no seu uso a constante referência à história e aos processos sociais que constituem o dizer. Portanto, é preciso sempre remeter o dizer às suas condições de produção, isto é, à situação de enunciação e, também, às condições sócio-históricas do dizer. Tal afirmação é particularmente importante pois é preciso remeter um texto a outro, um discurso a outro para que as palavras façam sentido. Além disso, destaca-se que nem sempre o sujeito pensa deliberadamente em todos os sentidos para os quais as palavras apontam, mas estas são atravessadas pela história e, portanto, independentemente da vontade do sujeito dialogam com outras pela história, pela memória, nem sempre acessível ao sujeito enunciador (ORLANDI, 1999, 43).

No parágrafo 3 percebe-se essa relação. Não importa se o autor queria usar um termo neste ou naquele sentido. O relevante para o analista é compreender como as palavras dialogam com as outras no discurso. No relacionamento com outros termos, o texto remete a uma ou mais Formações Discursivas, e, assim, é possível compreender de onde as palavras “tiram” seus sentidos. Dessa forma, são colocados lado a lado nos trechos 3-1 e 3-2 os termos "Saeb" e "Coleman Report", colocado-os em referência mútua, de modo que os sentidos se entrecruzam de forma decisiva para a interpretação.

Ao mesmo tempo em que nutria expectativas de obter respostas mais concretas acerca da educação brasileira nos números do Saeb, pela referência à esfinge, da qual se esperava $a$ resposta correta (cf. SÓFOCLES, 2005), o autor menciona que o Coleman Report ${ }^{10}$ passou uma década procurando respostas e não as obteve de forma satisfatória. Trata-se de um relatório produzido pelo governo dos Estados Unidos sob o título Equality of educational

9 Para mais informações sobre o Saeb: cf. HORTA (2007); HORTA (2010); BONAMINO \& FRANCO (1999); GATTI (2009).

10 Para mais informações: cf. Gamoran, A., \& Long, D. A. (2006). 
opportunity (1966). A interpretação só é possível se relacionarmos o dito com o não-dito. Para a Análise de Discurso, o não dito é tão importante quanto o que é dito. Entretanto, nem toda palavra não dita que deve ser levada em consideração e, além disso, não se trata de mera ilação ou dedução. É, na verdade, uma questão de método, pois, para a $\mathrm{AD}$, o não-dito é acessado a partir do próprio texto, isto é, não em algo por trás do texto, mas a materialidade linguística dá indícios acerca do não-dito e este é o guia para o(a) analista. Outra questão a se observar é que nem tudo o que é dito é relevante para a análise, mas somente o que se relaciona diretamente àquela situação significativa (cf. ORLANDI, 1999, p. 83)

Ao colocar lado a lado Saeb e Coleman Report, estabelece-se uma correlação entre os termos de modo que são tratados como semelhantes enquanto importância informativa para seus respectivos países e justifica-se a incapacidade na interpretação do Saeb pela dificuldade que os Estados Unidos tiveram na interpretação do seu relatório. Se pensarmos da perspectiva da função-autor, é preciso observar que a relação estabelecida entre os países nada mais é que um recurso retórico, algo que apenas serve de ilustração, dá coerência ao texto e aos argumentos. Vê-se, no entanto, do ponto de vista da ação do sujeito no processo de construção de sentidos, que há sentidos não ditos, mas que são importantes para o discurso. Dessa forma, a dificuldade estadunidense na interpretação do seu relatório pode configurar-se um consolo para o Brasil na medida em que eles são um parâmetro de qualidade para os brasileiros e, se eles tiveram controvérsias na interpretação dos seus dados, também estaremos autorizados a não conseguir interpretar o Saeb.

Em nenhum momento é afirmado explicitamente que os Estados Unidos estão à frente do Brasil, mas o uso como exemplo do Coleman Report já estabelece essa relação hierarquicamente desigual entre os países. Nesse sentido, qualquer outro país que apresente alguma dificuldade na interpretação dos resultados de algum exame ou relatório referente à educação poderia ter sido usado como exemplo. Entretanto, ao usar esse país específico, dizse, naquilo que não está dito, que aquele país pode ser usado como referência de qualidade e, portanto, como eles tiveram dificuldades, outros também apresentação as mesmas queixas.

Ainda seguindo, de algum modo, essa relação hierarquizada entre os elementos relacionados, o autor trabalha com a relação entre pobre/pobreza, classe média e reprovação/aprovação nos parágrafos 3-4, 3-5, 4, 8, e 10. Em todos esses trechos há algum tipo de relação estabelecida entre pobreza e reprovação e da classe média com sucesso escolar. Analisaremos os trechos separadamente e, depois faremos as correlações entre eles. 
No trecho 3-4, uma leitura inicial indica que se trata apenas de constatação dos dados. Seria, portanto, uma afirmação meramente descritiva sem qualquer juízo de valor por parte do autor. O conjunto de informações aponta para a conclusão, quase óbvia, que o ensino de um modo geral está muito ruim pois houve queda entre os mais pobres, entre os ricos e entre os oriundos de escolas particulares.

Observa-se, no entanto, que há pistas no próprio texto que promovem uma espécie de quebra da linearidade dos sentidos, fazendo com que derivem para lugares que não foram necessariamente pensados pelo sujeito. No caso dos excertos 3-4 e 3-5, a pista fundamental a seguir é o trecho "para confundir ainda mais". O período é construído de forma tal que, de fato, a impressão que sem é a de simples transmissão a informação de que houve queda entre mais pobres e entre ricos. Além disso, a "confusão" parece estar somente no fato de constatou-se queda também entre as particulares. É interessante notar que o "confunde" não é somente a queda nas instituições privadas, mas também o fato de que entre os ricos também viu-se queda no Saeb, assim como entre os pobres, não dito, mas colocado como esperado, sobretudo na expressão "ainda mais", que é dita para não dizer explicitamente que já havia certa surpresa ao ver queda entre ricos e pobres.

Outro aspecto importante destacado nesse parágrafo (trecho 3-5) é o que trata dos resultados das escolas particulares. A constatação de queda, numa primeira leitura, aponta para um aspecto, de certa forma, positivo, de dizer que nem tudo é perfeito no ensino privado brasileiro. Entretanto, a análise discursiva mostra que há, neste trecho, mais do que simples afirmação. É fundamental observar que, para interpretar a queda das escolas particulares no Saeb, o autor faz um comentário que desloca o sentido para um outro lugar, o do discurso sobre o que é uma gestão eficiente. Retoma-se, assim, a expressão "ainda mais" que, além de remeter à parte inicial no parágrafo, aponta, também para o rendimento das particulares. Estas, segundo o texto, têm pouco "a ver com a ação do Estado", mostrando que a queda não era o resultado esperado pois a ação do Estado seria danosa e ineficiente e, portanto, uma entidade que não tem a participação direta do Estado não deveria ter queda no rendimento. Portanto, por meio da análise, é possível perceber que o autor não crê muito na possibilidade de ação positiva do Estado e que a escola particular tem um modelo mais adequado. É o Estado, para o autor, o grande responsável pelo fracasso. Daí decorre que tudo venha a “confundir ainda mais" a visão do autor, que não esperava queda nas particulares, consideradas mais eficientes. Obviamente, nada disso está escrito explicitamente no texto nem 
tampouco está nas entrelinhas. Está dito no não-dito do texto, isto é, a partir do que disse o sujeito, é possível compreender como o que é dito remete a um não dito, que significa no dizer.

Essa relação entre o que se diz e o não-dito é parte do funcionamento da Formação Discursiva a que está inscrito o sujeito, região do discurso em que não se pode dizer tudo. Assim, não é conveniente a um economista que escreve em revista de grande circulação (sobretudo por ser uma matéria publicada on-line, em que as possibilidades de propagação aumentam exponencialmente) afirmar categoricamente que é muito confuso compreender como pobres e ricos tiveram queda no Saeb, uma vez que o esperado era que os ricos melhorassem seu desempenho ou, ao menos não caíssem. Não interessa para a Análise de Discurso se o sujeito pensou em tudo isso para articular o texto. O que importa é que o modo como a sentença foi escrita significa de um modo específico em função de sua sintaxe ou das palavras escolhidas. É preciso ficar claro, portanto, que não afirmamos com tudo isso que o autor acha estranho que pobres e ricos tenham queda no exame. Isso é impossível definir a partir somente do texto. $\mathrm{O}$ que o analista tem de investigar não é $o$ que o sujeito pensa, mas como os sentidos são articulados num texto, pois os sentidos não são controláveis nem pelo sujeito (controle exercido precariamente pelo autor) nem pelo analista, que o aporte teórico-metodológico para produzir um dispositivo de interpretação que lhe permita relacionar o dito como o não-dito com as Formações Discursivas, assim, acessar os mecanismos de construção dos sentidos e o funcionamento da ideologia.

$\mathrm{Na}$ sequência, o parágrafo 4 faz um percurso parecido, mas com outras especificidades. Aqui, o texto é construído em torno da lógica argumentativa do tipo $\mathrm{A}+\mathrm{B}=\mathrm{C}$. A primeira relação de fatores que geram um determinado resultado é no trecho que começa em 4-1 e termina em 4-2. Aqui, os números confirmariam que nos lugares onde houve aumento nas matrículas e aumento na distorção idade-série, observou-se uma maior tendência de queda. A região Nordeste é utilizada como exemplo dessa situação. Na segunda parte do parágrafo (4-2 e 4-3), é estabelecida uma outra relação lógica que consiste na constatação de que alunos adicionais advindos do aumento das matrículas, por serem "mais fracos ou mais pobres" e, além disso, em grande quantidade, promovem a queda da média do estado ou da região. Levanta, dessa forma, o debate acerca do par qualidade versus quantidade, isto é, "a ideia de que temos de passar da fase de 'mais' educação (entendida como o aumento do percentual de crianças na escola) para uma educação de melhor qualidade [...]" (VELOSO, 
2009, p. XV). Os referidos trechos colocam-se, assim, como parte desse debate maior, tendo os números do Saeb como embasamento para o debate.

A segunda parte do parágrafo (4-2 e 4-3) seria a explicação lógica desse movimento de entrada dos alunos na escola. Os alunos adicionais, segundo o texto, são "incorporados" - matrículas novas - ou "retornados" (alunos que deixaram a escola em algum momento e agora retornam fora do fluxo regular) e são "mais fracos" ou "mais pobres". Pela sintaxe, que não é alheia à produção de sentidos, percebe-se quem esses alunos a partir da estrutura sujeito/verbo de ligação/predicativo do sujeito ${ }^{11}$. Temos os alunos adicionais (sujeito), são (verbo de ligação) e mais fracos ou mais pobres (predicativo do sujeito). Além disso, advérbio mais é necessariamente relacional e, portanto, indica intensidade em relação a outro elemento. Assim, são mais fracos ou mais pobres em relação aos alunos que já estão na escola. Compreende-se perfeitamente que um aluno com distorção idade-série pode apresentar mais dificuldades de aprendizado ou de socialização (por estudar com alunos de faixas etárias diferentes) do que os alunos com fluxo regular. Entretanto, é digno de menção a questão da pobreza como elemento necessariamente dificultador do rendimento escolar. Também não se pode negar que alunos com dificuldades no âmbito social e financeiro podem, igualmente, ter dificuldades nos estudos, entretanto, o autor coloca num mesmo nível semântico os termos mais fracos e mais pobres. Significa que a simples presença em grande número de alunos mais fracos e mais pobres representa a queda no rendimento no Saeb. Cria-se, dessa maneira, uma estrutura sintática e semântica muito consistente do ponto de vista formal, fazendo com que a leitura do texto seja direcionada para o entendimento lógico de que uma situação leva a outra, ou seja, que alunos mais fracos ou mais pobres entrando no sistema é um grande problema para a educação brasileira. Reforça, enfim, que a educação deve servir a uma elite se quiser manter seus níveis de rendimentos mais altos.

Na última parte do parágrafo (trechos 4-3, 4-3 e 4-5) é interessante observar que o autor constrói uma relação de oposição em relação às ideias apresentadas anteriormente, mas analisando mais profundamente, embora afirme A, percebemos que o discurso aponta para B. Toda a construção lógica da primeira parte do parágrafo não é utilizada neste trecho cuja estrutura é afirmativa e categórica: existem Estados que crescem em número de alunos e não apresentam queda de rendimento bem como há filhos dos mais educados que apresentam queda de rendimento. Novamente, o jogo entre o dito e o não-dito dão a tônica do discurso, pois há um paralelo entre este trecho e o analisado anteriormente. Pode-se colocar, de um 11 Nesse tipo de estrutura, o predicativo do sujeito caracteriza o sujeito da oração. 
lado, os Estados que tiveram aumento nas matrículas e com tendência de queda e, de outro, aqueles que crescem sem apresentar queda no rendimento. Um outro par pode ser formando com alunos mais fracos ou mais pobres - cuja média cai em função da quantidade de estudantes com essas características - e com os filhos dos mais educados que apresentam queda.

Assim, é preciso analisar o parágrafo 4 a partir da presença ou ausência de palavras nos pares enunciativos que destacamos anteriormente. Primeiramente, em 4-2, o Nordeste é um exemplo de região em que há estados em crescimento de matrículas e com queda de rendimento, enquanto que em 4-3 e 4-4 não se nomeiam os Estados que crescem sem queda de rendimento. Nesse jogo de presença/ausência, a argumentação procura deixar explícito o fato de que o Nordeste brasileiro é uma região que apresenta queda de rendimento no Saeb, enquanto que no trecho 4-4 há um apagamento total nos exemplos. Tal estratégia enunciativa se liga diretamente ao outro par mencionado pois esses alunos mais fracos e mais pobres estão no Nordeste. Em outras palavras, o discurso procura conduzir o sujeito leitor a trilhar um percurso no qual os Estados com mais matrículas são um problema por trazerem para o sistema alunos mais fracos e mais pobres e, além disso, há uma concentração maior desse tipo de situação em Estados da região Nordeste. Por outro lado, ao nominar a região cujos Estados apresentam queda e não fazer o mesmo nas que também apresentam aumento nas matrículas, mas não apresentam queda no rendimento, significa enfatizar, apenas, a região mais pobre, a que traria problemas para a educação do país ${ }^{12}$.

Por isso, na $\mathrm{AD}$ trabalha-se com os esquecimentos e, neste caso, o número dois, que é da ordem da enunciação. Segundo esse conceito, é preciso que o sujeito "esqueça" que o enunciado sempre pode ser outro (cf. ORLANDI, 1999, p. 35). Assim, para falar/escrever, o sujeito precisa crer que a forma escolhida para o texto é $a$ forma, pois, caso contrário, o sujeito se perderia numa infinidade de possibilidades e cairia no sem sentido. Cria-se, dessa maneira, uma relação natural entre a palavra e o mundo, cristalizando certos modos de falar, como se fosse mesmo como se apresenta na lógica da enunciação. Entretanto, sempre se pode formular uma sentença de outra forma, mobilizando, assim, outros sentidos. Em relação ao trecho analisado, a informação em destaque não é que há estados crescendo sem queda de rendimento. $\mathrm{O}$ que fica numa primeira leitura é que existe tendência de queda no rendimento

12 Segundo Orlandi, "Na perspectiva do nosso trabalho, importa menos saber o que ficou silenciado e mais a própria política da palavra: que ' $x$ ' se disse para não se dizer ' $y$ '? Como esse ' $y$ ' silenciado acaba por significar ao longo das diferentes falas e dos seus apagamentos?” (ORLANDI, 1990, p. 51). 
em Estados do Nordeste que apresentam aumento no número de matrículas e que esses alunos acrescidos ao sistema são mais fracos ou mais pobres e essa é a causa da queda verificada. Além disso, trata o Nordeste como um bloco homogêneo de Estados em que todos os jovens que adentram o sistema são pobres e fracos.

Com relação ao outro par destacado, o primeiro aspecto refere-se ao modo de referência, pois já se evidencia que os "filhos dos mais educados" não são nem pobres nem fracos ou, numa relação de paráfrase, são mais fortes/menos fracos ou menos pobres/mais ricos. Dessa forma, associa-se diretamente a condição social com a condição intelectual, criando uma relação natural entre a palavra e o mundo. Esse trabalho de criar evidências é o trabalho ideológico por excelência, na medida em que "cola" certos sentidos nas palavras, tornando-os lógicos, claros, transparentes.

Outro ponto importante do texto (parágrafo 8) traz, sob uma outra roupagem, a relação entre pobreza e classe média no que diz respeito ao processo posterior à superação, segundo o texto, da "cultura da repetência". Os pares relacionais são estabelecidos aqui da seguinte forma: classe média/medo de reprovar, famílias pouco educadas/sem medo de reprovar. Ao tratar da classe média (trechos 8-1, 8-2, 8-3 e 8-4), o autor estabelece relações estruturadas como naturais. Estabelece-se, a partir dessa lógica, a ideia de que os filhos de famílias educadas (conforme o texto, a classe média) eram aprovados pelo medo de reprovar. A simples pressão faz com que o aluno oriundo de família da classe média estude e passe, "com medo das bombas e dos castigos". Por outro lado, afirma que, no fim das contas, quem reprova mesmo é o filho das famílias menos educadas (os pobres). Complementa, ainda, que ameaçar um aluno de família pouco educada "não é um incentivo eficaz" (trecho 8-4 e 8-5). O texto é construído de forma tal que fica evidente e explícito que é uma tarefa inútil cobrar algo de alunos mais pobres, de famílias pouco educadas. Entretanto, não há nenhuma explicação no texto que justifique tal afirmação.

Novamente, vê o trabalho da ideologia, naturalizando uma relação que não há absolutamente nada de natural, pois dizer que o "filho da família educada estuda e passa" é, nada mais que um argumento elitista, que coloca o aluno de classe média numa condição naturalmente superior sob dois aspectos. Primeiro, que haveria, segundo essa visão, uma consciência maior por parte do aluno que, entende a pressão que lhe é exercida, respondendo, assim, com estudo e com aprovação. Além disso, teria uma condição intelectualmente superior em relação ao aluno de família pouco educada porque é capaz de passar porque, de 
alguma forma, tem capacidade de compreender minimamente os conteúdos e, portanto, tornar-se capaz de conseguir a aprovação.

Por outro lado, o jovem pobre, de família pouco educada, caminha, segundo o texto, em direção oposta. Se utilizarmos o mesmo raciocínio aplicado ao aluno da classe média, podemos entender o aluno mais pobre porque não teria consciência do seu papel como estudante e, assim, tanto faz ameaçar ou não, uma vez que não é possível ter medo daquilo que não é sequer contemplado pela consciência. Em outras palavras, o aluno de família pouco educada, não tem medo de reprovar porque simplesmente não teria a dimensão que uma repetência representa na sua vida e na família como um todo. Além desse aspecto, não teriam também capacidade intelectual de aprovar, nem sob ameaça, ou seja, ainda que se coloque o aluno diante da possibilidade de reprovar, não adianta ameaçar pois não tem condições de estudar e passar, porque não teria capacidade intelectual.

Nessa discussão, é interessante observar que a noção de reprovação, nesse texto, é determinante atravessada pelo efeito diferente que o ato de reprovar tem para públicos diferentes, a saber, classe média e famílias pobres ou, segundo o texto, família pouco educada. Nota-se, ainda, que se constrói o texto com uma aparência de denúncia, pois ao dizer que "na prática" os repentes são os mais pobres, alertaria a sociedade acerca desse grave problema. Entretanto, a análise discursiva explicita que, ao determinar que não adianta ameaçar o pobre, este passa a ser um caso quase perdido, pois nem a ameaça e o medo são eficazes. Diferentemente do filho de classe média, que tem na reprovação uma tragédia e, assim, ameaçar resolve. Trata-se de uma generalização perigosa afirmar que os filhos de classe média são aprovados porque têm medo de reprovar e dos castigos e que, ao contrário, os filhos de famílias pouco educadas não têm medo de reprovar e dos castigos. Há muitos jovens de classe média que não estão nem um pouco preocupados com reprovação ou com castigos bem como há muitos jovens pobres que ficariam muito preocupados com a possibilidade de reprovação e, portanto, poderiam reagir e conseguir aprovação. A questão da reprovação não deve ser entendida, dessa maneira, como uma questão não somente social, mas também pedagógica.

No debate sobre a reprovação, um tema fundamental é a questão da avaliação, que é contemplada no texto apenas em três linhas (10-6, 10-7 e 10-8). A avaliação associada a "prêmios e punições" afasta-se de uma visão puramente pedagógica do processo e aproxima o 
discurso à visão empresarial do processo, que visa premiar o funcionário com melhores resultados e punir aquele que não se enquadra no sistema.

Portanto, avaliar e, consequentemente, aprovar ou reprovar não deve passar por outros mecanismos que não seja a aprendizagem. Entretanto, falar em prêmios e punições faz do discurso pedagógico algo palpável, diferente de aprendizagem, elemento sempre difícil de ser quantificado. Por isso, tanta ênfase nos resultados do Saeb que, vale dizer, são puramente quantitativos e, dessa maneira, de fácil visualização em um ranking. Entretanto, pedagogicamente falando, não devemos nos ater somente ao número e simplesmente premiar quem se sai bem nas avaliações e punir quem vai mal não é o melhor caminho, mas sim trabalhar cada aluno em sua especificidade, compreendendo como diferentes formas de abordar e avaliar um determinado conteúdo podem surtir efeito em sala de aula, seja de classe média, seja entre alunos mais pobres. A questão não deve ser social, mas pedagógica. 


\subsection{2 - Análise Discursiva do texto 2}

O texto Ensino Reprovado, publicado por Gilberto Nascimento na Revista Isto É, em 2001, traz diversas situações relacionadas ao estágio atual da educação brasileira, sobretudo o que está ligado à questão da reprovação, do aprendizado e, também, abordar aspectos relativos ao papel de diversos agentes (poder público, professores) no processo de ensino/aprendizado.

\section{Ensino Reprovado}

Sem repetência, alunos de escolas públicas chegam até a sexta série sem saber ler, escrever nem fazer as quatro operaç̃̃es aritméticas

Esta reportagem começa com uma frase absolutamente incompreensível: No dina vit do de Abinu d doni come kicnado no ba Basinu terã mlazsa. Esta aparentemente insólita junção de letras é o resultado de uma realidade triste. Foi a tentativa de Welton, 11 anos, aluno da quarta série de uma escola municipal da zona leste de São Paulo, reproduzir um ditado singelo, sugerido por uma professora na sala de aula. Ele deveria ter escrito o seguinte: "No

1 dia 22 de abril, comemoramos os 500 anos do nosso Brasil, que é uma terra maravilhosa." Welton é apenas um exemplo de uma situação perversa reinante no ensino público. A escola hoje está formando, com diploma e carteirinha, subcidadãos despreparados para o futuro. Crianças, afinal, estão saindo da escola sem saber ler nem escrever. Tampouco fazer as quatro operações aritméticas. É o dinheiro do contribuinte indo para o ralo, num círculo vicioso: os governantes fingem investir em educação, a escola finge que ensina e o aluno finge que aprende.

Nos rabiscos de Welton há algo que lembre - ainda que de longe - uma palavra acabada. Para outros de seus colegas, nem isso é possível. Numa outra área da zona leste paulistana, o Jardim Santo Elias, a cerca de 20 quilômetros do Centro, a reportagem de ISTO É presenciou outra cena: o esforço de quatro irmãos para tentar repetir a mesma façanha de

2 Welton. Sem sucesso. Roberto, 15 anos, Marcelo, 14, Diego, 12, e Rodrigo, 11, contorceram-se de um lado para outro, tentaram "colar" e depois olharam para o vazio. Seguiram-se dez minutos de um silêncio. Uma vizinha que os acompanhava saiu do quarto com os olhos marejados.

Ao final, os garotos exibiram garranchos e sinais ininteligíveis. O mais velho, em vez do ditado, colocou no papel três das raríssimas palavras que conhece: amei, come e boi. Órfãos de pai e mãe, os quatro conseguem escrever apenas o nome e não lêem nada, nem fazem contas. Roberto está matriculado na quinta série, numa escola municipal. Rodrigo e Marcelo, alunos da quarta série, e Diego, da segunda, estudam em outra, estadual. Frequentam as aulas regularmente. Segundo Roberto, nunca fazem exercícios na sala de aula porque não entendem

3 o que a professora pede. Ao ser perguntado como os professores reagem diante do fato de ele não saber ler, o menino não soube responder. Lágrimas começaram a descer de seu rosto. "O que mais eu queria na vida era ler", lamenta. Ao ver o que nove estudantes do ensino fundamental escreveram, o ministro da Educação, Paulo Renato Souza, teve uma reação de espanto. "É o fracasso da escola. Ela tem de fazer o aluno aprender. Temos de cobrar e exigir dedicação dos professores. Precisamos trocar essa cultura da reprovação, mas com avaliação.”

O ministro reconhece a deficiência do ensino. Mas não se cansa de dizer que nunca

4 nenhum governo fez tanto pela educação no Brasil. Só que na periferia de São Paulo e nos 
grotões do País, essa realidade parece estar a anos-luz. O Brasil sempre foi um dos campeões mundiais de repetência. Até recentemente, a escolaridade média era de três anos e meio, apesar de a maioria das crianças permanecer por dez anos na escola. Isso custa aos cofres públicos R\$ 3,5 bilhões ao ano.

Ciclos - Para atenuar esse quadro, a Lei de Diretrizes e Bases (LDB) da Educação Nacional, de 1996, instituiu a chamada progressão continuada, hoje implantada em grande parte do País. Nas redes municipal e estadual de ensino de São Paulo, por exemplo, o aluno é avaliado ao final de um primeiro ciclo (da primeira à quarta série) e num segundo (da quinta à

5 oitava). A avaliação deve ser feita sem prejuízos ao aprendizado e levando-se em conta a frequência escolar. Quem repetir num dos dois ciclos passa pelo processo de "aceleração" (ou recuperação). Educadores sérios elogiam o sistema de progressão continuada. Estatísticas mostram que o aluno não repetente passa a ter um desempenho melhor na escola. Segundo pesquisas, esse sistema de avaliação impede o afastamento definitivo da escola, evita a diminuição da auto-estima e traz novos estímulos pelo fato de o aluno estudar na mesma série que colegas de idade idêntica. A proposta começa a ir por água abaixo, porém, quando a "aceleração" não corresponde às expectativas.

Professores e diretores garantem que o drama de Welton ou o de Roberto e seus irmãos repetem-se em qualquer escola localizada em regiões pobres. Dizem que hoje não podem "reprovar ninguém". Segundo eles, quando se descobrem casos como esses as secretarias de Educação costumam abrir sindicância e somente os professores acabam penalizados, enquanto o governo não cumpre a sua parte. Alunos chegam até a sexta série sem saber ler, de acordo com os professores, porque grande parte deles necessita também de acompanhamento psicológico, tratamento médico ou atenção e dedicação exclusiva, o que a escola não estaria preparada para oferecer. "Hoje o professor recebe por três horas a mais para dar reforço ao aluno que não consegue progredir no horário normal de aulas", contesta Maria Moreira Fernandes, responsável pela Coordenadoria de Ensino da Região Metropolitana de São Paulo, órgão da Secretaria Estadual de Educação. "Toda a rede também recebe por mais duas horas adicionais para discutir propostas pedagógicas. A competência coletiva deve ser colocada a serviço da aprendizagem do aluno."

Polêmica - A psicóloga e especialista em educação Cenise Monte Vicente, excoordenadora do programa de combate à repetência escolar Acelera Brasil, do Instituto Ayrton Senna, também não poupa os professores. "Mesmo na quinta série, eles têm que saber alfabetizar. Não podem colocar a culpa só no sistema de avaliação, na família, no governo. O 7 problema não está no sistema." Para ela, o professor se encontra num estágio de "solidariedade inoperante". "Eles se sentem impotentes para resolver o problema e acham que a solução está fora de seu âmbito. Não se sentem responsáveis." Alguns pais discordam. Maria de Lourdes Passos, 42 anos, irmã de um professor, diz ter brigado muito numa escola estadual do Grajaú, na periferia da zona sul paulistana, para que seu filho, William, dez anos, fosse reprovado. "Eu o segurei em casa para ele repetir a quarta série por faltas. Senão, ele ia continuar sem saber nada." Até há seis meses, o menino não lia nem escrevia, segundo a mãe. "Agora, ele está aprendendo", orgulha-se.

O caminho a ser percorrido, entretanto, não vai ser fácil para esses estudantes. Principalmente para quem viveu na rua, cheirou cola, praticou furtos e foi interno da Febem, como J. H. T., 14 anos, aluno da quarta série numa escola municipal. Ele lê muito pouco e praticamente não sabe escrever. Indignado, chegou a ameaçar professores por causa disso.

8 "Sem ler, não dá nem para ganhar uma mina (garota)", constata J. Duas professoras prometeram ajudá-lo fora do horário normal de aulas. Roberto e seus irmãos também esperam um futuro mais promissor. O pai deles morreu de cirrose no ano passado. A mãe, com Aids, faleceu logo depois. Iam ficar sob os cuidados do Estado, mas foram socorridos por uma vizinha, a analista de sistemas Josilay dos Santos, que conseguiu a guarda deles na Justiça. Os meninos estão instalados num quarto-e-cozinha alugado pela providencial protetora. Roberto 
sonha ser um jogador de basquete. "Quero ajudar meus irmãos." A parte mais difícil dessa lição, agora, deve ser aprendida por aqueles que comandam a educação no País. Eles deveriam saber que miséria e boa educação são coisas incompatíveis.

Texto 2: Ensino reprovado - publicado em 10/05/2000 por Gilberto Nascimento - ISTO É

Disponível em http://www.terra.com.br/istoe-temp/1597/educacao/1597ensino.htm. Acessado em 09/2016

Inicialmente, devemos olhar para o lide ${ }^{13}$ (trechos 0-1 e 0-2), que já aponta para os caminhos pelos quais o texto seguirá. Logo no início, o texto é apresentado como uma mera transmissão de informações, de modo que a interpretação pareça óbvia. Entretanto, analisando com mais cuidado, alguns aspectos chamam a atenção. Primeiramente, a ordem inversa do período transfere todo o foco semântico para o adjunto adverbial de modo "Sem repetência" (0-1). Trata-se da maneira como os alunos chegam até a sexta séria. Observa-se, contudo, que o Adjunto Adverbial é um termo acessório da oração (AULETE, 2015) e, portanto, não faz parte do núcleo de significação da sentença, cujo foco está no verbo e, neste caso, no verbo "chegar". Assim sendo, um Adjunto Adverbial acrescenta características ao verbo, modificando-o sem, contudo, ser o centro semântico. Vejamos como ficaria a mesma sentença sem o adjunto:

- Alunos de escolas públicas chegam até a sexta série sem saber ler, escrever nem fazer as quatro operações aritméticas.

Vê-se que a retirada da expressão "Sem repetência" passa, ao menos inicialmente, a ideia de que se trata apenas de uma informação. Evidencia-se, dessa maneira, que a sintaxe é um dos elementos centrais no processo de construção dos sentidos. As palavras não estão arranjadas de forma aleatória numa frase, mas a colocação de um elemento de uma forma ou de outra, num lugar ou noutro tem consequência direta na interpretação do texto, isto é, produzem diferentes efeitos de sentido.

Pensando em formação de famílias parafrásticas (PÊCHEUX, 1995; ORLANDI, 1999), pode-se ter a sentença acima construída de outras formas, como no seguinte exemplo:

- Alunos de escolas públicas chegam sem repetência até a sexta série sem saber ler, escrever nem fazer as quatro operações aritméticas.

Ao colocar "sem repetência" na posição sintática original do adjunto adverbial, percebe-se a referida expressão exprime exatamente a ideia de modo, isto, é o modo como os estudantes chegam até a sexta série sem, contudo, ser o centro semântico da sentença. Dessa

13 "Palavra aportuguesada do inglês 'lead', conduzir, liderar. O jornalismo usa o termo para resumir a função do primeiro parágrafo: introduzir o leitor no texto e prender sua atenção" (http://www1.folha.uol.com.br/folha/circulo/manual_producao_1.htm, acessado em 31/07/2016). 
maneira, "sem repetência" é apenas mais um elemento na cadeia sintática do período, não no sentido de significar menos, mas de não estar colocado como foco na interpretação. A sentença segue a ordem sujeito, verbo, complemento (nesse caso, adjuntos adverbiais). Assim, temos que alguém (Alunos de escolas pública) chega a algum lugar (até a sexta série) de algum modo (sem repetência e sem saber ler, escrever nem fazer as quatro operações aritméticas).

Por outro lado, se considerarmos o texto em sua forma original, temos que a locução "sem repetência" tem seu leque de possibilidades de significação ampliado. Isso ocorre porque o adjunto adverbial possui um caráter circunstancial. Ao compararmos as duas possibilidades de formulação da sentença, é possível perceber que, ao deslocar a locução adverbial para o começo da frase, embora ainda permaneça o sentido de modo, indicando a maneira como os alunos chegam à sexta série, é possível argumentar que "sem repetência" também passa a ideia de causa, isto é, aquilo que provoca uma outra situação. Novamente recorrendo às famílias parafrásticas, temos o seguinte:

- Já que não há repetência, alunos de escolas públicas chegam até a sexta série sem saber ler, escrever nem fazer as quatro operações aritméticas.

Percebe-se, a partir da comparação das diferentes formulações apresentadas, que a locução adverbial "sem repetência" não tem um modo único nem tampouco explícito de interpretação, podendo ser considerada o modo como os alunos chegam à sexta série bem como a causa de chegarem à sexta série sem saber ler, escrever ou fazer as operações matemáticas. Essa dualidade, embora esteja mais explícita neste trecho, faz parte do funcionamento da linguagem. Entretanto, o deslocamento do adjunto adverbial provoca uma inquietação na compreensão do texto, de modo que os dois caminhos são possíveis.

Para além disso, o efeito de sentido causado pelo descolamento da locução adverbial para o início da sentença indica, de alguma forma, que a repetência deve ser o centro do processo educacional. Uma centralidade sintática que leva a uma dualidade semântica e, como consequência, uma concepção de educação que passa necessariamente pela reprovação como elemento regulador da qualidade do ensino nas escolas públicas brasileiras.

Observa-se, no entanto, que as duas formas de interpretar a locução adverbial levam a um mesmo ponto, isto é, ao fato de que a reprovação deve fazer parte do sistema educacional como garantidor mínimo de qualidade. Se consideramos "Sem repetência" como indicativo de modo, o sentido do trecho 0-1 e 0-2 fica centrado no fato de que não somente os 
alunos chegam à sexta série com algum tipo de defasagem (na escrita, na leitura, na matemática), mas o percurso é perpassado pela ausência de reprovação, fato que, para o autor, deve ser mencionado. Portanto, ainda que seja considerado como indicativo de modo, o adjunto adverbial em questão se coloca como elemento de extrema relevância para o entendimento do texto que se segue, sobretudo por estar descolado para o início do período. Por outro lado, se considerarmos como indicativo de causa, podemos perceber que "Sem repetência" se configura como o motivo pelo qual os alunos chegam à sexta série com as defasagens mencionadas anteriormente. Assim, é o fato de não haver repetência que diretamente causa o fracasso dos alunos ao longo dos anos.

Como se vê, a obviedade do texto é resultado do trabalho da ideologia no processo de construção de sentidos, criando, assim, a impressão de que haveria somente uma maneira de organizar uma frase ou um texto. O impacto na circulação dos discursos sobre as questões educacionais se dá no fato de que a reprovação é colocada como a causa e, ao mesmo tempo, como solução para os problemas da educação brasileira. Na argumentação defendida no texto, se a escola pudesse reprovar, os alunos aprenderiam.

Dessa forma, Gilberto Nascimento, sem explicitar trabalha o tema "repetência" no centro da sua argumentação. As falas selecionadas para a matéria, os exemplos, enfim, tudo gira em torno desse tópico. É interessante, contudo, notar que o contraponto da reprovação, a progressão continuada, só é abordada no parágrafo cinco (5-2 e 5-7) e, apesar de ser abordada de forma positiva, vê-se que a ênfase dada à reprovação (e os temas correlatos) é desproporcionalmente maior.

Dessa forma, os parágrafos 6 e 7, de forma mais contundente, abordam a questão da repetência apontando explicitamente os aspectos negativos de tal prática. Além disso, há um destaque na responsabilização do professor no que se refere ao fracasso dos estudantes. Porém, o discurso está em direção oposta em relação ao texto propriamente dito, pois a análise mostra que a argumentação, de forma não explícita, sustenta, de alguma forma, a necessidade da reprovação e que os professores têm uma grande contribuição para os péssimos resultados dos alunos da rede pública.

Assim, de 6-1 até 6-5 a temática central é a atuação docente. Interessante notar que a argumentação utilizada para dar voz ao professor tem sustentação na ideia da reprovação como instrumento capaz de imprimir qualidade ao trabalho pedagógico, pois, segundo o texto, os professores Dizem que hoje não podem "reprovar ninguém” (6-2, 6-3). 
Dessa forma, conforme o artigo apresenta, o drama dos alunos apresentado logo no início do texto (parágrafo 1) é fruto da impossibilidade de reprovar os estudantes. A voz dos professores, segundo este artigo publicado na Revista Isto É, clama por reprovação como instrumento pedagógico para solucionar as dificuldades dos alunos. O mesmo argumento utilizando anteriormente é repetido, isto é, se os professores fossem autorizados a reprovar, a educação brasileira não estaria em situação tão precária.

Na sequência do parágrafo (de 6-8 a 6-13) é a fala da Secretaria Estadual de Educação que prevalece. Assim, é preciso observar que o texto, de fato, aparenta trazer a voz do professor, apresentando-o como indignado com a situação, mas, a partir da análise discursiva, percebe-se que, na verdade, o professor é colocado numa condição extremamente desconfortável na medida em que só vê na reprovação a possibilidade de solução dos problemas educacionais e, além disso, a voz da Secretaria Estadual de Educação é a que fecha o parágrafo, de modo que se torna a opinião final em relação ao tema. Portanto, os professores querem, segundo o texto, o direito de reprovar os alunos como medida pedagógica e, além disso, o comando da educação no estado de São Paulo joga inteiramente a responsabilidade sobre o professor, pois o Estado já ofereceria as condições financeiras adequadas para os professores executarem a função de ensinar. No fim das contas, o professor é o culpado pelo fracasso dos estudantes.

No parágrafo 7, novamente, Gilberto Nascimento apresenta o que ele chama de "polêmica". Neste trecho, o autor procura mostrar que os professores estão acomodados no que o texto chama de "solidariedade inoperante", sempre jogando a responsabilidade para o sistema ou para alguma situação que não estaria na sua alçada. Na sequência, no trecho 7-7, o texto parece sinalizar com a possibilidade de defesa dos docentes, apresentando uma opinião de um pai que, segundo o autor, discorda dessa visão. Contudo, o texto cita uma mãe de aluno que, conforme a matéria, é "irmã de um professor". O que seria a defesa do professor, mostra um total apagamento de sua verdadeira função e, novamente, coloca-se a reprovação como o instrumento pedagógico por excelência. Conforme o relato (de 7-7 até 7-12), a mãe fazia com que o filho não fosse para a escola de modo que, ao final do período letivo, ele estivesse reprovado pelo número excessivo de faltas. O relato é concluído com a mãe dizendo que "Agora ele está aprendendo".

É preciso ponderar, contudo, que o texto, em momento algum, afirma que o aluno aprendeu porque as estratégias pedagógicas dos professores mudaram, mas, apenas, porque o 
aluno reprovou. Assim, embora o autor indique que a mãe discorda da ideia de que o professor é o responsável pelo fracasso dos alunos, sobretudo quando diz ela é irmã de um professor, o que lhe conferiria autoridade para defender a classe, o discurso afirma o contrário. Isso pode ser confirmado se analisarmos a fala da mãe com mais atenção, principalmente quando afirma que, caso não reprovasse, "ia continuar sem saber nada". Ora, se não sabia nada e estava na escola é porque não havia quem o ensinasse de forma adequada. Portanto, mesmo explicitamente dizendo que a mãe do aluno fazia um contraponto em relação ao trecho anterior (de 7-1 a 7-7), o discurso continua a reforçar que os professores não sabem ensinar e, além disso, a escola dependeria do mecanismo da reprovação para que os alunos alcançassem algum grau de aprendizagem.

Portanto, a análise deste texto revela que o que é dito nem sempre é o que de fato se apresenta e, quando se fala que a Análise de Discurso pretende permitir leituras de mundo menos ingênuas, é justamente para mostrar que um texto pode perfeitamente afirmar que sai em defesa dos professores, mas o discurso efetivamente caminha em outra direção e deriva para outros sentidos não necessariamente pensados pelo autor, movimento tal que faz parte do processo de construção de sentidos e é o que garante que mudanças podem ocorrer, na medida em que sempre se pode fazer uma outra interpretação, sempre os sentidos podem se mover para outros lugares diferentes daqueles previstos inicialmente pelo autor. Não significa, porém, que o texto seja um aglomerado de sentidos aleatórios. Ao contrário, possui uma intencionalidade (não absoluta), de modo que o sujeito leitor, a partir das formações discursivas às quais está filiado, pode significa texto de modos diferentes em função da posição discursiva que ocupa. 


\subsection{Escolas de referência como modelo de sucesso escolar}

Nas próximas seções serão analisados os textos cuja temática está relacionada à do grupo anterior, contudo, apresenta outras questões, como o papel central do processo de repetência com a exclusão escolar. Nesse processo, destaca-se a ideia de que há modelos de escolas que poderiam ser replicadas para outras instituições escolares.

O objetivo da análise é perceber como os discursos sobre as escolas de referência são construídos, quando se leva em conta um ambiente excludente sobretudo pela relevância dada à reprovação como balizadora do funcionamento desse tipo de instituição.

\subsection{1 - Análise Discursiva do texto 3}

Na matéria "Uma escola para se inspirar", Thais Paiva aborda um assunto extremamente interessante do ponto de vista das possibilidades estruturais e pedagógicas de uma escola de São Bernardo do Campo, São Paulo. Trata-se de uma escola gratuita, fundada pelo imigrante italiano Salvador Arena, em 1989, com o intuito de ser uma escola que, de algum modo, servisse de modelo para o sistema de ensino público brasileiro (parágrafo 4). Evidentemente, não questionaremos tal proposta, pois boas práticas devem ser divulgadas. Entretanto, o modo que se dá essa exposição desse modelo é que será objeto de análise, uma vez que é possível perceber de que modo discursos, muitas vezes contraditórios, manifestamse no dizer sem que o sujeito autor, em muitos casos, se dê conta desse processo.

\section{Uma escola para se inspirar}

Localizado em São Bernardo do Campo, Centro Educacional da Fundação Salvador Arena traz currículo diversificado e investimento de 20 mil reais anuais por aluno

Cerca de 3 mil dólares (ou 10 mil reais) é o valor que, anualmente, o Brasil desembolsa para cada estudante matriculado na Educação Básica de sua rede pública. Para se ter uma ideia,

1 o valor corresponde a um terço do investido por aluno pelos países da OCDE (Organização para Cooperação e Desenvolvimento Econômico), segundo o relatório "Education at a Glance", divulgado pela entidade no final de 2015.

Em São Bernardo do Campo (SP), no entanto, uma escola totalmente gratuita chama a atenção por destoar enormemente desse panorama. Investe cerca de 20 mil reais por aluno ao

2 ano, quantia equivalente a praticadas por países com sistemas educacionais considerados de ponta como Alemanha, Japão e Reino Unido.

Mais: dos 2.500 estudantes ali matriculados, da Educação Infantil ao Ensino Superior, 
metade é oriunda de famílias com renda de até 1,5 salário mínimo. Resumindo, crianças e jovens vindos de contextos socioeconômicos vulneráveis tendo acesso a uma educação de primeiro mundo.

Criado em 1989, o Centro Educacional da Fundação Salvador Arena (CEFSA) foi desenvolvido para ser uma espécie de escola-modelo para as escolas públicas do País. Sua história começa com a vinda do imigrante italiano Salvador Arena que, chegando ao Brasil, fez

4 fortuna e tornou-se um dos maiores empresários do setor metalúrgico do País à frente da Termomecanica. Filho único e sem herdeiros, Arena viu na criação da escola uma forma de deixar seu legado e impactar outras gerações.

Iniciar os estudos na instituição é, pode-se dizer, uma questão de sorte. A entrada no colégio é realizada por meio de sorteio da Loteria Federal. Todo ano, 105 crianças ingressam

5 na instituição pelo sorteamento que segue alguns critérios. Do total, 25 são filhos de funcionários da Fundação Salvador Arena. Das 80 vagas restantes, 50\% são vagas sociais, isto é, destinadas a famílias que ganham até 1,5 salário mínimo.

O Ensino Médio, por sua vez, oferece 210 vagas. Se o aluno obtiver a média 7 do $6^{\circ}$ ao

$69^{\circ}$ ano, ele garante automaticamente sua vaga na etapa. Se não conseguir, concorre com a comunidade por meio de uma espécie de vestibular. Das vagas que são abertas para concorrência, novamente, $50 \%$ são sociais.

Além do investimento volumoso, outro diferencial da escola está na grade curricular ofertada, bastante diversificada. Aulas de agricultura, robótica, cerâmica, educação financeira,

7 modelismo, música e teatro são algumas das novidades que despontam no cotidiano escolar dos alunos do colégio. Fora o Ensino Médio, todos os outros ciclos funcionam em tempo integral.

"Desde a fundação da escola, houve essa preocupação de desenvolver mais do que as 8 competências cognitivas, para que os alunos se desenvolvam como seres humanos", explica Cristina Favaron Tugas, diretora pedagógica da Educação Básica.

Nas aulas de agricultura, por exemplo, a importância de plantar, colher, valorizar uma alimentação saudável e respeitar a natureza são questões norteadoras. "Com esse tipo de abordagem, fica mais claro para as crianças a noção de desperdício. Quando compreendem todo o processo por trás do alimento que chega ao prato delas, percebem que uma porção desperdiçada não é apenas um pouco de arroz sendo jogado no lixo, mas tempo e cuidado sendo desperdiçados", explica a diretora.

Além da estação agroambiental, um curral, uma cisterna, uma estação de tratamento de esgoto e um extenso pomar ajudam a dar essa visão holística. "As crianças participam da ordenha manual e mecânica das vacas. O leite é usado internamente na faculdade de Engenharia de Alimentos, onde vira queijo, sorvete. Há ainda palestras sobre os vários tipos de leite e os processos que os transformam nos produtos encontrados nos supermercados", conta Cristina.

A própria configuração da sala de aula tenta acompanhar as inovações curriculares ao fugir da disposição tradicional dos alunos enfileirados diante do quadro-negro e do professor.

11 "Estamos testando novas disposições. Há salas com as mesas organizadas em formato de X, outras com carteiras em duplas, em grupos. Enfim, estamos vendo quais modelos favorecem mais a aprendizagem compartilhada", explica Cristina.

A preocupação em pensar a arquitetura escolar não como um recipiente para os alunos, mas como um dos elementos influenciadores do processo de ensino-aprendizagem e da 12 convivência fica evidente nas bibliotecas do espaço, projetadas pelo arquiteto Edmir Perrotti, professor da Escola de Comunicações e Artes da USP e responsável pela implementação do conceito de biblioteca interativa em diversas cidades do Brasil.

Nas partes reservadas aos alunos da Educação Infantil e Fundamental I, prateleiras 13 baixas, condizentes com a altura das crianças, favorecem a consulta e pesquisa nos livros, 
revistas e outros materiais dispostos. Na parte coletiva, bancos que imitam uma pequena arquibancada permitem que todos os alunos enxerguem e participem da contação de histórias e outras atividades lúdicas. "Todas as nossas bibliotecas possuem uma infoeducadora, uma pedagoga que realiza o trabalho de mediação com os professores das demais disciplinas. Então se a professora de Língua Portuguesa utilizará o espaço, a infoeducadora a ajuda com indicações de livros, preparação do espaço para a proposta da aula, entre outras intervenções".

$\mathrm{Na}$ escola, os estudantes também recebem alimentação gratuita e dispõem de 14 programações culturais e esportivas que acontecem no teatro e nos complexos poliesportivo e aquático sediados dentro do terreno da instituição.

No Ensino Médio, saltam aos olhos o investimento feito nos laboratórios e na ampliação

15 da participação dos alunos com a incorporação de alguns conceitos de gestão democrática.

As salas elegem os alunos representantes que se tornam responsáveis por encaminhar as demandas dos colegas aos supervisores. "Para se candidatar tem de ter ficha-limpa, isto é, não pode ter infrações recentes", diz a diretora. A partir das demandas, é feita a deliberação em uma espécie de plenária. "Os alunos também fazem a avaliação dos professores e demais funcionários".

Cerca de $80 \%$ dos alunos que se formam na Educação Básica do centro vão para a 17 universidade, dos quais $60 \%$ para instituições públicas.

O CEFSA oferece também quatro cursos de Educação Superior: Administração, Engenharia de Alimentos, Engenharia de Computação e Engenharia de Controle e Automação.

18 Por ano, são abertas 80 vagas por curso, 40 no primeiro semestre e mais 40 no segundo. Destas, metade é destinada aos estudantes de famílias que ganham até 1,5 salário mínimo.

Os cursos ofertados foram escolhidos de acordo com o perfil econômico da região do ABC paulista, importante polo industrial do País. "Temos muitas fábricas instaladas na região. 19 Então é uma resposta às necessidades locais. Muitas empresas procuram estagiários e funcionários aqui e também nos solicitam para fazer o desenvolvimento de produtos por conta dos nossos laboratórios de ponta", conta Wilson Carlos da Silva Júnior, diretor acadêmico das faculdades.

Segundo o diretor, a empregabilidade dos egressos gira em torno de 96\%. "Também fazemos o acompanhamento da evolução socioeconômica dos nossos alunos. Podemos dizer que a grande maioria tem uma ascensão social significativa, cerca de $60 \%$ estão com renda de 3 mil reais mensais para mais. Uma ascensão que não só impacta a vida deles, mas também de suas famílias e comunidades", comemora Júnior.

Texto 3: Uma escola para se inspirar-publicado em 20/05/2016 por Thais Paiva-Carta Educação/Carta Capital Disponível em http://www.cartaeducacao.com.br/reportagens/uma-escola-para-se-inspirar/. Acessado em 09/2016

O lugar de onde falamos define, sem dúvida, o peso atribuído aos sentidos produzidos. Dessa forma, o professor falar de um lugar historicamente diferente da posição de aluno, de diretor, de agente público. Entretanto, se esses lugares fossem dados de antemão e, além disso tivessem um caráter imutável, qualquer mudança social ou pedagógica seria impossível ou aconteceria a muito custo.

Nesse sentido, um órgão de imprensa como a Carta Capital (especificamente aqui Carta Educação) que, assumidamente, tem uma posição política alinhada à esquerda, não necessariamente falará como esquerda em todos os momentos. Isso porque a falha é 
constitutiva do dizer (cf. ORLANDI, 1999) e, portanto, inevitável. Isso não significa que estão em dúvida quanto à própria postura política, mas, independentemente da vontade do sujeito, outros sentidos são movimentados, sentidos não pensados, não desejados e, inclusive, evitados pelo sujeito falante, mas que aparecem sem que se possa controlá-los. Esse é o movimento que garante que o panorama vigente seja rompido, isto é, a constante possibilidade de interpretações diferentes, novas é o que permite colocar transformações em curso.

O objetivo do texto é mostrar como é possível uma instituição que oferece ensino gratuito ter sucesso e, além disso, recebendo alunos mais pobres, um fator que, em geral, é tido como um elemento que prejudica o rendimento geral dos estudantes. Entretanto, quando analisamos o modo como a argumentação está construída, vemos que, na verdade, o modelo seguido por essa escola não seria facilmente replicado em larga escala, devido à natureza da instituição mantenedora da escola. O artigo, no entanto, busca relacionar o ensino oferecido pela Fundação Salvador Arena com o ensino público de um modo geral, buscando mostrar como este poderia se beneficiar do modelo adotado no Colégio Termomecanica, mantido pela referida fundação.

No parágrafo 3, a autora trata da quantidade de alunos atendidos pela instituição. Segundo a matéria, são "crianças e jovens vindos de contextos socioeconômicos vulneráveis" atendidos por uma escola que oferece uma "educação de primeiro mundo". Com isso, Thais Paiva defende que a escola pública brasileira só não é melhor por conta do baixo investimento do aluno, cerca de um terço do recomendado pela OCDE (Organização para a Cooperação e Desenvolvimento Econômico), conforme o parágrafo 1. A menção à OCDE é particularmente interessante se pensarmos que esse organismo internacional, geralmente, está associado às nações mais ricas, de modo que seus interesses podem não coincidir exatamente com objetivos globais, mas que estejam de acordo com os anseios dos países ricos que compõem o grupo. Nesse quesito, a Fundação Salvador Arena está no mesmo patamar de nações cuja educação é considerada de ponta (de 2-2 até 2-4).

Neste ponto, é possível perceber como o discurso mobiliza sentidos que, nem sempre, foram planejados. Ao colocar os países da OCDE como referência no investimento em Educação, os interesses do grupo de países ricos que compõem esse organismo não se alinham com uma visão de esquerda (embora existam outras), fazendo com que a contradição surgida desse movimento seja fundamental para o analista compreender como os sentidos são 
produzidos e como circulam na sociedade. Dessa maneira, o analista não pode considerar que a menção à OCDE seja apenas um exemplo ilustrativo. É preciso considerar que há diferentes formações discursivas sendo colocadas lado a lado de modo a criar uma tensão no discurso que produz determinados efeitos de sentido. Esse organismo internacional tem uma história e, consequentemente, ao definir como parâmetro do quanto se deve investir em Educação os números definidos por um relatório da $\mathrm{OCDE}$, o discurso esquerdista fica entrecruzado com uma visão imperialista, capitalista, colonialista que, nem sempre, é possível alinhar com uma visão mais libertária ou revolucionária.

É importante, contudo, ressaltar que não se trata de apontar a jornalista como alguém da direita "infiltrada" num veículo de imprensa de esquerda, mas mostrar que as regiões discursivas não possuem fronteiras explícitas definindo seus limites, mas são parte de um movimento fluido - necessário - essencial para o funcionamento do discurso. Tal movimento independe da vontade dos sujeitos, pois os sentidos surgem sem que pensemos neles ou queiramos sua presença. Assim, se a jornalista tem ou não consciência do que representa a OCDE não deve ser o foco da análise, mas como esses discursos são articulados no texto, de modo que se explicite as relações ideológicas que não estão evidentes numa leitura superficial.

Um outro ponto interessante nessa tentativa de fazer da Fundação Salvador Arena um modelo para o ensino público é quando se aborda a questão do acesso às instituições mantidas por ela. Este, no nosso entendimento, é um dos aspectos cruciais nesse funcionamento discursivo pois é o ponto nodal que estabelece a diferença de funcionamento em relação a uma escola do sistema público. Não é qualquer aluno que pode se matricular no colégio da Fundação, pois há um rigoroso processo seletivo: “A entrada no colégio é realizada por meio de sorteio da Loteria Federal" (5-1 e 5-2). Só o fato de haver algum tipo de seleção, de uma certa forma, inviabiliza a comparação pura e simples com uma escola do sistema público regular, em que não qualquer restrição para matrículas, ainda que parte dos alunos matriculados na escola da Fundação Salvador Arena seja beneficiada por "vagas sociais" (5-4 e 5-5).

Nesse momento, é preciso remeter ao título da matéria, Uma escola para se inspirar, pois é preciso refletir um pouco mais a respeito dessa inspiração. Como dito anteriormente, uma análise discursiva deve considerar o modo como diferentes formações discursivas são postas lado a lado no discurso, de modo a explicitar essas relações que, em 
função do funcionamento da ideologia, não ficam evidentes imediatamente. Dessa maneira, o fato da escola atender alunos de baixa renda, não faz dela a instituição democrática por excelência, até porque é preciso considerar que qualquer tipo de seleção, da mais rigorosa àquela mais simples, geram impacto nos resultados, pois toda seleção pressupõe, necessariamente, exclusão. Portanto, alguns não terão acesso aos benefícios ofertados. Por outro lado, no ensino básico público regular, não há nenhum tipo de seleção para o acesso, fazendo com que a escola tenha de aprender a lidar com todo e qualquer tipo de aluno, dos bons aos que apresentam mais dificuldades. Quando se coloca esse tipo de escola como um modelo a ser seguido, é preciso explicitar de que lugar está sendo posto instituições com essa prática. Se voltarmos para os sentidos mobilizados a partir da menção à OCDE, percebemos a mesma lógica de funcionamento no acesso à Fundação Salvador Arena, pois só os mais bem preparados podem fazer parte desse sistema, como fica claro no site da Fundação ${ }^{14}$, na seção destinada às perguntas e respostas:

- “18. Aluno reprovado pode participar do processo seletivo do Colégio? Não".

- “19. Aluno reprovado perde o direito da vaga no Colégio e na FTT? Sim.”

Dessa forma, funciona a meritocracia, pois somente alunos com um mínimo de rendimento positivo podem adentrar o sistema e permanecer nele. Diferentemente, o ensino regular, o sistema não pode negar uma matrícula seja qual for a situação do aluno e, no decorrer dos seus estudos, a escola não pode simplesmente descartar esse estudante, embora o faça disfarçadamente, quando permite que os alunos reprovem por anos seguidos e, como consequência, acabam evadindo do sistema. Entretanto, não há nenhuma determinação para que alunos reprovados sejam retirados e, em muitos casos, a escola consegue reverter o problema da defasagem, apontando soluções que fazem o aluno voltar a fluxo normal de estudos.

É preciso considerar que apontar uma escola como a da Fundação Salvador Arena como modelo para o ensino público não é tão simples quanto parece. Obviamente, não se pode negar o excelente trabalho realizado na instituição, sobretudo com uma proposta curricular diferente do ensino público regular e que tem seus méritos. Entretanto, é preciso considerar que esta escola e a educação pública não exercem o mesmo papel e, consequentemente, não podem estar numa mesma condição de comparação. Não se trata de simplesmente apontar qual é melhor, mas compreender que os caminhos percorridos não são

14 http://www.cefsa.org.br/contato/faq/, acessado em 02/08/2016. 
os mesmos. De forma semelhante, podemos pensar na falaciosa oposição entre escola pública e privada. Não é possível colocar numa mesma condição instituições com naturezas diversas, embora todas elas lidem com educação básica, não exercem a mesma função, na medida em que a Fundação Salvador Arena, bem como as escolas particulares, não lidam com o público em geral, mas com alunos selecionados, isto é, uma parcela de estudantes que já possuem um desempenho mínimo se considerarmos que não há repetentes entre eles. Em oposição, a escola pública regular tem de lidar com toda sorte de situação: classe comum inclusiva, integração reversa, classe especial, dentre outras particularidades.

É por isso que a análise deve considerar as formações discursivas como o elemento central nesse processo. Dessa forma, a autora, ao escrever numa revista que se assume de esquerda, também se filia a formações discursivas de esquerda. Entretanto, pelo fato de o discurso ser fluido e as formações discursivas não serem homogêneas e definidas independentemente das condições sócio-históricas, há, em muitos casos, entrecruzamento de formações discursivas, fazendo com que alguém de esquerda mobilize sentidos historicamente marcados pela esquerda e vice-versa. Portanto, ao defender esse modelo de escola como o ideal para o ensino público regular, a autora, consciente ou não, sinaliza que a escola ideal é aquela em que só os melhores alunos podem fazer parte. 


\subsection{2 - Análise Discursiva texto 4}

A matéria aborda a decisão do Colégio Pedro II, um dos maiores e mais tradicionais do Brasil, de abolir o jubilamento por excesso de reprovação, prática usual no colégio desde muito tempo. $\mathrm{O}$ foco da análise estará nas visões antagônicas de pais, alunos e especialistas em educação bem como, e este é o aspecto central, o modo como a repórter se posiciona sem falar qual é sua opinião.

\section{Colégio Pedro II, no Rio, decide manter alunos repetentes}

Escola acabou com o jubilamento de alunos reprovados em anos consecutivos; medida agradou professores, mas foi criticada por pais

RIO - O tradicional Colégio Pedro II, que integra a rede federal e é considerado um dos melhores do País, acabou com o jubilamento de alunos reprovados em anos consecutivos. A medida tomada pelo reitor Oscar Halac, em portaria publicada em 28 de abril, agradou professores e especialistas, mas recebeu críticas de pais de alunos e de ex-alunos. Eles temem que a qualidade do ensino caia com a permanência de estudantes despreparados.

"Abolimos o cancelamento da matrícula por fracasso escolar. O grande mote é termos mecanismos e processos que visem a preparar os alunos, em vez de nos livrarmos daqueles

2 que tiveram mais dificuldade para aprender. Aluno jubilado é despesa jogada fora", disse Halac. Em 2013, 175 alunos foram jubilados e no ano seguinte,164. O Pedro II tem 12.937 estudantes em 15 câmpus.

De acordo com o reitor, a intenção é melhorar o desempenho dos alunos que enfrentam dificuldades, com reforço escolar no contraturno e aulas de apoio para estudantes com 3 necessidades especiais. "Estamos buscando medidas que modifiquem as estatísticas de evasão escolar. Não é com jubilamento e exclusão que vamos nos firmar como escola de excelência. As escolas brasileiras precisam se firmar com inclusão. Ser tradicional não é manter práticas ultrapassadas", afirmou.

A decisão desencadeou críticas. "Nunca vi jubilamento como algo prejudicial. Ninguém era simplesmente excluído. $\mathrm{O}$ aluno era chamado, a família também, ele tinha chances de 4 recuperar. Só saía da escola quem realmente não queria nada. Agora esse aluno continuará em sala, desmotivando colegas e professores", afirmou Bianka Dias Castilho, mãe de um aluno do 2.o ano do ensino fundamental.

No Facebook, o ex-aluno Sidnei Barbosa atacou a mudança da regra. "Fui reprovado e, 5 depois disso, talvez por medo do jubilamento, me tornei um excelente aluno." Já Letícia Duarte parabenizou o reitor. "A função da escola é garantir o aprendizado sempre", escreveu.

Facilidades. O principal temor é que a qualidade de ensino caia e outras medidas facilitadoras, como redução da média para passar e aprovação continuada, sejam adotadas. A direção nega que os temas estejam em discussão. Halac informa, no entanto, que está em curso a "reestruturação" do Código de Ética. "A expulsão de alunos por questões disciplinares ainda está nas normas, mas é termo que precisa ser revisto. Há várias outras formas de punir faltas graves."

A professora Regina Coeli Macedo, dirigente da Associação de Docentes do colégio, criticou o reitor por não ter consultado a comunidade escolar, mas defendeu a medida. "Há

7 certa cultura de que a qualidade do ensino está vinculada à exclusão. A motivação de estudantes não pode se dar pelo medo de serem jubilados." 
Para Ângela Carvalho da Siqueira, especialista em políticas de educação, o fim do jubilamento tem a ver com as condições atuais de ensino. "Faltam professores, há greves, isso

8 pode interferir no aprendizado. Nem todos aprendem no mesmo ritmo. A decisão não é como negativa."

O jubilamento não é prática em unidades federais, como o Instituto Federal do Rio de Janeiro, de cursos técnicos, e o Coluni, colégio de aplicação da Universidade Federal

9 Fluminense (UFF). O Centro Federal de Educação Tecnológica (Cefet) jubila estudantes reprovados em dois anos consecutivos.

Texto 4: Colégio Pedro II, no Rio, decide manter alunos repetentes. Publicado por Clarissa Thomé, no Estadão, em $06 / 05 / 2015$.

http://educacao.estadao.com.br/noticias/geral,colegio-pedro-ii-no-rio-decide-manter-alunos-repetentes,1682588, acessado em 09/2016.

O texto é bem explícito em relação ao objetivo de mostrar que pais e alunos, de um lado e professores, a escola e os especialistas em educação de outro, estão em posições opostas. Além disso, é também notório que se procura mostrar que a decisão do Colégio Pedro II levantou um acirrado debate sobre o que de fato confere qualidade a uma instituição de enino.

Nesse sentido, logo no início do texto, afirma-se o Colégio Pedro II "é considerado um dos melhores do País". Se olharmos para os resultados obtidos pelos alunos nos exames externos, de fato estão entre os melhores. Entretanto, é preciso considerar que não se trata de uma escola integrante do sistema público de educação básica amplo. Dessa forma, nem todo aluno pode se matricular no Pedro II e, além disso, a permanência também só é garantida àqueles que mantêm um rendimento mínimo. Analisando o funcionamento da escola a partir dos mecanismos de acesso e de fluxo dos estudantes, é possível concluir que não existe equivalência com uma escola pública regular (municipal ou estadual), devido à natureza da instituição ${ }^{15}$.

Um outro ponto em relação ao fato de o Colégio Pedro II ser considerado um dos melhores do país é em relação à construção frasal propriamente dita, pois o verbo está no particípio, sem explicitação do agente da passiva. Dessa forma, alguém considera o colégio o melhor, mas não se especifica quem. Esse é o trabalho da ideologia por excelência, pois se cria a ilusão de obviedade, como se, de fato, todos soubessem que o Pedro II é um dos melhores do país, não havendo a necessidade, portanto, de explicitar quem tem tal opinião ou quais critérios balizaram tal consideração. Não se trata aqui de deduzir o que a autora pensou, mas a própria materialidade do texto (verbo no infinitivo sem agente da passiva) indica o

15 Para mais informações sobre o colégio Pedro II: https://www.cp2.g12.br/index.php 
apagamento do autor da opinião, fazendo o discurso flutuar numa região sem dono, mas, ao mesmo tempo, na boca de todos, como uma máxima universal.

Na sequência, o texto traz nos parágrafos 4 e 5 as opiniões de pais e alunos acerca do fim do jubilamento. Muito embora não tenham sido ditas pelo jornal ou pela jornalista, as falas foram coletadas, editadas e publicadas pelo jornal e pela jornalista. Assim, são elementos inseridos na discursividade do texto e, além disso, ainda que sejam filiadas a formações discursivas diferentes, ao ser inseridas na linearidade de um texto, compondo um todo que significa, as opiniões passam a filiar-se, também, às mesmas formações discursivas do jornal ou da jornalista, ainda que de forma tensa ou contraditória.

A primeira participação é da mãe de um aluno do $2^{\circ}$ ano do ensino fundamental (de 4-1 a 4-3). Um trecho em especial chama a atenção: "Só saía da escola quem realmente não queria nada" (4-2). É interessante observar que a reprovação está, na opinião da mãe, diretamente ligada ao "não querer nada". Não seria, no entanto, uma questão também pedagógica? Obviamente, há alunos com plenas capacidades cognitivas que, de fato, não estão com foco nos estudos, porém há que se considerar os estudantes que não conseguiram aprender no ritmo ou da mesma forma que os demais. Dessa forma, o processo de jubilamento não leva em consideração o porquê de o aluno ter chegado ao ponto de reprovar várias vezes, mas apenas considerava o fato consumado, isto é, determinado estudante reprovou seguidamente. A questão aqui não é discutir se a decisão da escola foi certa ou errada, mas perceber que existe a circulação de um discurso sobre a reprovação que penaliza o aluno pelo seu fracasso. A repetência seria apenas a marca visível de alguém que abriu mão da necessidade de se dedicar aos estudos, o que nem sempre é verdade. Há pessoas que não têm o ritmo de estudo da maioria e a escola, de um modo geral, não está preparada para situações que fogem do comportamento considerado padrão.

Nesse sentido, quando a autora apresenta a opinião de alguém especialista em educação (parágrafo 7), afirmando que "Há certa cultura de que a qualidade do ensino está vinculada à exclusão" (7-2), poderíamos pensar que, de forma mais profunda, a exclusão tem se tornado um elemento garantidor da qualidade. Além disso, é preciso questionar o que se entende por qualidade, uma vez que, no texto, parece uma categoria absolutamente óbvia. Os sentidos são determinados a partir das formações discursivas e, portanto, falar de qualidade no âmbito da gestão institucional mobiliza sentidos diferentes dos movimentos pelo especialista, pelo pai ou pelo aluno. Independente de qual o significado de qualidade, a seleção de alunos 
que podem se matricular e os mecanismos como o jubilamento são instrumentos reguladores. Não atender quaisquer alunos sob quaisquer circunstâncias limita o escopo da instituição e, consequentemente, produz mais controle sobre os processos pedagógicos e disciplinares, permitindo, assim, um resultado mais preciso, como num laboratório em que as condições são ideais para o funcionamento de um experimento. No caso de escolas municipais ou estaduais, não há nenhum tipo de regulação e as instituições têm de atender a todos os tipos de alunos e enfrentar qualquer tipo de situação, tornando muito mais difícil a tarefa de ensinar, uma vez que o ambiente quase nunca é controlado e as variáveis atuam de forma mais intensa, provocando constantes mudanças nos rumos desse tipo de escola.

Um outro aspecto importante a ser notado nos parágrafos 4 e 5 , diz respeito à identificação das pessoas. Como já mencionado, as palavras "retiram" seus sentidos das formações discursivas e, desse modo, é fundamental saber quem está falando, pois é a posição do sujeito que indica quais sentidos são mobilizados. Assim, três opiniões são mencionadas, sendo duas delas contra o fim jubilamento e uma a favor da decisão do reitor do Colégio Pedro II. As duas primeiras, que defendem a manutenção da expulsão dos alunos com sucessivas reprovações, além do nome de quem falou, identifica-se, também, se é mãe (4-3) ou aluno (5-1). Em relação à opinião de quem concorda com o fim do jubilamento, há apenas o nome (5-2). O que pode ser apenas um equívoco, um fato menor no texto pode, a partir de uma análise mais criteriosa, mostrar, na verdade, a posição do jornal ou da jornalista a respeito do tema. Há ausências que significam mais do que palavras escritas e, neste caso, ocorre isso. Assim, fica evidente quem está contra o fim dessa prática, uma mãe (que representa o conjunto de pais) e um ex-aluno, mostrando que jubilar alunos traz bons resultados. Entretanto, não se sabe se Letícia Duarte, que concorda com o reitor, é aluna, mãe de aluna ou ex-aluna e isso faria toda a diferença. Por isso, a linguagem pode ser usada para comunicar e para não comunicar, mostrando que as ausências, ainda que não intencionais, não são aleatórias. Não dizer de onde fala Letícia é dizer que sua opinião não é relevante, não está em consonância com as outras visões apresentadas.

A visão do jornal, embora não explicitada, começa a ficar mais clara a partir de elementos como a não identificação de quem emitiu uma opinião usada na matéria e a partir do que coloca a repórter Clarissa Thomé no trecho 6-1, em que numa espécie de subtópico chamado "Facilidades" é afirmado o seguinte: "O principal temor é que a qualidade de ensino caia e outras medidas facilitadoras, como redução da média para passar e aprovação 
continuada, sejam adotadas". Chama a atenção a expressão "outras medidas facilitadoras", que são a redução da média e a aprovação continuada. Se essas são as outras medidas facilitadoras, significa há mais medidas desse tipo. E quais seriam? Até esse trecho, o texto só menciona uma medida: o fim do jubilamento. Logo, para o jornal, encerrar tal prática é considerada uma medida facilitadora, como as outras já citadas. Não há a explicitação de um ponto de vista do órgão de imprensa ou da jornalista, mas ao mencionar as outras medidas, ela, necessariamente, remete a outros elementos, pois só existe o outro em função de um primeiro elemento, neste caso, o fim do jubilamento.

Vê-se que o discurso é constituído do que está escrito e do que não está colocado. Assim o esquecido o apagado significa da mesma forma ou até de forma mais impactante do que o que está colocado explicitamente. A análise discursiva não decifra o que está por trás ou nas entrelinhas, mas olha para a materialidade do texto, que dá as pistas para acessar o processo de construção dos sentidos. 


\subsection{ANÁLISE COMPARATIVA}

\subsubsection{Análise comparada dos textos 1 e 2}

O exercício da comparação é mais do que conhecer o outro. Trata-se, de forma mais abrangente, de conhecimento mútuo em que olhar o outro é lançar vistas sobre si próprio. No campo da Educação Internacional e Comparada, entretanto, a comparação de textos não está no seu escopo original (cf. BRAY, 2015) e, mesmo com uma abertura ainda maior no campo, a comparação textual ainda não figura como espaço consolidado. Percebemos, no entanto, que a comparação de textos é um movimento fundamental para a produção de novas práticas de leitura que, por consequência, pavimentarão o caminho para mudanças no âmbito pedagógico e social.

No caso específico dos textos analisados neste capítulo, a comparação se dá a partir das análises discursivas realizadas, em função das quais mapearam-se regiões discursivas em que os discursos se situam. Nesse sentido, podemos destacar que o discurso sobre a reprovação está presente nos quatro textos, com enfoques diferentes, mas com estruturas argumentativas, de certa forma, semelhante.

Os textos mais antigos (de 2000 e 2001, respectivamente) trazem a discussão acerca da "cultura da repetência". Em ambos os textos o discurso sobre a reprovação vem profundamente marcado pelo uso da reprovação como instrumento excludente nas escolas. Em “Arqueologia da reprovação" (Texto 1), percebe-se que a reprovação atinge especificamente a camada mais pobre da população, enquanto que no outro texto, "Ensino reprovado" (Texto 2), observa-se semelhante argumentação, mostrando que a escola que não reprova é ineficiente.

Percebe-se, analisando os discursos sobre reprovação nos textos analisados, que cultura da reprovação é uma denominação que não parece, segundo o texto 1 , ser uma denominação válida para a classe média, mas um instrumento que só funciona com alunos oriundos de famílias mais pobres. Por outro lado, o texto 2 não trata diretamente da relação entre pobreza e reprovação, mas mostra que alunos e professores de escola pública pensam no processo educativo necessariamente regulado pelo ato de reter alunos em massa. Dessa forma, embora seguindo caminhos diversos, observa-se que os altos índices de reprovação de que falam os textos, são artifícios regulatórios do processo de exclusão social. 
Há, portanto, nesses discursos sobre a reprovação, um imaginário que efetivamente funciona na linguagem, não apenas como uma figuração, mas como elemento constitutivo no processo de construção de sentidos. No texto 1, opera a ideia de que o maior número de pobres na escola é um dos fatos cruciais para a queda no rendimento da escola e que o medo de reprovar só tem sentido em camadas mais abastadas da sociedade. No texto 2 , o destaque vai para o fato de a matéria enfatiza falas que colocam a reprovação como instrumento pedagógico que sempre funcionou e, ao ser retirado da vida escolar, provoca um vácuo na relação ensino/aprendizagem.

Assim, embora sigam percursos diferentes, observa-se o imaginário sobre a reprovação aparece de forma muito semelhante em ambos os discursos, pois a retenção de alunos surge como o norteador das práticas pedagógicas, sobretudo a partir do medo que a reprovação gera nos alunos. Em ambos os textos ${ }^{16}$ há situações mostradas em que somente a adoção da reprovação foi capaz de produzir efeitos produtivos no quadro educacional. É por meio desse tipo de raciocínio que se chega à conclusão de que "Agora ele está aprendendo" (texto 2) e que "com medo das bombas e dos castigos" o jovem de classe média é aprovado. Significa dizer que o discurso sobre a reprovação, nesses textos, não pode ser simplesmente suprimida do quadro das estratégias utilizadas nas escolas, pois ainda funciona ${ }^{17}$ muito bem.

\subsubsection{Análise comparada dos textos 3 e 4}

Os textos Uma escola para se inspirar (texto 3) e Colégio Pedro II, no Rio, decide manter alunos repetentes (texto 4) - têm como temática comum a apresentação de escolas de referência como modelos de instituições bem-sucedidas. Observa-se, no entanto, que a argumentação que efetivamente sustenta o texto é, na verdade, o discurso sobre a reprovação, isto é, a retenção como o elemento regulador da qualidade da instituição, pois, no caso do texto 3 , alunos repetentes não têm a possibilidade de matrícula na instituição e, com relação ao texto 4 , a reprovação era o passaporte para a saída dos alunos com baixo rendimento.

Ambos os textos partem da premissa de que há escolas diferentes das demais que, de alguma forma, funcionam como modelos para as demais. Dessa forma, ao tratar o Colégio

16 Texto 1: trechos 8-1, 8-2, 8-3 e 8-4; Texto 2: de 7-7 até 7-12.

17 O verbo "funciona" refere-se ao fato de que produz efeitos de sentidos, isto é, não se trata apenas de uma estratégia que traz bons resultados, mas que, também, exerce um papel central na construção dos sentidos. 
Pedro II e a escola da Fundação Salvador Arena como instituições de excelência, os textos, nesse mesmo movimento, constroem um discurso sobre a qualidade, na medida em que os textos trazem critérios a partir dos quais é definida a noção de qualidade no ensino.

É interessante observar o lugar em que são colocadas as duas escolas, o espaço das escolas públicas, sem nenhuma distinção explícita em relação às outras instituições de educação básica da rede pública. Entretanto, quando se observa a natureza das escolas, os próprios textos apontam uma série de características que produzem um enorme distanciamento entre as escolas citadas nos artigos e as instituições públicas regulares, no quesito ligado ao acesso às matrículas e também em relação às condições sociais. Tanto em uma quanto na outra, o acesso não é livre, isto é, não basta querer entrar, é preciso, antes, passar por algum tipo de processo seletivo. Assim, as escolas têm mais característica de gratuitas do que de públicas, ainda que se argumente que qualquer um pode fazer a seleção, somente os aprovados poderão se matricular. Dessa forma, nem todos têm acesso às escolas e, portanto, descaracteriza o aspecto público.

Nota-se, contudo, que os discursos sobre as referidas instituições não focam muito nesse aspecto, tornando o texto difuso nesse sentido, procurando encaminhar a interpretação para uma relação igualitária entre o Colégio Pedro II e a Fundação Salvador Arena, o que de fato não existe. Dessa forma, é importante notar que o fato de os textos estarem publicados em veículos de imprensa não lhes garante que estejam lá exatamente para comunicar, mas também são influenciados pelo funcionamento ideológico, que busca gerar um efeito de transparência na linguagem, fazendo com que as escolas pareçam apenas mais uma entre outras. Quando se analisam os textos, porém, percebe-se que a limitação ao acesso via seleção já cria um importante filtro no quadro de alunos, criando, assim, a ilusão de que são escolas públicas de excelência. Não estamos, com isso, afirmando que não são escolas boas, mas se trata de uma questão mais complexa, que envolve a relação entre dito e não-dito no discurso.

Nessa linha, percebe-se de que se trata de discursos da qualidade que, na verdade, são replicados para a escola pública de um modo geral, pois diferentes mecanismos de exclusão são utilizados nas escolas do sistema público regular que se assemelham aos recursos que escolas que não atendem ao grande público, como as mencionadas nos textos. Dessa forma, ao igualar as escolas como se não tivessem natureza diversa, afirma-se, sem afirmar explicitamente, que esse tipo de escola é o ideal para todos, em outras palavras, a 
escola pública só não é de qualidade porque não adota as medidas excludentes de instituições como o Colégio Pedro II e a Fundação Salvador Arena.

Há, no entanto, nos discursos sobre qualidade da escola observados em ambos os textos, um elemento - o discurso sobre a reprovação - que atravessa a discursividade como um todo, tornando-se uma espécie de sustentáculo para os sentidos relacionados ao tema. Assim, embora os textos sejam construídos em torno da ideia de que se tratam de escolas cujo foco não está na reprovação, observa-se, de forma contrária, que há nos textos discursos que vão de encontro à ideia de que reprovar é um problema, como no texto 3 , cujo acesso é regulado pela repetência, pois alunos que já reprovaram não podem entrar no processo seletivo. Em relação ao texto 4, o enfoque é justamente no fim do desligamento de alunos em função de sucessivas reprovações, mas os personagens citados no corpo do artigo, lançam mão de um discurso que não concorda com o fim do jubilamento pois esta seria uma forma de garantir a qualidade da instituição.

Tanto em uma escola quanto na outra, embora os discursos particulares sobre qualidade não passem pelas mesmas questões, são marcadas pela mesma região discursiva, que podemos situar no espaço da reprovação como elemento regulador da qualidade educacional, ainda que explicitamente os textos sejam construídos para afirmar o contrário. $\mathrm{O}$ discurso sobre a reprovação está alinhado ao discurso sobre a qualidade, fazendo de um sinônimo do outro, isto é, uma escola que reprova é capaz de manter certo nível de qualidade ou, dito de outra forma, uma escola que não permite que alunos repetentes se matriculem consegue manter seu nível de excelência.

Trata-se de um dos efeitos ideológicos mais elementares, o de parecer transparente, evidente. No caso dos textos analisados, percebe-se que o discurso é construído em torno da quase obviedade da necessidade da reprovação como garantidor da qualidade na escola. O mais interessante é que a textualidade explicita a visão de que reprovar é ruim, mas a discursividade caminha em direção oposta. Dessa forma, é preciso ler não nas entrelinhas, mas na linearidade do texto, observando que um discurso sempre remete a outros, ditos e nãoditos. 


\subsubsection{Comparação dos discursos sobre reprovação e sucesso escolar}

Ao considerarmos os quatro textos em perspectiva temporal diacrônica, observamos que há um mesmo fio condutor na base dos discursos analisados, pois, embora os temas não sejam exatamente os mesmos, percebe-se que os discursos sobre a reprovação constituem o modo sobre o qual se baseia a noção de qualidade aplicada nos textos aqui analisados.

Dessa maneira, a partir de um recorte temporal diacrônico, podemos dizer que os discursos sobre a reprovação, de uma certa forma, constituem-se como uma formação discursiva, no sentido de que agrupam, numa determinada região do discurso, modos de falar sobre o tema, de maneira tal que, mesmo abordando assuntos diferentes em épocas diferentes, há uma certa consistência no modo de significar da palavra reprovação. Não significa, contudo, que os sentidos são absolutamente idênticos e que são imutáveis ao longo do tempo, mas, quando se trata de formação discursiva, há uma espécie de fio condutor que faz um jogo entre o mesmo e o diferente, entre o sentido que cristaliza e o que modifica, entre o efeito ideológico da transparência e da naturalidade com a transformação e a constatação de que os sentidos não estão postos de antemão.

No caso dos textos analisados, observa-se que os discursos sobre a reprovação funcionam, em cada matéria a seu modo, como garantidores do que se entende por qualidade, que, nessa ótica, é entendida como resultado de processos excludentes (a cultura da repetência, os processos seletivos, as opiniões contrárias ao fim do jubilamento). Do mesmo modo, falar no fim da reprovação é produzir discursos que vão na direção do fracasso, isto é, torna-se quase impossível a uma instituição de ensino ser qualificada sem um instrumento de regulação que, neste caso, é a reprovação.

Outro ponto importante é que o discurso sobre a reprovação está construído baseado na tensão entre o dito e o não-dito, entre a palavra e o silêncio. Quando tratamos desse tipo de relação em Análise de Discurso, não nos referimos a inferências do analista num sentido abstrato, mas é a própria concretude dos textos que nos informa a respeito dessas relações. É, assim, a partir do dito que podemos acessar o não dito, é a partir do que se diz que é possível chegar ao que é silenciado no discurso, pois, em muitos casos, o sujeito diz " $\mathrm{x}$ " para não dizer “ "y". Não é uma questão de comunicação no âmbito textual, mas de análise em termos discursivos. 
É, portanto, a referência às formações discursivas que permitem ao analista fazer a comparação dos textos analisados, pois a linearidade do texto, com temáticas particulares, veículos de imprensa diferentes, em épocas distintas, não permitiriam a comparação se considerarmos apenas a concretude textual. É preciso transcender para a esfera discursiva, que, resultado de trabalho teórico, permite ao analista interpretar os textos a partir da discursividade que emerge dos textos. A partir daí, enfim, podemos remetê-los a formações discursivas já existentes ou, em casos particulares, observar a constituição de novas regiões no discurso. 


\section{Capítulo 3}

\section{Por que o PISA se tornou referência nos discursos sobre sucesso/fracasso escolar?}

\subsection{Pisa 2000}

O primeiro grupo de textos deste capítulo tratam da primeira edição do Pisa, realizada em 2000. Os textos, porém, são de 2001, ano de divulgação dos resultados do exame.

O objetivo na análise de textos daquele período está na possibilidade de ver a construção de discursos que são considerados fundadores, uma vez que era a primeira vez que se falava/escrevia sobre tal tema. Assim, a análise discursiva focará nesse processo de construção desses discursos, procurando interpretar as diferentes estratégias de articulação com outros discursos e que, de alguma forma, foram o ponto de partida para se falar sobre o Pisa.

\subsection{1 - Análise Discursiva do Texto 5}

O texto do jornalista Gilmar Piolla foi publicado no Portal do Aprendiz, do UOL, em 12 de dezembro de 2001 e trata dos resultados do Pisa de 2000. O artigo faz um contraste entre o pouco impacto que o desempenho muito ruim dos estudantes teve na sociedade em relação a um possível fracasso que o Brasil poderia ter na copa do mundo do Japão e da Coreia do Sul, que aconteceria em meados de 2002. A conclusão é que um fracasso no futebol teria uma repercussão muito maior do que os números do Pisa divulgados pela OCDE à época.

\section{Poderia ser pior, Sr. Ministro?}

É quase unânime que a Seleção Brasileira está desacreditada para a Copa do Mundo de 2002, mas imaginemos o pior de todos os cenários: o Brasil vai à Coréia e perde de goleada os três jogos da primeira fase contra as temidas seleções da China, Turquia e Costa Rica. Além de voltar mais cedo para casa, a seleção canarinho fica em último lugar da classificação geral entre os 32 países participantes do mundial. Qual seria o impacto dessa "tragédia" nacional na opinião pública? Que tratamento seria dispensado aos jogadores, comissão técnica e dirigentes 
no regresso da delegação? Com certeza haveria pressões para mudar tudo no comando da CBF e da seleção. E é certo que o técnico pediria o boné antes de desembarcar no aeroporto do Galeão - ou pediria asilo por lá.

Pois o Brasil acaba de participar de uma "competição" internacional bem mais séria do que a Copa do Mundo e o resultado foi exatamente desastroso. Além de amargar o último lugar, ficamos longe do penúltimo colocado (México) e a anos-luz dos primeiros (Finlândia, Japão e Coréia). O vexame foi completo, acachapante, humilhante. Não serve de consolo nem a alegação de que o País não tem tradição neste "esporte," pois nos últimos anos cansamos de ouvir das autoridades brasileiras e dos experts de organizações internacionais maravilhas sobre nossos progressos. Falava-se até num novo milagre brasileiro - uma verdadeira "revolução," conforme anunciou recentemente uma prestigiosa revista brasileira (Veja, 12/9/01). Já estávamos quase certos do nosso sucesso internacional. E de repente, descobrimos que as expectativas criadas eram falsas. Ouro de tolo. Puro produto de marketing.

Afinal, do que estamos falando? Da educação, é claro. Para ser mais preciso, dos resultados do Programa Internacional de Avaliação de Alunos (Pisa), divulgado na última semana pela Organização para a Cooperação e o Desenvolvimento Econômico (OCDE). Por coincidência, desta "competição" também participaram 32 países - os 28 membros da OCDE e quatro convidados: Brasil, Letônia, Rússia e China. Este estudo comparado teve como objetivo avaliar em que medida os estudantes que se aproximam do final da educação compulsória adquiriram o conhecimento e as competências necessárias para participar integralmente na sociedade atual. Por isso, a avaliação foi feita apenas com estudantes de 15 anos de idade, independente da série cursada. O Pisa 2000 teve ênfase na capacidade de leitura e de compreensão de texto.

Nas 322 páginas do relatório "Conhecimento e competências para a vida: primeiros resultados do Pisa 2000", divulgado no último dia 4, não há uma única notícia boa sobre a educação brasileira. Só ruins. Comecemos pela pior de todas: o Brasil ficou em último lugar tanto na classificação geral quanto na que leva em conta fatores socioeconômicos, bem como na comparação que considera apenas os estudantes com mais escolaridade. Mas a "última colocação" diz pouco sobre o desempenho desastroso dos estudantes brasileiros. A escala de avaliação utilizada pelo Pisa associa o desempenho médio dos alunos com cinco níveis de proficiência. O Brasil foi o único a ficar no nível 1. Pior ainda: $23 \%$ dos estudantes brasileiros

4 não chegaram nem ao nível 1. São quase analfabetos funcionais. Somados aos $33 \%$ classificados no nível 1 , nada menos do que $56 \%$ dos estudantes brasileiros tiveram um desempenho abaixo de sofrível. O México, penúltimo colocado, teve $44 \%$ dos estudantes no nível 1 ou abaixo. No nível 1, os estudantes apresentam dificuldade para completar tarefas simples de leitura, como localizar uma informação ou identificar o tema principal de um texto. De acordo com o relatório do Pisa, os estudantes no nível 1 ou abaixo mostram graves deficiências no processo de alfabetização, o que prejudica a continuidade do seu aprendizado e compromete a possibilidade de que venham a se beneficiar de futuras oportunidades educacionais.

Os resultados medíocres obtidos pelo Brasil não envergonharam o ministro da Educação, Paulo Renato Souza. Ao contrário, ele disse que ficou satisfeito e surpreendido com o desempenho do Brasil, pois esperava resultados piores. Ainda completou: "Não é que o ensino seja ruim. É que há muita repetência." (Folha de S. Paulo, 5/12/01). Reação bem diferente teve o Secretário de Educação dos Estados Unidos, Rod Paige, que se declarou muito

5 desapontado com a performance dos estudantes americanos, que ficaram na média das demais nações industrializadas. E acrescentou: "Na economia global, estes países são os nossos concorrentes. A média não é suficiente para os estudantes americanos". (New York Times, 5/12/01, p.A21). Como se vê, as expectativas são completamente diferentes. Enquanto o ministro brasileiro se declara satisfeito com o pior desempenho entre os 32 países avaliados, seu colega americano manifesta profundo descontentamento com uma posição apenas 
intermediária.

A comparação com o futebol, na abertura deste artigo, não é original nem apropriada. O economista Cláudio de Moura Castro já disse em certa ocasião que se a população brasileira fiscalizasse a educação com o mesmo interesse com que acompanha a seleção e cobrasse responsabilidade dos dirigentes educacionais como cobra dos que comandam o futebol, a

6 escola pública seria outra. Hoje, diante do descrédito que cerca a seleção, esse argumento parece exagerado. Além da falta de originalidade dessa comparação, é claro que não devemos ver a educação como uma "competição". No entanto, avaliações internacionais, como o Pisa, tem justamente o objetivo de oferecer um parâmetro para que cada país participante possa comparar o seu desempenho em relação aos demais.

Nesta perspectiva, o resultado desta avaliação mostra o que os relatórios oficiais têm escondido: a situação da educação brasileira segue alarmante, a despeito de toda retórica sobre

7 as maravilhas operadas na gestão do ministro Paulo Renato. Assim, a grande contribuição que o Pisa trouxe para o Brasil foi mostrar que o quadro do ensino é muito, mas muito mais grave do que sugere o cenário róseo vendido pela propaganda oficial. Basta comparar o que diz o relatório do Pisa com os relatórios oficiais e press-releases divulgados pelo Ministério da Educação sobre os resultados do Provão, Saeb e Enem.

O Inep é uma instituição séria e competente. Seria irresponsável suspeitar que os resultados das avaliações nacionais sejam manipulados. O que ocorre, sim, é uma leitura capciosa, parcial e enviesada dos resultados de forma a apresentar um quadro menos negativo do que a situação real. A imprensa tem a sua parcela de responsabilidade por confiar, de olhos fechados, nas análises oficiais. Vai ao extremo, como fez a revista Veja, de deslumbrar-se diante dos números e de proclamar sem pejo: "Isso é uma revolução" (Veja, 12/9/01). Diante dos resultados do Pisa, caberia perguntar que revolução é essa que produz resultados tão catastróficos. É à luz dessa avaliação que podemos fazer uma releitura dos resultados do Saeb, provão e Enem.

Comecemos pelo Exame Nacional do Ensino Médio (Enem). Ironicamente - numa demonstração de urgência política e de falta de "timing" - os resultados do Enem/2001 foram divulgados um dia após a conspícua divulgação do relatório do Pisa 2000. A incongruência entre os resultados das duas avaliações não poderia ser mais chocante. Nem o pior adversário político poderia urdir uma trama que colocasse o ministro da Educação numa situação tão vexatória. Mas numa prova definitiva da sua capacidade de representar, Paulo Renato não corou em dizer que considerava os dados do Enem "positivos", mesmo quando estes revelam que a média caiu cerca de 10 pontos, numa escala de zero a cem, em relação ao ano anterior. Na prova objetiva, a média despencou de 51,85 para 40,6 e na redação, de 60,87 para 52,58.

A diferença é que na edição de 2000, participaram do Enem cerca de 352 mil estudantes, grande parte oriundos de escolas privadas (43\%), enquanto em 2001, com a isenção da taxa de inscrição, o exame contou com a participação recorde de cerca de 1,2 milhão de estudantes, a 10 grande maioria proveniente da rede pública (66\%). Para o ministro, foi o aumento da participação dos alunos de escolas públicas que decretou a pronunciada queda observada na média geral tanto da prova quanto da redação. Esta justificativa, é preciso que se diga, é sensata e rigorosamente correta. Basta comparar a diferença entre a média dos alunos de escolas privadas com a média dos alunos de escolas públicas. Mas o papel do ministro não é culpar a escola pública cada vez que aparece um resultado negativo.

A mesma desculpa já tinha sido usada para justificar a queda no desempenho dos alunos indicada pelo Saeb/1999, divulgado em dezembro de 2000. Na ocasião, o ministro Paulo Renato atribuiu a queda generalizada das médias em língua portuguesa e matemática à incorporação de alunos de baixa renda aos sistemas de ensino - embora não tenha encontrado uma justificativa plausível para explicar o mau desempenho da rede particular. - "Ganhamos a batalha da incorporação de alunos. Agora temos que ganhar a batalha da qualidade," anunciava o ministro (O Globo, 29/11/00). Os resultados do Pisa/2000 e do Enem/2001 revelam que, 
apesar de todo malabarismo retórico, não dá mais para esconder o sol com a peneira.

O Documento Básico do Enem anuncia, de forma solene, que o seu propósito fundamental é "avaliar o desempenho do aluno ao término da escolaridade básica, para aferir o desenvolvimento de competências fundamentais ao exercício pleno da cidadania" 12 (www.inep.gov.br/enem). Se a prova atende ou não este objetivo são outros quinhentos. Mas, adotando a premissa de que o Enem tem buscado avaliar o desenvolvimento de competências fundamentais, então os resultados não podem ser considerados "positivos" nem pelo mais celerado analista, quando mais pelo ministro da Educação. O que o Enem/2001 mostrou é que a imensa maioria dos alunos está concluindo o ensino médio sem as competências requeridas para participar ativamente da sociedade. O mesmo quadro foi traçado pelo Pisa.

Entretanto, a leitura oficial dos resultados do Enem, absorvida em grande pela mídia, mostra um quadro mais "positivo", para usar o eufemismo ministerial. A mágica para "dourar a pílula" é simples. Embora a filosofia do Enem seja avaliar competências fundamentais, o ministério da Educação e o Inep não querem correr o risco de definir qual seria o desempenho satisfatório correspondente ao "perfil de saída do aluno da escolaridade básica" (Documento Básico 2000). A definição de uma nota de corte implicaria em reconhecer que a maioria dos

13 alunos não demonstra ter adquirido as tais "competências fundamentais". Como alternativa, adota-se um critério frouxo, pelo qual considera-se 'regular' e 'bom' o desempenho variando entre 40 e 70 (numa escala de zero a 100). Assim, mesmo diante de uma média de 40,6\% na prova e de $52,58 \%$ na redação, o press-release do MEC trombeteia que $68 \%$ dos participantes tiveram desempenho de Regular a Bom (www.mec.gov.br/acs/asp/noticias). A falta de modéstia é ainda mais aviltante na página do Inep, que não hesitou em manchetear: "Desempenho dos participantes é melhor na redação: Cerca de $80 \%$ dos textos produzidos obtiveram médias acima de Regular" (www.inep.gov.br/noticias)

Um leitor mais desavisado poderia concluir: se o Enem mostrou que cerca de $80 \%$ dos alunos foram capazes de produzir textos "acima de Regular", então a situação do ensino vai bem, obrigado. Mas com que base aponta-se um quadro tão otimista se a média da redação foi tão baixa $(52,58)$ ? Simples: adotando um critério malandro pelo qual nota acima de 40 já é considerado um sucesso. Cabe perguntar: que escola séria neste país aprovaria um aluno com este nível de desempenho? Ou melhor: se a prova do Enem é elaborada para avaliar as “competências fundamentais", como considerar 'Regular' a 'Bom' menções entre 40 e 70 ? Na prova objetiva, $57 \%$ dos alunos tiveram desempenho entre Insuficiente e Regular - isto é, notas inferiores a 40 . Apenas $5 \%$ dos participantes obtiveram notas acima de 70 , classificandose na faixa de desempenho de Bom a Excelente. Na redação, 11\% dos participantes se situaram nesta faixa.

Este seria o percentual dos concluintes do ensino médio que demonstra dominar as "competências fundamentais" que o Enem se propõe a avaliar. Não é preciso dizer que a imensa maioria dos participantes que tiveram desempenho de Bom a Excelente no Enem, tanto

15 na redação quanto na prova escrita, veio de escolas privadas. São estes que vão ocupar a maioria das vagas nos cursos mais prestigiados das universidades públicas graças, em parte, ao resultado do Enem.

É interessante notar que o resultado da prova objetiva do Enem, na qual apenas 5\% dos participantes foram classificados de Bom a Excelente, é bastante consistente com o resultado do Pisa/2000, no qual apenas $4 \%$ dos estudantes brasileiros tiveram desempenho 16 correspondente aos níveis 4 e 5 de proficiência. Portanto, todas as interpretações dos resultados do Enem que vão além do reconhecimento de que apenas uma parcela ínfima dos concluintes do ensino médio possui os conhecimentos e as competências fundamentais "ao exercício pleno da cidadania" - para usar a linguagem diletante do Documento Básico do Enem - é puro diversionismo.

O mesmo diversionismo tem sido praticado em relação ao Provão. Todo ano, ao divulgar o relatório final do exame, o ministro bate na mesma tecla: os resultados indicam uma 
melhoria do ensino superior. É só conferir o anúncio dos resultados do Provão/2001, que deve acontecer nos próximos dias. Mas a retórica não esconde a verdade dos fatos. Dos 18 cursos avaliados no ano passado, apenas Odontologia teve uma média acima de 50 numa escala de zero a cem $(53,9)$. Em grande parte dos cursos, a média foi inferior a 30. Não custa lembrar que o Provão foi instituído para aferir os conhecimentos e competências adquiridos pelos 17 alunos em fase de conclusão dos cursos de graduação (Lei no 9.131, de 24 de novembro de 1995). As provas são elaboradas com base nos conteúdos mínimos e nas habilidades definidas pelas comissões de cursos. Segundo Cláudio de Moura Castro, o Provão é um teste "cuja formulação reflete uma indagação séria acerca do que o graduando do curso deve saber ao se formar" ("Provão: como entender o que dizem os números", Brasília: Inep, 2001, p. 8).

Mas, numa postura tipicamente 'tucana', o Ministério da Educação nunca enfrentou uma questão central: qual é o rendimento mínimo ou adequado? Em outros termos, qual seria o desempenho satisfatório numa prova que pretende medir o que se espera que os graduandos de cada área saibam. Por não ser referenciado em nenhuma definição normativa sobre padrão mínimo de desempenho, o Provão permite uma leitura "aberta", de acordo com o gosto do freguês. Citando mais uma vez Moura Castro, na melhor das hipóteses, o Provão distingue quem é melhor de quem é pior, mas não autoriza dizer que o melhor é bom nem que o pior é

18 ruim (p. 9). Ou seja, é uma avaliação por contraste que não responde se o ensino em cada área tem uma qualidade aceitável ou não. As médias sugerem, no entanto, de duas uma: ou as provas estão sendo mal elaboradas, exigindo mais do que os graduandos devem saber, ou a situação geral é mesmo muito ruim, quase calamitosa. A segunda hipótese é mais plausível e consistente com o quadro geral da educação básica.

O MEC insiste, no entanto em repetir o que já se tornou o seu mantra: o Provão é um indutor da melhoria da qualidade. O ministro Paulo Renato vai mais longe e afirma: "Na prática, ao criarmos o Provão, nós acabamos provocando um terremoto no sistema de ensino superior." (Revista do Provão, 2001, p. 21). O "terremoto" no ensino superior só aconteceu na retórica oficial. Na prática, o maior abalo sísmico do qual se tem notícia foi a greve de mais de três meses no sistema público. Enquanto alardeia a melhoria da qualidade, o MEC faz vistas 19 grossas à expansão desenfreada do ensino privado "caça-níquel", que acaba de inventar uma nova modalidade: o ensino-franchise, que se propaga pelo país como rede de fast-food. Ao podar as competências do Conselho Nacional de Educação, ampliando o poder discricionário do Executivo nas decisões sobre autorização de cursos e credenciamento de instituições, o Decreto no 3.860, de 9 de julho de 2001, abriu caminho para a regularização das universidades e centros universitários privados que abriram unidades fora do seu município-sede e até mesmo do seu Estado. Essa é a verdadeira "McDonaldização" do ensino superior em marcha.

A exemplo do que acontece na educação básica, na área de educação superior o único avanço real tem sido a expansão do sistema, pela mãos do setor privado. O Provão, como aferidor da qualidade, produziu mais marola do que resultados concretos. E continuará ${ }_{20}$ produzindo até que a retórica dê lugar a medidas concretas, pelas quais o ensino picareta se sinta realmente ameaçado. Até agora, apesar de todo barulho, nenhum curso foi fechado depois de seis edições do Provão, a um custo que acumulado de bem mais de R\$100 milhões. Os empresários do ensino privado já concluíram há muito tempo que o Provão não é nenhum bicho-papão e não representa nenhuma ameaça séria aos seus interesses. Ao contrário, nunca foi tão fácil expandir.

Voltando ao ponto inicial deste artigo, cabe sublinhar que não é só o problema de ficar em último lugar numa avaliação internacional. Como já disse, não se trata de competição - por mais que a educação venha sendo tratada como mera variável econômica, perdendo seu caráter humanista. $\mathrm{O}$ desempenho dos estudantes brasileiros foi catastrófico em comparação com seus pares de outros países. Não há outra palavra mais precisa. O ministro da Educação tentou

21 várias explicações para essa calamidade. De um lado, atribuiu a responsabilidade ao sistema educacional, que seria culpado pelas altas taxas de repetência e de distorção idade/série. O 
press-release divulgado pelo MEC repete o refrão: "o atraso escolar, provocado pelos altos índices de reprovação e abandono às aulas, é apontado como uma das principais causas do baixo desempenho dos estudantes brasileiros na primeira edição do Pisa" (www.mec.gov.br/acs/asp/noticias). Quem aponta esta causa? O ministro.

Se os altos índices de reprovação e abandono - e o seu sub-produto, que é o atraso escolar - não denunciam a má qualidade do ensino, conforme argumenta o ministro, então quais seriam as verdadeiras causas do insucesso escolar? Paulo Renato oferece uma resposta corajosa: o Brasil seria o pior em educação por que tem a pior distribuição de renda do mundo. O ministro lembrou, de forma apropriada, que o Brasil tem o maior índice de Gini justamente o indicador internacional que mede a desigualdade na distribuição de renda - entre os 32 países que participaram do Pisa 2000. Além disso, o Brasil teria o menor PIB per capita. Assim nossas condições sociais (desigualdade) e econômicas (renda per capita) seriam determinantes do nosso fracasso educacional. Não há como discordar do ministro num ponto básico: a pobreza, fruto de uma estrutura perversa de concentração de renda, é o maior limitador de oportunidades educacionais. Políticas redistributivas, como o Bolsa Escola, são apenas paliativos - sobretudo quando utilizadas com propósitos eleitoreiros, transformando o benefício numa esmola.

Mas redistribuição de renda nunca foi prioridade, de fato, do governo FHC. Ao contrário do diagnóstico traçado pelo ministro da Educação para justificar o fisco do País no Pisa, o governo tem insistido que é a educação que vai melhorar a distribuição de renda e reduzir a pobreza. Agora, Paulo Renato sugere o contrário: sem melhorar a distribuição de renda do País, a escola vai continuar reproduzindo o insucesso escolar. As contradições são gritantes. Recentemente, quando o Unicef e o Ipea divulgaram o relatório sobre Desenvolvimento 23 Humano, a educação foi apontada como um dos fatores que mais contribuíram para a elevação do IDH. Entretanto, o critério utilizado é puramente de cobertura escolar, sem maiores apreciações sobre a qualidade do ensino. Na retórica oficial, a educação estava desenhando um novo quadro social. Vale aqui citar o mimo do presidente Fernando Henrique ao seu ministro da Educação: "Paulo Renato está fazendo uma revolução silenciosa no Brasil. A revolução pela educação, que promove a verdadeira inclusão social pela igualdade de oportunidades de acesso do analfabeto ao saber, ao conhecimento e à cidadania"(Isto É, 27/12/00, p. 29).

Pelas declarações públicas dadas pelo ministro para justificar o desempenho medíocre dos estudantes brasileiros no Pisa e no Enem, ele não acredita no que diz o seu chefe. Ao contrário, reconhece que o governo tem vendido uma ilusão ao prometer a cura dos males sociais através da educação. O que Paulo Renato tem dito é que sem melhorar a distribuição de renda e minorar as desigualdades sociais, não tem saída. Com a palavra o ministro-candidato: 24 "O Enem reflete a exclusão social brasileira" (Folha on-line, 05/12/01). Enquanto isso, o presidente soberbo diz que "quando as pessoas dizem que o governo é neoliberal, eu rio. São pessoas que não entendem nada do mundo nem do Brasil"(Folha de S. Paulo, 05/12/01). Diante dos resultados do Pisa e do diagnóstico traçado pelo ministro, segundo o qual a desigualdade social é uma camisa de força que impede a melhoria da educação, a graça presidencial deveria dar lugar à indignação. $\mathrm{O}$ que este governo, que não aceita o carimbo de neoliberal por que tem um "setor de planejamento corporificado no "Avança Brasil"”, fez nos últimos sete anos para resolver a equação da distribuição de renda?

O ministro da Educação não foi confrontado com esta pergunta. Além das causas ligadas ao sistema de ensino - altas taxas de repetência e distorção idade/série - e das causas estruturais - desigualdade e exclusão social - foram apontados outros fatores deletérios que teriam influenciado o desempenho do Brasil no Pisa. O Inep alega que pode ter havido

25 imprecisões na tradução das questões da prova, o que teria dificultado a compreensão dos estudantes brasileiros e, por conseqüência, prejudicado o desempenho (Folha de S. Paulo, 5/12/01). Neste caso, como instituição responsável pela aplicação do teste no Brasil, o Inep estaria admitindo incompetência. Se o problema da tradução é ou não fundamentado cabe ao 
Inep esclarecer. O que poderia ser argumentado com mais plausibilidade é que esse tipo de teste carrega um inevitável viés cultural, o que poderia afetar a consistência dos resultados. Mas isso não valeria só para o Brasil.

O press-release do MEC faz outra afirmação descabida ao sugerir que, como grande parte dos adolescentes brasileiros de 15 anos ainda está matriculada no ensino fundamental, nossos estudantes teriam sido "avaliados com base em conteúdos que ainda não chegaram a estudar" (www.mec.gov.br/acs/asp/noticias). Essa justificativa é risível, pois o Pisa não é uma avaliação "conteudista", o que seria ridículo em um estudo internacional comparado, presumindo-se que cada país tem um currículo diferente. Como já foi dito, o objetivo do Pisa é avaliar tão-somente "literacy" em três áreas básicas: leitura, matemática e ciência. Não se trata de conteúdos do ensino médio, mas dos conhecimentos e competências básicas que se espera os alunos tenham adquirido ao se aproximarem do final da educação obrigatória, que coincide, na maioria dos países, com a idade de 15 anos. Explicar o fracasso é sempre difícil. Busca-se as desculpas e justificativas mais disparatadas. O ministro lembrou que esta avaliação reuniu apenas os países mais desenvolvidos. Nada mal, portanto, que o Brasil busque se comparar com o pelotão da frente. É bom lembrar que já em 1994, Fernando Henrique Cardoso afirmava: "O Brasil não é mais um país subdesenvolvido. É um país injusto."(Mão à Obra, Brasil, p. 9). Mais uma vez, cabe indagar o que o seu governo fez para mudar essa equação. Na educação, como acabamos de ver, continuamos tão subdesenvolvidos quanto entramos na era FHC.

Para justificar o vexame brasileiro, o ministério da Educação encomendou uma análise dos resultados do Pisa ao economista e especialista em educação Cláudio de Moura Castro. Além das causas já indicadas, ele aponta o atraso com que o Brasil passou a investir na universalização do ensino fundamental - meta que ainda está por ser alcançada, a despeito dos significativos progressos realizados nas últimas décadas. Os demais países incluídos no Pisa,

27 ao contrário, já universalizaram a educação básica há muito tempo. A única novidade na elite do ensino mundial seria a Coréia, que saiu de uma situação de atraso pior do que o Brasil, na década de 50, para torna-se uma das economias mais industrializadas e um dos países com escolaridade média mais elevada. Segundo Moura Castro, "naquele país houve um compromisso férreo entre famílias, a sociedade e o governo acerca da prioridade a ser dada à educação" (www.mec.gov.br/acs/asp/noticias).

Não é o caso de encontrar culpados pelo fiasco e de "fulanizar" o debate. Seria injusto atribuir ao ministro da Educação, embora ele esteja no cargo há sete anos, a culpa pelo desastre 28 no Pisa - da mesma forma que seria imerecido creditar-lhe mérito pelo aumento da cobertura da escolar, único avanço concreto do País na área educacional. A responsabilidade é coletiva. A vergonha é nacional.

O ministro, as elites políticas e intelectuais, as corporações da área educacional e a mídia estão por demais ocupadas com o problema das universidades para dar atenção ao dilema da educação básica. Quem se importa com a situação das escolas primárias e secundárias? Quem se importa com as Donas Carmosinas que "tiram leite de pedra", tentando ensinar em condições as mais adversas possíveis? Não há milagre no desempenho educacional da Coréia. Há, sim, décadas de investimento sério e continuado em educação básica. A lógica é simples: não se constrói um edifício sólido a partir do telhado. Ou se cuida das fundações - a educação básica - ou o edifício educacional desaba com o Palace II. O resultado do Pisa só confirmou o que já se sabia: nossa base é frágil, extremamente frágil.

Desculpe-me, Sr. Ministro, mas chega de cinismo de dizer que está satisfeito pois esperava resultados piores. Depois de sete anos no comando da educação, esta é a melhor resposta que o Sr. tem para a opinião pública brasileira? Vamos tratar a educação com mais seriedade e os brasileiros com mais respeito. Os resultados não poderiam ser piores. Que posição seria mais vexatória do que o último lugar, a larga distância dos que estão no final da fila? Como técnico da seleção, mesmo que o seu chefe fosse o Ricardo Teixeira, o Senhor já 
teria recebido cartão vermelho. Se não fosse por outra razão, por comemorar cinicamente mesmo perdendo de goleada.

Texto 5:Poderia ser pior, Sr. Ministro? - Publicado em 12/12/2001 por Gilmar Piolla no portal Aprendiz UOL Disponivel em http://www2.uol.com.br/aprendiz/n_colunas/g_piolla/id121201.htm. Acessado em 29/12/2015.

O objetivo desta análise não é focar na comparação entre futebol e educação nem na ideia, rechaçada pelo autor, de competição entre os países, mas no fato de que o Pisa é considerado no texto como a última palavra em termos de qualidade no campo educacional. Desse modo, analisaremos de modo o discurso sobre esse tipo de exame é construído em cima da total falta de questionamento acerca do papel desempenhado pelo Pisa na educação global. Portanto, focaremos em aspectos do texto que alçam o Pisa à condição de "gabarito oficial" da educação mundial, isto é, o fato de que se colocam os resultados do teste num patamar de espelho preciso da realidade, tornando-se, dessa forma, o criador de parâmetros qualitativos para os sistemas de educação dos países da OCDE.

No parágrafo 3, o autor traz uma primeira definição acerca do Pisa (de 3-4 a 3-6). Piolla o define como um estudo comparado que objetiva avaliar se os estudantes com 15 anos de idade "adquiriram o conhecimento e as competências necessárias para participar integralmente na sociedade atual" (3-5, 3-6). Um primeiro ponto a ser observado diz respeito à denominação "estudo comparado", que não é utilizada pelo autor para caracterizar o campo de estudo Estudos Comparados em Educação, mas se refere ao fato de que o exame da OCDE apresenta os resultados dos diferentes países participantes do teste em tabelas (cf. OECD, 2014), produzindo mais uma ideia de ranking do que alguma forma de comparação mais profunda. Essa forma de divulgação é o que faz o artigo relacionar o desempenho dos países a um torneio de futebol como a copa do mundo.

Nesse quesito, cabe questionar: a quem interessa ranquear os países? É preciso, inicialmente, colocar que as palavras significam a partir de formações discursivas e estas, por sua vez, são resultado de processos históricos. Dessa forma, só é possível compreender como funcionam os discursos sobre a OCDE se analisarmos sua história, que começa em 1948, com o surgimento da Organização para a Cooperação Econômica Europeia (OEEC, em inglês) ${ }^{18}$, com o objetivo de executar o plano Marshal, desenvolvido pelos Estados Unidos com o objetivo de prover recursos para os países aliados promoverem a reconstrução de uma Europa devastada pela II Gerra Mundial. Entretanto, somente em 30 de setembro de 1961 a

18 Fonte: http://www.oecd.org/about/history/, acessado em 07/08/2016. 
Organização para a Cooperação e Desenvolvimento Econômico (OCDE) foi oficialmente fundada. Observa-se, portanto, que o surgimento da OCDE se deu em meio a uma profunda fragilização do continente europeu, fazendo com que os interesses estadunidenses fossem aceitos, uma vez que, sem uma ajuda externa, dificilmente a Europa se reergueria de forma tão plena em um curto período de tempo.

Como consequência da ampliação da atuação da OCDE ao longo do tempo, o Pisa vem se tornando, nos últimos anos, o principal instrumento de avaliação internacional e, cada vez mais, configura-se como um dos parâmetros mais importantes na aferição da qualidade do ensino mundo afora. Justamente neste ponto se insere a discussão que propomos aqui, isto é, discutir como o discurso sobre a qualidade de ensino passa, quase que necessariamente, pelos resultados do Pisa.

Isso pode ser percebido na apresentação feita por Piolla dos objetivos do exame internacional: avaliar se os estudantes "adquiriram o conhecimento e as competências necessárias para participar integralmente na sociedade atual”. Primeiramente, é preciso questionar se o modo de participação na sociedade atual é o mesmo no Brasil, na China, nos Estados Unidos, no Japão ou na Europa. Além disso, não fica claro o que significa "participar integralmente na sociedade atual", pois há diversas formas de um jovem participar da vida em sociedade, a partir da vida profissional, dos estudos, do voto. Portanto, não existe uma forma padronizada de participar da sociedade nem mesmo dentro de um único país como o Brasil, em que cada estado possui características muito diversas em relação aos outros.

Observa-se, no entanto, que essa aparente obviedade é, na verdade, resultado do trabalho ideológico, fazendo com que não haja dúvidas acerca do significado de algo. Assim, é como se o discurso sobre o Pisa fosse óbvio e cristalino, como se todos soubessem que o exame tem tais objetivos. Por isso, em Análise de Discurso, afirma-se que a linguagem serve tanto para comunicar quanto para não comunicar (cf. ORLANDI, 1999), de modo que, embora o texto esteja claro e objetivo, o próprio funcionamento da linguagem pressupõe não transparência, errância dos sentidos e, assim, uma análise discursiva deve considerar que há como que uma névoa mesmo no mais cristalino texto, mesmo naquela situação em que os sentidos parecem ser o que de fato está dito. Entretanto, o que não está dito também funciona e poderíamos ter alguém posicionado à esquerda em termos políticos, defendendo (sem o fazer explicitamente) os interesses das nações capitalistas mais poderosas. 
Não significa, contudo, afirmar que o Pisa não serve como um parâmetro válido para se considerar, mas é preciso ter claro que não se trata do parâmetro por excelência, isto é, como se esse tipo de teste internacional literalmente fotografasse o estágio atual da educação de um país e, assim, fosse a perfeita tradução dos problemas ou sucessos enfrentados por determinado sistema educacional. Dessa forma, o discurso com o qual deparamos é o de que o mau resultado no Pisa mostrou, de forma líquida e certa, que se a educação brasileira vai de mal a pior, como se vê em 2-6, 2-7 e 2-8. Interessante notar que o discurso de afirmação trazido pelo Pisa (tanto relacionado ao sucesso quanto ao fracasso) não parece ser somente um fenômeno brasileiro, mas mundial, como se percebe em 2-4 e 2-5. Portanto, o Brasil parecia progredir em termos educacionais até ir mal no Pisa, que seria, segundo essa visão, o instrumento infalível capaz de mostrar o retrato atual de um país no campo da educação.

Podemos afirmar, portanto que o Pisa pode ser considerado um bom instrumento de comparação de desempenho entre países. Entretanto, é preciso entender como esse processo se constituiu, a ponto de se colocar esse tipo de exame como o parâmetro capaz de determinar se um país tem ou não uma educação de qualidade. Entretanto, o discurso não é plenamente controlável, isto é, ainda que o sujeito ache que o Pisa deveria ser tratado com cautela, que não se trata de competição, como várias vezes é afirmado no texto, sempre se escapam sentidos não pensados pelo sujeito, de modo que, independente do que o sujeito de fato pensa sobre o Pisa, o discurso aponta, de algum modo, para uma relação de hegemonia do Pisa como principal - ou único - indicador internacional de qualidade no campo educacional. 


\subsection{2 - Análise Discursiva do texto 6}

No texto "A lição de Pisa", publicado, em 2001, no jornal O Globo, discute os impactos que os maus resultados do Brasil no Pisa 2000 na educação do país bem como traz um sucinto panorama da realidade educacional brasileira a partir de alguns dados do Saeb de 1999, publicados pelo INEP.

\section{A lição de PISA}

Os resultados do Brasil no Programa Internacional de Avaliação de Estudantes, PISA lanterninha entre trinta e oito países, logo abaixo do México - não chegam a surpreender, mas ajudam a recolocar na pauta a questão da péssima qualidade de nossa educação. Os detalhes desta história já eram conhecidos, e estão analisados de forma pormenorizada no relatório do Sistema de Avaliação da Educação Básica para 1999, feito e publicado pelo INEP. Em Português, na 4a série da educação fundamental, todos os Estados brasileiros se encontram, na média, no nível inicial da aprendizagem, que vai de 150 a duzentos pontos, e no qual os estudantes são capazes de "leitura com compreensão localizada de textos pequenos, com frases curtas em ordem direta, vocabulário e temática próximas da realidade do aluno." Nesta escala, as médias dos Estados do Sudeste e Sul se aproximam dos 180; e a dos Estados do Nordeste estão abaixo de 160 (a média brasileira é 170).

Isto significa que quase metade dos estudantes da 4a série do Nordeste, e uma boa parte dos estudantes do Centro-Sul, estão abaixo deste nível mínimo. Ou seja, são analfabetos funcionais. Pior: entre 1997 e 1999, a média nacional parece ter diminuído, especialmente em

2 Minas Gerais, que já teve o nível mais alto do país. Ninguém sabe exatamente o que ocorreu a queda pode ter sido pode sido uma diferença do próprio teste, a má implementação da política de combate à repetência, ou quem sabe um certo desânimo nacional que tomou conta de nossas escolas. Em breve saberemos o que nos dirá o SAEB de 2001.

O que pode ser feito? As respostas usuais, já conhecemos: investir mais em educação, pagar melhor aos professores. Mas nosso problema mais sério não é que gastemos pouco, ou que nossos professores ganhem mal: o problema mais sério é que o ensino continua ruim mesmo quando gastamos mais, e os professores são bem formados. Os dados mostram que não gastamos tão pouco assim, e o nível dos professores vem melhorando. Segundo a OCDE, o Brasil já gasta cerca de $17 \%$ dos recursos públicos em educação, em comparação com 13 a $14 \%$ para o Canadá e França, e 16\% para o Chile. Pode ser que estes dados estejam

3 superestimados, mas eles mostram que dificilmente poderíamos mudar o patamar de gastos sem um crescimento significativo da economia. Em relação aos professores, 30\% dos que ensinam até a quarta série, e 40 a 50\% nas regiões Sudeste e Sul, têm nível superior, e ganham salários compatíveis com este nível para o mercado brasileiro. É certo que a situação de uma escola no Estado de São Paulo ou Rio Grande do Sul é muito melhor do que a de uma escola no interior da Bahia ou do Maranhão. Mas nem por isto a educação recebida pelas crianças em São Paulo é tão melhor assim. E isto que estamos falando somente da educação mais elementar. A situação do ensino médio, com a quase totalidade dos alunos em cursos noturnos seguindo currículos obsoletos, é ainda mais séria. Para dar um exemplo extremo, o desempenho dos alunos da $3^{\text {a }}$ série do ensino médio em Português em São Paulo despencou de 305 para 267 entre 1997 e 1999 (a média brasileira caiu de 290 para 266 no mesmo período). 
problema com uma série de programas de estilo e custos variados. No nível federal, a lista de projetos inclui, além dos sistemas de avaliação como o SAEB e o ENEM, o Programa Nacional do Livro Didático, de distribuição de livros; o Projeto Fundescola, de obras e equipamentos para as regiões mais pobres; o Programa Nacional de Biblioteca na Escola; o ProInfo, de introdução de tecnologias de informação nas escolas; a TV Escola; o Fundo de Manutenção e Desenvolvimento do Ensino Fundamental e de Valorização do Magistério; os Parâmetros Curriculares Nacionais para o Ensino Fundamental e Médio; o Programa de Aceleração de Aprendizagem; o Programa Dinheiro Direto na Escola; e o novo programa bolsa-escola. Seria absurdo e injusto concluir que, como a educação não está melhorando, estes programas são inúteis, e deveriam ser abandonados. Em muitos casos, eles têm um longo tempo de maturação, e são dirigidos por equipes competentes e dedicadas. Mas é ingênuo também acreditar que eles vão cumprir tudo aquilo que foi prometido e pensado no momento em que eles foram lançados.

O fato é que não existe receita mágica para os problemas da educação fundamental. Dez anos atrás, sabíamos pouco do que estava acontecendo, e todos diziam que era preciso construir escolas, educar melhor os professores e acabar com a evasão. Hoje, graças sobretudo ao trabalho do INEP, já temos excelentes dados, quase todas as crianças já estão na escola, os

5 professores se graduam nas universidades. Agora descobrimos que as crianças não aprendem, e tratamos de estabelecer programas os mais variados para corrigir os problemas que vamos encontrando. Mas ainda não aprendemos a avaliar os programas que existem, conhecemos pouco das experiências de outros países, assim como dos bons exemplos que existem em nosso meio. Falta uma cultura moderna e atualizada de estudos e pesquisas educacionais, que possa ir dando respostas e apontando caminhos nesta grande jornada que temos pela frente.

Texto 6: A lição de PISA - Publicado por Simon Schwartzman em O Globo, 12/12/2001.

Disponível em http://www.schwartzman.org.br/simon/pisa.htm, acessado em 09/2016.

A abordagem inicial do texto diz repeito ao fato de que o Pisa seria apenas a confirmação da situação de penúria pela qual passava a educação brasileira naquele período. Embora, segundo o texto, não tenha havido surpresa com relação aos resultados do Brasil no exame, "ajudam a colocar em pauta a questão da péssima qualidade de nossa educação" (1-3, 1-4). O ponto interessante a ser observado aqui é que se trata de colocar o Pisa como o principal critério qualitativo para a educação de um país. Assim, de 1-1 até 1-4, o autor coloca que, de uma certa forma, já se sabia que o sistema educacional brasileiro ia de mal a pior, contudo, é o Pisa que confirma. Ir bem ou não nesse teste internacional é decisivo para classificar a educação de um país em termos qualitativos.

Há, nesse sentido, um movimento que procura trazer para os diagnósticos na área educacional uma visão de qualidade a partir da quantificação. Dessa forma, ainda que a prova do Pisa não tenha questões com foco apenas no conteúdo, mesmo que haja algum foco no modo como o estudante desenvolve uma determinada resposta, ao mesmo tempo, não é possível negar que se trata, no fim das contas, de uma comparação de resultados quantitativos, uma vez que a divulgação é feita em forma de tabela, como um ranking semelhante às 
competições esportivas. Poder-se-ia questionar, dentro desse tópico, o fato de que a OCDE não tem como objetivo o simples ranqueamento dos países ou não se pretende com o Pisa apenas dizer qual país é melhor do que o outro, entretanto, os discursos, quando postos em circulação não podem ser "domados" de forma simples, isto é, o que o sujeito fala, está dito de um modo não de outro e, mesmo que faça ressalvas, ainda que ignore o fato de que suas palavras estejam sendo interpretadas de uma forma alheia à sua intenção inicial, o discurso já é propriedade sua, mas está sujeito às condições de produção a partir das quais novas interpretações são feitas.

Assim sendo, ao divulgar seus relatórios para o público em geral, a OCDE não tem como limitar as maneiras pelas quais o discurso sobre o Pisa circula na sociedade. Como consequência, a imprensa costuma dar um tratamento meramente competitivo aos relatórios da OCDE, fazendo uma leitura própria dos resultados. É a esse discurso que a maior parte das pessoas têm acesso, inclusive na área de educação. Desse modo, há sentidos particulares mobilizados nesse modo de circulação dos sentidos pois faz do Pisa não um indicador a partir do qual diversas questões podem ser pensadas, mas, ao trabalhar os resultados a partir de rankings, o parâmetro de qualidade passa a estar nas primeiras posições em detrimento de quaisquer outros elementos. Do mesmo modo, encontrar-se na parte de baixo do ranking, ou na "lanterninha" (1-2), é sinônimo de fracasso total. Qualquer outro critério qualitativo interno que não passe pelo Pisa, torna-se inválido, sobretudo no discurso ao grande público, como numa matéria para o grande público como a que estamos a analisar.

Quando se diz que o Pisa passa a ser o critério de qualidade por excelência, falamos, na verdade, de um modo específico de ver a educação, isto é, uma maneira de compreender o processo de evolução dos estudantes e do sistema educacional como um todo a partir da perspectiva dos exames em larga escala que, em última instância, seriam garantidores dos "retratos" da situação do Brasil com relação às questões educacionais. No próprio texto, a partir de 1-6, percebe-se que o Saeb é utilizado como avalista dos resultados do Pisa, de modo a sustentar que os números do teste internacional confirmam os exames nacionais, numa lógica de retroalimentação. Podemos afirmar, assim, que há uma certa lógica discursiva, uma vez que o conceito de qualidade gravita em torno dos resultados em testes desse tipo, como o Saeb, usado no texto como forma de "provar" que, de fato, o Pisa "mostra" os problemas da educação no Brasil. 
É importante observar, ainda, que essa lógica discursiva não fica restrita somente aos aspectos puramente pedagógicos ou de desempenho dos estudantes, mas se entende, também, para questões mais amplas como aspectos financeiros e administrativos da educação. No caso apresentado de 3-5 a 3-8, percebe-se que até os investimentos em educação têm como referência, os números apresentados pela OCDE. Dessa forma, ela torna-se o padrão referencial para o discurso que, invariavelmente, busca no organismo internacional a meta ideal para se atingir, como se sempre estivesse correta para o mundo inteiro em qualquer situação. Fica, assim, os sentidos relacionados ao funcionamento da educação de um país ficam direcionados para a OCDE, de modo que qualquer medida que esteja fora de seu raio de ação seja considerada equivocada.

O texto é concluído de forma emblemática porque, embora o autor tendo afirmado que os resultados do Pisa "não chegam a surpreender" (1-2, 1-3), no final diz que "Agora descobrimos que as crianças não aprendem" (5-6). Essa contradição não é puramente uma falha, mas é lógica discursiva procurando seu espaço no texto, manifestando-se sob a forma de contradição. Assim, embora textualmente seja afirmado que o Pisa só mostrou o que já se sabia, o final do texto afirma - sem afirmar - que, na verdade, é a forma de ver a educação pela ótica dos testes internacionais que permitiu ao Brasil "descobrir" que os estudantes não estão aprendendo.

Portanto, a educação brasileira conta, a partir dessa lógica, com as diretrizes de qualidade de um organismo internacional (neste caso, a OCDE). O início do anos 2000 viu surgir um dos primeiros movimentos de mundialização da educação, na medida em que os países participantes do Pisa começaram a colocar o futuro das políticas educacionais nos resultados do teste, na medida em a educação de um país só é reconhecida como sendo de qualidade se está entre as maiores notas no Pisa. Do mesmo modo, as nações que figuram no fim da lista são consideradas um fracasso em termos educacionais. 


\subsection{Pisa 2012}

Os textos deste grupo de análise têm como tema central o Pisa 2012 e tratam dos questionamentos que o exame tem provocado sobretudo no que se refere ao modo como os sistemas de ensino têm se moldado em torno do teste.

As análises discursivas têm como objetivo nesta seção ver como os discursos são construídos em torno do Pisa enquanto principal instrumento regulador da qualidade de um sistema educacional, isto é, só se tem qualidade quando os resultados no exame são bons, influindo diretamente nas políticas dos países sem uma avaliação mais ampla em torno do real estatuto desse tipo de teste no quadro educacional.

Pretendemos, dessa forma, compreender como os discursos se articulam no sentido de referendar o Pisa como principal parâmetro de qualidade do ensino de um país.

\subsection{1 - Análise Discursiva do texto 7}

$\mathrm{O}$ texto em questão mostra diversos argumentos que mostram o quanto o Programa Internacional de Avaliação de Estudantes (Pisa) deve ter seu impacto superdimensionado nos sistemas educacionais dos países que participam do teste. Segundo a matéria, vários especialistas em todo o mundo têm se insurgindo contra o Pisa no sentido de fazer com que seus resultados não sejam encarados como o retrato da educação mas como, somente, mais um indicador que deve ser considerado nas análises, porém não considerado $o$ único instrumento de avaliação.

O artigo publicado na revista Carta Capital traz, na primeira parte, um breve histórico do Pisa, mostrando como o teste foi ganhando força e adesões ao longo dos anos e, ao mesmo tempo, como se estruturaram as primeiras críticas direcionadas à legitimidade da OCDE em função da natureza da instituição na área econômica, seu foco inicial, mas que, nos últimos anos, vem se dedicando a outros setores e, de forma particularmente intensa, a área de estatísticas educacionais, tendo o Pisa como destaque. 


\section{Pisa em seu devido lugar}

Programa Internacional de Avaliação de Estudantes é questionado como norteador de políticas públicas

Quando a Organização para a Cooperação e Desenvolvimento Econômico (OCDE) começou a aplicar o Programa Internacional de Avaliação de Estudantes (Pisa) em 2000, com o

1 intuito de comparar "conhecimentos e habilidades" de jovens de 15 anos em diferentes países, causou breves protestos.

No primeiro anúncio, professores e acadêmicos lamentaram que uma instituição formada por economistas se pusesse a dizer o que os alunos deveriam saber, medisse isso com

2 uma única prova e comparasse contextos diferentes. Logo que os resultados saíram, os ânimos se acalmaram. A Finlândia, já mundialmente famosa por seu sistema educacional de alta qualidade, obteve a mais alta nota. Fazia sentido.

Com a aceitação, o teste trienal ganhou força. A cada edição há mais participantes e os resultados tornaram-se aguardados por imprensa e governos. Aos poucos as habilidades

3 contabilizadas numericamente passaram a ser o indicador de qualidade da Educação internacional mais conhecido. Nesse meio-tempo, estados da China tomaram conta das primeiras posições.

Na última prova, em 2012, a Finlândia caiu para $5^{\circ}$ lugar em Ciência, $6^{\circ}$ em Leitura, e $12^{\circ}$ em Matemática. O exame começou a motivar mudanças polêmicas em países como Reino

4 Unido e Estados Unidos, que alcançam só o meio da tabela de 65 países. Para um crescente grupo de educadores não faz mais sentido.

Em maio, um grupo de 83 pesquisadores e representantes de faculdades de educação, professores e pais de diversos países publicou carta aberta com o título "OCDE e o Pisa estão

5 prejudicando a Educação ao redor do mundo". Os acadêmicos pedem que o teste pare de ocorrer, ao menos no formato atual.

Entre os signatários estão especialistas em avaliação como Diane Ravitch, ex-secretária adjunta de Educação dos Estados Unidos, acadêmicos como Heinz-Dieter Meyer, professor de

6 Políticas Públicas em Educação da Universidade de Geórgia e o sociólogo Stephen Ball, da Universidade de Londres.

Os autores questionam a autoridade do organismo pautado em cooperação econômica para aconselhar sobre o assunto, como ocorre nos relatórios de divulgação do Pisa. "Ao

7 contrário de organizações das Nações Unidas como a Unesco ou o Unicef, que têm mandatos claros e legítimos para a melhora da educação e da vida das crianças ao redor do mundo, a OCDE não tem essa autoridade", criticam.

O texto publicado em veículos acadêmicos e no jornal britânico The Guardian culpa o ciclo trienal pela busca por soluções de curto prazo. "Ao enfatizar um espectro estreito de 8 aspectos da educação, o Pisa desvia a atenção de objetivos menos mensuráveis ou imensuráveis, como o desenvolvimento físico, moral, cívico e artístico, perigosamente estreitando nossa imaginação coletiva sobre o que a educação é e deveria ser."

A principal questão, no entanto, é o desvio do tempo de aulas para treinamento para a realização de testes. "Empobrece nossas salas de aula à medida que, inevitavelmente, envolve

9 mais e mais longas baterias de testes de múltipla escolha, mais receituários de aulas "prontas para entrega' e menos autonomia para os professores", conclui a carta.

O Brasil não foge à regra e também sofre efeitos do Pisa a cada resultado. Como está sempre entre as dez últimas posições - apesar de apontado pela OCDE como um dos países que mais evoluíram nos itens aferidos nos últimos três exames - é questionado e recebe

10 sugestões de políticas públicas. O teste também serve como modelo para avaliações nacionais. 
A Teoria de Resposta ao Item (TRI), que passou a ser usada no Exame Nacional do Ensino Médio (Enem) desde 2009, por exemplo, figura nas técnicas aplicadas.

O especialista em Avaliação e Políticas de Aprendizagem Luiz Carlos de Freitas, professor da Universidade de Campinas, reclama da influência do teste que, em sua opinião, tem ponto de vista estreito. "O Pisa está destinado a internacionalizar a política educacional segundo a ótica da OCDE, que é uma entidade que detém exclusivamente a visão das necessidades dos empresários. A função da educação não é exclusivamente preparar mão de obra. Há outras sociais que eles não têm qualificação para dimensionar", afirma.

Para ele, o Brasil deveria participar mais na definição da amostra de estudantes, procurar suas próprias bases de comparação e divulgar as insuficiências do teste em vez de se basear por seus resultados. "O próprio Plano Nacional de Educação referenciou suas metas nos exames do Pisa e há outras receitas educacionais que vêm junto com a filosofia do exame: privatização e meritocracia."

Nesse sentido, outro ponto apontado pelos acadêmicos internacionais é a participação de empresas que fazem parte do mercado que vende material didático a governos na elaboração da prova. "Para a execução do Pisa e de uma variedade de serviços de acompanhamento e

13 monitoramento, a OCDE abraçou o modelo de parcerias público-privadas e entrou em alianças com companhias multinacionais com fins lucrativos, que têm potencialmente ganhos financeiros derivados de déficits - reais ou percebidos - descobertos pelo Pisa", afirma o documento conjunto.

A brasileira Luciana Pölönen, formada em Letras pela Universidade Federal da Bahia, vê o exame a partir de um dos epicentros da polêmica, a Finlândia, onde vive desde 2008 e

14 atua como professora desde 2010. O governo finlandês afirma que a qualidade ainda é a mesma e justificou a queda de posições pelo não treinamento dos jovens para a realização de provas.

No país, testes padronizados só são aplicados a partir dos 18 anos, antes do ingresso no 15 ensino superior. "O sistema educacional aqui funciona por causa das diretrizes socioeconômico-político-culturais. É algo que não cai de um dia para o outro", comenta.

Ela também destaca que a lista de habilidades aferidas é curta perto da missão da escola. "O Pisa não mede toda a capacidade acadêmica e não considera as enormes carências em

16 fundamentos básicos anteriores à educação. A discussão deveria ser muito mais profunda", diz. Apesar disso, não é contra a medição. "Nenhum país que investe em educação deveria temer a prova."

O presidente da Associação Brasileira de Avaliação Educacional, Ruben Klein, que já apontou erros na amostragem do Pisa, também discorda da carta que pede o fim do exame. Ele foi um dos brasileiros que assinaram um documento em favor da continuidade da avaliação,

17 organizado pela OCDE em resposta ao pedido de mudanças: "Uma coisa é como os dados são usados e as imperfeições do teste. $\mathrm{O}$ erro é dos governos que tomam decisões precipitadas. Outra é não querer que se aplique nada. Os problemas são muito parecidos com os que se vê pela Prova Brasil. Temos de admitir que eles existem para buscar saídas”.

Empossado este ano como presidente do Instituto Nacional de Pesquisas Educacionais (Inep), o estatístico Francisco Soares também defende a permanência do Pisa, mas admite que

18 os acadêmicos internacionais apontam pontos importantes. "A escola não é uma máquina de ensinar. Há outras dimensões de conhecimentos que não são mensuradas ali. O monitoramento daquela dimensão, no entanto, é importante", afirmou.

Ele usa o exemplo da Prova Brasil para enfatizar seu argumento. "Nosso País tem enormes desigualdades. Acostumamos com elas e naturalizamos que um pode aprender e outro não. Acontece que a Constituição de 1988 dá o direito a todos e, se não monitoramos se isso ocorre, ela vira uma utopia. É preciso evidenciar o problema", diz.

Por outro lado, Soares concorda que há outros objetivos da Educação. "A escola não 
termina na instrução. Nesse momento é que cabe essa discussão. Você pode aprender a ler e ter o conhecimento matemático e científico diante de um computador. A escola tem pelo menos duas outras dimensões: a socioemocional, de habilidades não cognitivas, e a de valores. Um sistema educacional sólido terá um sistema de avaliação para monitorar o direito, mas não como motor da educação."

Soares diz que iniciou a implantação de duas medidas no Inep para minimizar a ocorrência de rankings e a ênfase a notas descontextualizadas. A primeira é fazer comparações que incluam fatores como renda, histórico, formação de professores e condições estruturais das escolas. "Quando você ordena apenas por um dado, está igualando e estamos dizendo que a

21 comparação deveria ser entre iguais", afirma. A segunda é explicar o que significa cada nota ou faixa de pontuação em que se encontram os estudantes. "Cada habilidade que for descrita ali precisa vir com dez exemplos de como isso é avaliado. Gastamos pouco dinheiro no que chamo de relevância pedagógica, e isso precisamos fazer." Ambas estão previstas para começar ainda em 2014.

Os países participantes do Pisa têm direito a sugerir questões que são analisadas por especialistas e depois colocadas aos demais. Nenhuma pergunta brasileira fez parte do exame

22 até hoje. Os itens são os mesmos aplicados no mundo todo, o Brasil faz a tradução antecipada, devolve para a OCDE, que vê se não houve mudança de conteúdo, e depois recebe as provas prontas para aplicação.

Para o presidente do Inep, o resultado em cada habilidade é justo. "O trabalho é muito detalhado, variações pequenas são corrigidas pela TRI.” Já classificar a Educação do Brasil em

$2355^{\circ}$ lugar (resultado de 2012 em Leitura), 58 (em Matemática), 59 (em Ciências) é injusto. "Está errado. Coloca uma dimensão moral em cima do dado."

Texto 7: Pisa em seu devido lugar. Publicada por Cinthia Rodrigues em Carta Educação no dia 05/08/2014 Disponivel em http://www.cartaeducacao.com.br/reportagens/pisa-em-seu-\%E2\%80\%A8devido-lugar/, acessado em 09/2016 (Publicada originalmente em Carta na Escola).

A presente análise busca mostrar como o discurso sobre sucesso ou fracasso escolar foi se estabelecendo em torno do Pisa, que se tornou o marco referencial de qualidade no âmbito educacional mundo afora. Dessa forma, é fundamental compreender como surgiu a OCDE (Organização para a Cooperação e Desenvolvimento Econômico), não no sentido de “contextualizar" o Pisa, mas de mostrar como práticas institucionais (e também discursivas) se estabeleceram no correr dos anos.

Nesse sentido, é importante perceber que, no que refere ao Pisa, o discurso gira em torno da filiação discursiva dos sentidos mobilizados pelo que se diz sobre a OCDE, organizadora do exame, como se vê no parágrafo 2, cujo ponto central trata da aparente falta de compatibilidade na atuação da OCDE no campo educacional, uma vez que é uma instituição essencialmente voltada para questões econômicas. Este ponto está diretamente ligado ao modo como os sujeitos se inscrevem em determinadas Formações Discursivas. Por isso, o estranhamento no fato de economistas opinarem acerca de fatos educacionais: "No primeiro anúncio, professores e acadêmicos lamentaram que uma instituição formada por 
economistas se pusesse a dizer o que os alunos deveriam saber [...]" (2-1, 2-2). Assim, professores e acadêmicos estão filiados a determinada formação discursiva e economistas, em outra(s). Em outras palavras, significa afirmar que economistas não seriam autorizados a produzir sentidos relacionados ao campo educacional (cf. Foucault, 1999).

Na sequência do parágrafo (2-3 a 2-5), é abordado que o resultado positivo da Finlândia que, segundo o texto, "já mundialmente famosa por seu sistema educacional de alta qualidade" (2-4), seria o fato responsável pela aceitação do Pisa no cenário internacional pois "fazia sentido" $(2-3,2-4)$ ter o país sabidamente com o melhor sistema de ensino na primeira posição do ranking. Assim, o artigo coloca a argumentação numa lógica quase simplista, na medida em que considera que as críticas em relação ao Pisa encontraram suas respostas no fato de que o teste mostrou que, de fato, "estava certo", isto é, apesar de serem economistas e, portanto, distantes do campo educacional, acertaram na realização da prova e, dessa forma, merecem o crédito.

Observa-se, no entanto, que em Educação Internacional e Comparada não trabalhamos com a noção linear de tempo, mas, de forma complexa, adota-se uma perspectiva em que o tempo assume diversas configurações, não somente como fluxo constante, mas como um turbilhão, com movimentos, muitas vezes, contraditórios entre si (cf. Bray, 2015, p. 197). Nesse sentido, considerar que o Pisa passou a ser aceito pela comunidade internacional simplesmente porque os resultados do primeiro teste realizado no ano 2000 foram condizentes com a "verdade" dos fatos é, na verdade, uma simplificação grosseira do que, de fato, foi o processo de constituição do Pisa como o principal exame internacional e, ao logo do tempo, como referência do que é um sistema de ensino de qualidade.

Como contraponto, é preciso considerar que o processo de construção de sentidos não é uma via de mão única em linha reta, mas um constante movimento de idas e vindas, em que o tempo discursivo nem sempre (ou quase nunca) coincide com o tempo cronológico (cf. Orlandi, 1990, p. 14). Daí decorre que discursos podem assumir "novas roupagens" com os mesmos sentidos ou, ao contrário, o mesmo discurso significando de formas totalmente inesperadas. Assim sendo, não se pode falar em discurso fundador, o que se diz sobre o Pisa 2012. Na mesma direção, nem mesmo o discurso sobre o Pisa 2000 - o primeiro exame realizado - não pode ser considerado fundador, pois já havia discursos sobre a OCDE circulando em determinadas regiões discursivas, sobretudo nas formações discursivas ligadas ao discurso econômico. 
Nesse sentido, o discurso que gira em torno da OCDE gravita em torno de inúmeras outras regiões discursivas, tais como o imperialismo estadunidense, as relações estabelecidas pelo capitalismo a partir da II Guerra Mundial. Assim, a OCDE nasce diretamente da necessidade de sustentação dos mercados consumidores, materializada na reconstrução da Europa, a partir dos interesses dos Estados Unidos que viam nesse processo uma grande oportunidade de fazer dinheiro ao ofertar ajuda financeira a uma Europa devastada pela guerra e, portanto, sem outra saída em vista. Junte-se a isso, o início da Guerra Fria e, novamente, o capitalismo como mola propulsora das ações, uma vez que havia, também o receio de que a União Soviética se impusesse como força motriz da reconstrução europeia. Assim, a Organização para a Cooperação e desenvolvimento Econômico se estabelece como um dos principais organismos internacionais de fomento de políticas voltadas para o campo econômico a fim de promover ascensão dos países membros nesse campo.

Ora, é impossível que os subprodutos derivados dessa ação principal não tenham também elementos desse espírito da economia, do capitalismo e da competição. Dessa maneira, o Pisa surge como uma forma de levantar informações dos países membros a fim de fomentar políticas no campo educacional, mas com vistas (direta ou indiretamente) à inserção dos indivíduos no mercado consumidor, isto é, no mundo capitalista.

Nesse sentido, o presidente do INEP em 2013, Luiz Cláudio Costa, afirma, no texto de apresentação dos resultados brasileiros no Pisa 2012, que:

Apesar dos avanços citados, reconhecidos internacionalmente, a educação no Brasil ainda está em um patamar muito distante daquele ambicionado pela sociedade, que destaca a educação como o alicerce mais estável da competitividade econômica e da superação das desigualdades sociais e regionais. (OECD, 2013)

Pode-se destacar neste trecho que a educação, segundo a visão da OCDE e, consequentemente, dos países participantes do Pisa, é de que é preciso construir um sistema educacional sólido para ser o "alicerce mais estável da competitividade econômica". É interessante que, embora o texto cite a "superação das desigualdades sociais e regionais", o primeiro tópico citado está ligado aos impactos que a educação teria na economia de um país. Assim, é preciso ser competitivo no campo educacional e o meio para atingir tal finalidade é a educação que, gradativamente, a partir desse discurso capitalista, coloca-se apenas como ponte para criar indivíduos mais competitivos. 
Obviamente, não se pode afirmar categoricamente que os discursos sobre o Pisa e também sobre a OCDE estão ligados a determinadas formações discursiva somente porque a origem desse organismo está intimamente relacionada à visão capitalista de mundo, isto é, a ideia de que a educação é somente base para uma economia competitiva. Ao mesmo tempo, não se pode negar a influência que tal forma de ver o mundo exerce nesses discursos. Desse modo, constrói-se historicamente uma maneira particular de falar sobre o Pisa e, de forma mais complexa, modos próprios de falar em nome do Pisa, que, quase necessariamente, passa pela visão de que a educação está subordinada ou, também, pode ser vista como trampolim para uma economia forte. As questões ligadas à formação do indivíduo numa perspectiva mais ampla ficam em segundo plano, conforme se pode ver no parágrafo 3 a matéria. As "habilidades contabilizadas numericamente" (3-2, 3-3) são colocadas no centro do campo semântico ligado à qualidade ou ao fracasso no ensino.

Dessa forma, o ranqueamento se configura como peça central, na medida em que passa a ser uma marca visível dessa "qualidade contabilizada numericamente". Nesse processo, o jogo de construção de sentidos gira em torno das relações de poder estabelecidas entre os participantes do Pisa, tendo o ranking dos resultados como elemento primordial da circulação do discurso da qualidade associada ao bom desempenho na prova, como o artigo afirma no início do parágrafo 3: "A cada edição há mais participantes e os resultados tornaram-se aguardados por imprensa e governos" (3-1, 3-2). Assim, estabelece-se um circuito para o discurso da qualidade associada às primeiras posições nos rankings divulgados pela OCDE na medida em que "imprensa os governos" farão interpretações desses resultados a partir de outras formações discursivas, produzindo e colocando em circulação, consequentemente, outros sentidos.

Nessa cadeia de sentidos, observa-se que ranquear é, também, silenciar, pois, de um lado, a imprensa fará os recortes que lhes são convenientes, destacando determinados pontos em detrimento de outros e, por outro, os governos poderão adotar determinadas políticas e não outras. É o que, em Análise de Discurso, chama-se de política do silêncio (cf. ORLANDI, 1990, p. 49). A partir desse cenário, vê-se que alguns países têm mais voz, outros menos, outros, ainda, nenhuma possibilidade de ser ouvido. Assim, o ranking se dá não só pela via do resultado no Pisa, mas, também, pela importância de cada país no cenário políticoeconômico internacional. 
Em relação à matéria analisada, é possível perceber essa política do silêncio de forma mais explícita no parágrafo 22: "Os países participantes do Pisa têm direito a sugerir questões que são analisadas por especialistas e depois colocadas aos demais. Nenhuma pergunta brasileira fez parte do exame até hoje" (22-1, 22-2). Nota-se que todos "têm direito", entretanto, nem todos fazem parte efetiva da construção do teste propriamente dita. Não é preciso ir muito além para perceber que o silenciamento de alguns países da montagem do teste já mostra o funcionamento ideológico na raiz do Pisa, isto é, no alicerce fundamental: as questões que compõem o teste.

Se, novamente, voltarmos os olhos para o processo de criação da OCDE, é possível perceber, atualmente, semelhante movimento, pois a voz é dada àqueles que interessam aos agentes que detém o poder (político e econômico). Do mesmo modo que a ajuda estadunidense à Europa no pós-guerra não era uma mera ação de caridade, mas tinhas fortes interesses econômicos e políticos embasando tal ação, o modo de operar da OCDE, hoje, segue essa mesma linha. O Brasil participa do Pisa como membro não efetivo da OCDE, entretanto, sofre com essa condição na medida em que não tem voz ativa na construção do exame.

Dessa forma, funciona nesse processo, mais do que uma relação entre dito e nãodito, ocorre, de fato, a efetivação da política do silêncio mencionada anteriormente. Portanto, a questão não é quem disse algo ou o que foi deixado em silêncio, mas como ocorre esse processo de silenciamento (cf. ORLANDI, 1990, p. 51). Neste caso, nega-se a determinados países participantes a possibilidade de se colocar nos testes como participante efetivo. Reforça-se, assim, a condição marginal do Brasil no cenário da internacional da educação. 


\subsection{2 - Análise Discursiva do Texto 8}

A matéria do jornal Folha de S. Paulo comenta os resultados do Brasil no Pisa 2012, divulgados em dezembro de 2013. No texto, são abordados os avanços do país em Matemática, bem como enfatiza a avaliação do então ministro da Educação Aloizio Mercadante referente ao desempenho brasileiro no exame internacional. No centro da análise está o modo como os discursos sobre o Pisa são articulados tanto pelo jornal quanto pelo ministro.

\section{Brasil teve 'grande avanço' no Pisa, afirma Mercadante}

O ministro Aloizio Mercadante (Educação) fez um balanço positivo da evolução do 1 Brasil no Pisa, especialmente na área de matemática. A prova, organizada pela OCDE (Organização para a Cooperação e Desenvolvimento Econômico, que reúne países industrializados) é a principal avaliação internacional da educação básica.

"A nossa fotografia ainda não é boa e não temos que nos acomodar com isso. Porém, o

2 nosso filme é muito bom. Quando olhamos o filme, somos o primeiro da sala", disse Mercadante na manhã desta terça-feira (3), em coletiva de imprensa.

Apesar de avanços na educação, Brasil ocupa baixa posição em ranking

Em matemática, o Brasil registrou uma pontuação de 391 em matemática. Segundo o relatório sobre o desempenho brasileiro no Pisa, o país foi aquele que registrou maior salto, desde 2003, na performance em matemática - a área foi o foco da prova aplicada em 2012. Naquele ano, a pontuação dos estudantes brasileiros foi de 356.

Em matemática, o topo do ranking é ocupado por Xangai, com 613 pontos (119 acima 4 da média dos países analisados).

Para Mercadante, iniciativas como competições escolares estimulam o aumento da

5 performance dos estudantes. "Uma das iniciativas relevantes que ajudam é a olimpíada da matemática. Isso mobiliza muito a rede, os gestores, gera muito autoestima e motivação dos estudantes. Esse é um dos instrumentos que ajudou decisivamente no salto de qualidade na década."

Estudantes de 18 Estados tiveram nota abaixo da média nacional - o pior deles foi 6 Alagoas (342). No extremo oposto, está o Distrito Federal, com 416 pontos. São Paulo teve 404.

O documento ainda aponta fatores positivos nesse período, como o aumento do número

7 de jovens de 15 anos matriculados na educação básica - de $65 \%$ naquele ano para $78 \% \mathrm{em}$ 2012. Segundo Mercadante, esse crescimento representa um aumento de 420 mil estudantes.

No entanto, a OCDE pondera que o Brasil precisa "buscar formas mais eficazes para

8 trabalhar com os alunos de baixo desempenho, a fim de estabelecer expectativas elevadas para todos".

9 Em todas as áreas analisadas - ciência, leitura e matemática - o Brasil ficou abaixo da média dos países analisados.

Em 2012, o Pisa foi realizado por 510 mil estudantes de 65 países. No Brasil, 18.589

10 estudantes fizeram a avaliação - eles estão matriculados em 767 escolas, públicas e privadas. 


\section{INVESTIMENTO}

O ministro ressaltou ainda a diferença de gasto em educação entre os países analisados.

11 Com base em dados de 2010, o Brasil teria investido anualmente US\$2.571,00 por aluno do ensino médio. A média da OCDE é de US\$ 9.014,00

"Estamos comparando com países que investem muito mais em educação do que o

12 Brasil. Acho que foi um grande avanço e merece ser reconhecido e valorizado, apesar de termos muito trabalho pela frente."

\section{CIÊNCIA E LEITURA}

13 O Brasil alcançou 410 pontos em leitura - a média geral é de 496. Já em ciência a pontuação foi de 405 , frente à média de 501 .

De acordo com o relatório da OCDE, $61 \%$ dos alunos brasileiros tem desempenho fraco

14 em ciência, "o que significa que, na melhor das hipóteses, eles podem apresentar explicações científicas óbvias que seguem explicitamente uma evidência dada" na prova.

15 O docume

Texto 8: Brasil teve 'grande avanço' no Pisa, afirma Mercadante. Publicado por Flávia Foreque, em 03/12/2013, na Folha de S. Paulo.

Disponivel em http://www1.folha.uol.com.br/educacao/2013/12/1380024-brasil-teve-grande-avanco-no-pisaafirma-mercadante.shtml, acessado em 17/07/2016.

O primeiro aspecto a ser observado diz respeito ao título, especificamente as aspas assinalando a expressão "Grande avanço": "Brasil teve 'grande avanço' no Pisa, afirma Mercadante". As aspas funcionam no texto como elemento descontinuador da linearidade semântica, uma vez que indica que determinado trecho deve ser lido de uma forma específica, seja por se tratar de uma citação, de um trecho em outro idioma, uma gíria, dentre outras possibilidades (cf. AUTHIER, 1990). Especificamente em relação ao título do artigo da Folha de S. Paulo, observa-se que as aspas produzem um deslocamento semântico, de modo que o trecho sinalizado aponta para outras possibilidades de interpretação, como um dado explícito daquilo que é intrínseco ao funcionamento da linguagem, isto é, não linear e sempre polissêmica. Desse modo, as aspas só deixam à mostra o que a Análise de Discurso entende como base do processo de construção de sentidos, isto é, o fato de que os sentidos sempre podem ser outros, independentemente do modo como uma sentença está construída tanto em termos sintáticos quanto em relação à semântica.

Assim, independente do que se quis dizer com as aspas no texto, o que se pode afirmar, certamente, é que não se trata, de fato, de um grande avanço o resultado brasileiro no 
Pisa. Se analisarmos o trecho em contraste com o restante do texto, pode-se apenas inferir que se trata de ironia, isto é, as aspas querem dizer que, na verdade, não houve qualquer avanço no Pisa. Portanto, o texto, já no título, joga com os sentidos na medida em que apresenta uma fala do ministro e, por meio das aspas, também emite sua opinião, que ficaria "traduzida" da seguinte forma: Mercadante afirma que Brasil teve grande avanço no Pisa, mas, na verdade, não foi isso que ocorreu. Dessa forma, não estamos deduzindo o que se pretendeu com as aspas, mas como funcionam no texto, ou seja, não se trata de um trabalho de adivinhação, mas é a própria materialidade do texto que nos informa a respeito das possibilidades de significação.

Passando ao corpo do texto, percebe-se que há uma constante preocupação a posição do Brasil frente a outros países. Um dos objetivos do Pisa é possibilitar a comparação entre os países, uma vez que

Os procedimentos relativos à aplicação e à amostragem são comuns a todos os países, e são responsáveis por manter padrões de comparabilidade internacional que permitem observar os resultados dos diversos países em uma mesma escala de conhecimento ao longo das diversas edições. (OECD, 2013, p. 01)

É preciso ressaltar, contudo, que comparar não é necessariamente ranquear. Podese, dessa forma, afirmar que está no imaginário de quem fala sobre o Pisa que, por se tratar de um instrumento comparativo, esse tipo de prova serve para distribuir os países em uma tabela e, a partir daí, constatar quem é melhor ou pior.

Um primeiro trecho em que podemos observar a lógica dos rankings no discurso é o parágrafo 2: “A nossa fotografia ainda não é boa e não temos que nos acomodar com isso. Porém, o nosso filme é muito bom. Quando olhamos o filme, somos o primeiro da sala" (2-1, 2-2). Aqui, vemos que o então ministro da Educação entende o processo educativo como uma competição. Em 2-2, ele defende que, ao olhar a história brasileira no Pisa, é preciso considerar que a evolução do Brasil é significativa. Para o ministro, nesse quesito, "somos o primeiro da sala”. Está aí a lógica do ranqueamento como norteador do processo educativo. A sala de aula, por essa fala, é, na visão de Mercadante, uma questão de ranqueamento. Assim, se "somos o primeiro da sala", há, consequentemente, os que são os últimos da sala.

Nessa mesma linha, mais adiante no texto, afirma ainda que "iniciativas como competições escolares estimulam o aumento da performance dos estudantes" (6-1, 6-2). Sem um ambiente competitivo, na ótica de Aloizio Mercadante, o crescimento dos alunos estaria 
estagnado. Corrobora, dessa forma, com a visão de Luiz Cláudio Costa, presidente do INEP durante o período de realização e divulgação dos resultados do Pisa 2012, "que destaca a educação como o alicerce mais estável da competitividade econômica" (OECD, 2013). Portanto, o processo educacional deve estar subordinado à agenda econômica, entendida como o a instância geradora de demanda para o campo educacional que, nessa lógica, é apenas um fornecedor de mão de obra.

Assim sendo, mais do que ser "a principal avaliação internacional da educação básica" (1-4), o Pisa está nos discursos como um modo de conceber a educação nos mais diversos países, imprimindo a lógica da competição e colocando em segundo plano questões de ordem social ou regional. Vê-se, portanto, um processo de homogeneização dos sistemas de ensino mundo afora, de modo que os países almejam um bom resultado no Pisa, que é traduzido por imprensa e governos como exemplo de qualidade.

Lógica semelhante pode ser observada no trecho 3, quando se afirma que "Apesar de avanços na educação, Brasil ocupa baixa posição em ranking". Neste excerto, temos uma locução adverbial (apesar de) que indica concessão, isto é, exprime ideias em contrastantes ou mesmo contraditória na mesma sentença. Aqui, temos os "avanços na educação", de um lado, e a "baixa posição em ranking" do outro. Percebe-se que estar em "baixa posição em ranking" não era a consequência esperada a partir da constatação dos avanços na educação. Novamente, o imaginário em torno do Pisa cria, por meio do trabalho da ideologia, a nítida sensação de que há uma relação natural entre Pisa e qualidade na educação. Portanto, um país que promove melhorias na sua estrutura educacional deve, como consequência, figurar entre os primeiros no ranking do exame organizado pela OCDE. Em outras palavras, a partir do que foi dito no trecho 3, os avanços na educação brasileira foram insuficientes já que o país ocupa uma posição na parte de baixo do ranking.

Há, dessa maneira, um campo discursivo que gravita em torno dos discursos sobre a OCDE e, por consequência, a respeito do Pisa, de modo que se percebe um arranjo discursivo que corrobora com a ideia de que sucesso no Pisa significa educação de qualidade bem como de que ocupar os últimos lugares nos rankings da OCDE é atestado de fracasso no campo educacional. É precisamente neste ponto que a Análise de Discurso pretende atuar, destacando que sempre haverá outras leituras e outros significados. Além disso, a análise discursiva permitirá desnaturalizar esse processo, fazendo com que haja, no mínimo, um 
estranhamento nessa relação aparentemente clara e óbvia estabelecida a partir do que se diz/escreve sobre o Pisa.

\subsection{Comparação dos discursos sobre sucesso/fracasso escolar a partir dos resultados do Pisa}

Nenhuma comparação textual é absoluta, pois depende essencialmente dos gestos de interpretação que, por sua vez, não são plenamente estáveis nem em termos temporais nem tampouco em relação aos sujeitos. Dessa forma, a comparação dos mesmos textos em condições diferentes produz resultados diversos, pois a discursividade não é um dado do texto e não está lá à espera do analista, mas é resultado de um construto teórico.

Nesse sentido, o objetivo da comparação é tentar mapear o comportamento discursivo nos textos analisados de modo a buscar a compreensão do modo como o Pisa se estabeleceu como parâmetro de qualidade absoluto no cenário internacional. Analisando artigos referentes ao Pisa 2000 - primeira edição - e aqueles que tratam do Pisa 2012 (última edição do exame que teve resultados divulgados), buscamos interpretar os discursos em situação comparativa, observando a dinâmica discursiva e também os jogos ideológicos na construção dos sentidos em torno deste tipo de prova.

O trabalho de comparação, neste caso, funciona quase como um processo de reconstrução da discursividade, pois não acessa a verdade sobre o Pisa, mas os discursos sobre o Pisa, isto é, o que fez desse teste internacional referência de qualidade em âmbito mundial não necessariamente tem causa na própria prova, mas no que se fala/escreve sobre ela, movimentando, assim, determinados sentidos. Observa-se, no que se refere a esse processo de construção e circulação de sentidos, que a análise discursiva e a comparação entre os textos permitem perceber como determinados sentidos são cristalizados em detrimento de outros e, dessa forma, pelo trabalho da ideologia, vai-se definindo o que é qualidade e como o Pisa foi se posicionando no cenário internacional e, quando se fala em posição de dominação, a comparação deve passar, obrigatoriamente, pela questão ideológica.

Se compararmos, inicialmente, os textos de 2001, veremos que, embora sejam referentes ao Pisa 2000, primeira edição, percebemos o discurso da qualidade vinculado aos resultados do exame como algo consolidado, isto é, como se já fosse óbvia a relação entre os resultados divulgados e a qualidade ou não do sistema de ensino de um país. Assim, os textos de 2001 apresentam os resultados como se isso fosse um retrato da realidade educacional de 
um país e, no caso específico do Brasil, o baixo rendimento no exame internacional indica, obrigatoriamente, que a educação no país é um fracasso.

Da mesma forma, quando comparamos os textos que tratam do Pisa 2012 (publicados em 2013 e 2014), percebemos a mesma lógica dos textos mais antigos. Isso mostra que o Pisa nasce, embora em meio a críticas, discursivamente bem consolidado, uma vez que, já na primeira edição, os sentidos em torno do exame parecem estar cristalizados, delimitados em determinada região do discurso assim como em relação aos textos mais recentes. Dessa maneira, falar do Pisa em 2001 e em 2016 é, de uma certa forma, transitar na mesma formação discursiva e, consequentemente, mobilizar relativamente os mesmos sentidos.

A constatação de que os textos de 2001 parecem já falar de algo consolidado pode indicar que a formação discursiva em que se situam os discursos sobre o Pisa não tem seu início propriamente na primeira edição da prova. Nesse sentido, destaca-se a importância de uma comparação que não seja estanque em relação ao tempo, de modo que a análise se volte somente para o período de publicação de um texto, no caso da comparação temporal sincrônica, ou para um período específico, no caso de uma comparação temporal diacrônica. O olhar deve estar voltado para uma perspectiva mais ampla que veja, quando se trata de comparação textual, não somente as relações imediatas, mas todo o processo sócio-histórico de construção dos sentidos, o que a Análise de Discurso chama de condições de produção do discurso (cf. ORLANDI, 1999).

Assim, os textos que tratam da edição inaugural do Pisa e, também, da primeira participação do Brasil nesse tipo de teste, não inauguram um discurso sobre o Pisa ou, ainda, não tratam do instrumento avaliativo como algo distante da realidade, mas os textos (especificamente os de 2001) abordam a prova como se as relações de sentido estabelecidas fossem, efetivamente, de conhecimento de todos. Em outras palavras, é como se falar sobre Pisa significasse, de forma óbvia e natural, que sistemas com boas notas no exame são os melhores e, em contrapartida, os que estão na parte de baixo do ranking são países que precisam promover melhorias no campo educacional.

É justamente nesse ponto que a comparação de textos, subsidiada pela análise discursiva, permite compreender como proceder com os gestos de interpretação, pois desnaturaliza as relações, fazendo com que nada pareça óbvio. Assim, a comparação dos quatro textos sobre o Pisa permite-nos propor um outro modo de leitura, destacando que a 
evidência, a transparência dos sentidos, na verdade, são frutos de processos históricos nem sempre lineares e objetivos.

Dessa maneira, quando comparamos os discursos, sobretudo nos textos de 2001, podemos observar que o trabalho ideológico no processo de construção de sentidos relacionados ao Pisa não aponta para um discurso fundador, mas para processos históricos que vão constituindo, ao longo do tempo, modos de falar sobre o Pisa, fazendo com que determinadas formas de falar, determinados significados sejam cristalizados e colocados como os únicos possíveis, como, por exemplo, a afirmação de que ir bem no Pisa é sinônimo de educação de qualidade ou inverso, isto é, quando maus resultados no teste internacional indicariam, necessariamente, que se trata de um sistema de ensino fracassado.

Por ter surgido de um organismo cujo foco sempre esteve na economia, um dos pontos centrais em relação ao Pisa é o profundo elo entre educação e competitividade, perceptível, sobretudo, a partir da observação do meio de divulgação escolhido pela OCDE para apresentar os resultados (tabelas em formato de ranking), que não está alheio aos sentidos que circulam a respeito do teste. Dessa forma, ranquear a educação dos países a partir dos resultados de um teste, conscientemente ou não, é uma forma de sinalizar, de fato, quem são os países que figuram nos quadros de poder do mundo atual não somente no âmbito educacional, mas, sobretudo, no que se refere ao poderio econômico e político. Assim, o discurso do sucesso e do fracasso relacionado à posição no ranking, embora a OCDE classifique o Pisa como um estudo comparado, isto é, apenas uma forma de situar um país em relação ao outro sem, com isso, emitir qualquer juízo de valor, o discurso, por exemplo, da imprensa e dos governos são construídos em torno da ideia fragmentada de que os resultados do teste se limitam às posições de um ranking.

Nesse sentido, não nos cabe julgar se tal ação é ou não intencional, pois o que importa aqui são os efeitos que tal modo de organizar os resultados produzem nos discursos. O principal impacto dessa forma de configuração discursiva é o espírito de competição que se instaura nos países e, no caso do Brasil, as reportagens analisadas trazem essa característica de forma bem marcada. No caso do texto de 2001 que faz um paralelo entre futebol e o Pisa, isso fica ainda mais evidente. Entretanto, nos outros textos, de alguma forma, esse foco na competição também se faz presente, como no texto de 2013, que menciona a fala do ministro da Educação abordando a importância das Olimpíadas de Matemática como elemento 
fomentador da competição no ambiente escolar que, segundo ele, é fundamental para o desenvolvimento dos estudantes.

Esses dois exemplos mostram que o discurso da imprensa sobre o Pisa, embora fragmentado por não discutir o relatório divulgado pela OCDE em sua completude, produz o efeito de verdade a repeito do ranking, gerando a ilusão de que representa, de algum modo, a verdade a respeito dos sistemas de ensino. De uma certa forma, é a mesmas características presente no próprio discurso da imprensa como um todo que é extremamente fragmentado sobretudo em função da velocidade com que as notícias são veiculadas, principalmente na internet, como é o caso dos textos analisados.

É importante destacar, contudo, que não se tratam de inverdades as abordagens da imprensa, mas se tratam de textos que levam a discursos que funcionam no campo discursivo do jornalismo. Assim, a fragmentação nos discursos é parte do processo de construção de sentidos e de uma discursividade que envolve a competição, o ranqueamento dos países somente a partir das tabelas divulgadas pela OCDE. O que preocupa, neste caso, é governos e especialistas em educação levarem em conta somente o discurso da imprensa como referência a respeito do que seja uma educação de qualidade. É preciso, dessa maneira, levar em consideração o conjunto das informações fornecidas pela OCDE e, mesmo assim, ponderar acerca do alcance desse tipo de relatório no que se refere a representar ou não uma avaliação completa e precisa de um sistema educacional.

Desmontar um discurso fragmento implica, necessariamente, a oposição de um outro discurso, isto é, um discurso não fragmentado. Entretanto, em Análise de Discurso (cf. PÊCHEUX 1995, ORLANDI, 1999), concebe-se que não é possível haver discursos não fragmentados, o que significaria não estar sujeitos ao funcionamento ideológico e ao movimento da história. Dessa forma, embora seja impossível produzir discursos fora de uma Formação Discursiva e, portanto, fora das implicações de seu funcionamento, é possível produzir gestos de interpretação menos ingênuos, cientes de que há um jogo de interesses em manter o Pisa desta ou daquela forma. A análise discursiva e a consequente comparação entre os textos e seus discursos permitem tal movimento que, embora pareça inócuo num primeiro momento, é o passo fundamental para a promoção de mudanças no modo como se produz discursos sobre o Pisa e sobre testes da mesma natureza. 


\section{CONSIDERAÇÕES FINAIS}

Um dos objetivos centrais deste estudo comparado era, a partir da análise discursiva dos textos, propor uma leitura de mundo menos ingênua. Observamos, a partir das análises de cada texto separadamente e, também, levando em conta os resultados das análises comparadas, que o intento foi alcançado pois foi possível perceber que sempre se pode empreender novos gestos de interpretação.

Nesse sentido, destaca-se como principal mote desta pesquisa, um modo diferente de inserção no campo da Educação Internacional e Comparada, na medida em que, usualmente, não se consideravam textos como unidades de comparação. Metodologicamente, há muitos impactos em como a EIC se estrutura, sobretudo se considerarmos que os textos sempre tiveram um papel intermediário nos estudos comparados, isto é, sempre foram apenas forma de acesso aos multiníveis na Educação Internacional e Comparada (cf. BRAY, 2015). $\mathrm{Na}$ perspectiva que aqui propomos, os textos, de uma certa forma, continuam como pontes, mas não para o real propriamente dito, e sim para os discursos sobre determinado aspecto do campo educacional.

Nessa abordagem, não se busca uma verdade absoluta trazida pelos textos, mas a realidade desses textos. Se levarmos em conta o Quadro Referencial para Análises na Educação Internacional e Comparada (cf. BRAY \& THOMAS, 1995), construído em forma de cubo, será possível observar que trata de abordagens que não têm o texto como protagonista da comparação propriamente dita, que se dá entre a combinação das faces do cubo, constituindo, dessa forma, uma comparação multinível. Com a comparação de texto, essa forma de construção dos estudos comparativos ainda se mostra relevante, entretanto, acrescentamos uma camada anterior ao cubo, que é a comparação dos textos por meio da análise dos discursos.

É preciso observar, contudo, que tratar diretamente com os textos traz, como dissemos, implicações metodológicas que não podem ser desconsideradas. A noção de real fica profundamente afetada por esse nível de comparação pois não se pode tratar os discursos nem como verdade nem como retrato de uma realidade. São, na verdade, insights, momentos do continuum da discursividade, isto é, um processo que não tem um começo identificável nem, tampouco, terá um fim, na medida em que o ser humano significa o mundo sempre por intermédio de algum tipo de linguagem. 
Nesse sentido, o grupo de textos analisados neste estudo, compõem um quadro, ainda que limitado, da circulação dos discursos sobre sucesso e fracasso escolar, sob as mais variadas abordagens. Coloca-se, como consequência o discurso como espaço privilegiado para o entendimento sobre o modo como as sociedades se organizam a respeito de determinado tema, aqui, especificamente, questões ligadas à educação.

Consequentemente, deve-se explorar de forma mais contundente a linguagem a partir dos aspectos ligados à discursividade, pois é aí que as tensões ocorrem antes de impactarem a rotina dos sistemas educacionais. Não significa, contudo, que todos(as) os(as) pesquisadores(as) de Educação Internacional e Comparada devam se tornar analistas do discurso, mas, não obstante, não podemos ignorar o protagonismo que tais questões exercem nos debates acerca dos fatos educacionais. Assim, é fundamental considerar que a linguagem, assim considerada, não exerce um papel de transmissora de informações ou de mero instrumento de comunicação, mas, de forma mais profunda, atua na constituição do próprio mundo como o conhecemos e, dessa maneira, a análise discursiva e a posterior comparação entre os discurso permite-nos percebe como se dá o processo de construção dos sentidos, considerando o funcionamento ideológico como base para que o mundo faça sentido (cf. ORLANDI, 1999).

É nesse funcionamento que se insere o discurso da imprensa. Configura-se, dessa forma, como parte direta do processo de circulação dos sentidos. Assim, determinados sentidos sobre reprovação ou sobre o PISA estarão "autorizados" a circular em detrimento de outros. Compreender, portanto, como essa política de privilégios semânticos funciona é papel de uma pesquisa comparativa cuja unidade básica de comparação são os textos e os discursos. Além disso, essa política dos sentidos não é um processo aleatório, mas profundamente afetado pela história e pelo funcionamento da ideologia, de modo que as relações de poder em uma sociedade dada ou, ainda, se pensarmos em termos globais, são um dos elementos chaves nesse processo de produção e circulação de sentidos. A partir das análises feitas, podemos observar que o discurso da mídia sobre questões específicas do campo educacional cria uma espécie de campo gravitacional discursivo, isto é, determinados sentidos são alçados à condição de verdade e de modelo, como no caso dos discursos sobre a reprovação e sobre o PISA.

Assim, quando falamos no capítulo 2 sobre o discurso sobre a reprovação, percebemos que a lógica discursiva é toda construída em torno da ideia de modelos de escola, 
isto é, há determinados tipos de escolas que são melhores do que outras. É interessante que salta aos olhos nesse tipo de análise, a relação de obviedade com que os discursos são construídos, de modo que os textos parecem, de fato, tratar da verdade objetiva a respeito que seja uma escola ideal. A reprovação, nos textos analisados, é construída em torno da premissa que é necessário filtrar do acesso à permanência dos estudantes, sob pena de colocar em risco a qualidade das instituições ou do sistema, no caso do ensino público, ainda que o termo "qualidade" não seja definido com precisão. Entretanto, é justamente o jogo de dizer e não dizer, de definir sem definir que faz esse tipo de discurso funcionar com eficácia.

Do mesmo modo, em relação ao capítulo 3, observou-se que os discursos sobre o PISA são ancorados em formações discursivas que não nasceram junto com o exame internacional, o que pode ser percebido quando analisados os textos referentes à prova de 2001, primeira edição da prova, em que os textos já tratam o PISA como balizador da qualidade dos sistemas de ensino, e, gradativamente, torna-se a referência principal para a construção das políticas educacionais. Isso, de uma certa forma, sinaliza que o acesso "à realidade" não se dá por um via direta, isto é, os sentidos não estão no mundo nem nos sujeitos, mas nas relações estabelecidas num contexto dado. Dessa forma, os sentidos sobre o PISA não estão no teste nem nos sujeitos que atuam na concepção e na circulação dos discursos sobre a prova, mas nas relações estabelecidas nesse processo, não só no presente, mas no decorrer da história, como, neste caso, a OCDE, responsável pela elaboração do exame.

A partir desses argumentos, é preciso destacar que interpretar como o PISA funciona é, na verdade, olhar para o funcionamento discursivo que constrói as percepções que temos desse teste. Embora sejam imagens, possuem eficácia nos discursos, significando de determinadas formas. Daí, que se tem que escolas que reprovam são melhores do que outras, podendo, como apresentado no capítulo 2 , serem até mesmo consideradas como modelos para as demais.

No processo histórico de construção, as imagens, e consequentemente, determinados sentidos, vão sendo "colados" em palavras e expressões específicas, fazendo com que se tornem naturais, explícitas, evidentes, transparentes. Evidencia, dessa forma, o trabalho da ideologia de fazer os sentidos parecerem claros e sem opacidade. É preciso ressaltar que um estudo comparado em educação subsidiado pela Análise de Discurso mostra- 
se fundamental nesse processo de colocar em evidência que os sentidos não são naturais e nem tampouco estão atrelados às palavras ou aos sujeitos e, portanto, não são imutáveis.

Assim, a articulação da Educação Internacional e Comparada com a Análise de Discurso mostrou-se, neste estudo, produtiva, sobretudo por permitir o acesso a novos gestos de interpretação, permitindo, dessa forma, percebermos, a partir do trabalho de comparação, como os discursos se articulam entre si e com o contexto sócio-histórico que o constitui e, ao mesmo tempo, é também constituído pelo mesmo movimento discursivo.

Assim sendo, podemos afirmar que é na esfera discursiva que os embates ocorrem, desde a organização até a circulação dos discursos, como no discurso sobre qualidade do ensino. O foco em um tipo de escola cujo elemento central é a reprovação não surge do nada nem tampouco se estabelece do nada. Há processos históricos e sociais que o sustentam, fazendo com que pareçam imutáveis e naturais. Entretanto, tais processos estão ancorados no discurso, a partir do trabalho da ideologia. 


\section{REFERÊNCIAS}

ALTBACH, Philip G.; KELLY, Gail P. Introduction: perspectives on comparative education. In: ALTBACH, Philip G.; KELLY, Gail P. (Eds.). New Approaches to Comparative Education. Chicago: The University of Chicago Press, 1986. p. 1-10.

ALTHUSSER, Louis. Ideologia e Aparelhos ideológicos de Estado. Lisboa: Presença; São Paulo: Martins Fontes, 1970

AMARAL, Marcelo Parreira do. Tendências, desafios e potenciais da educação internacional e comparada na atualidade. Rev. bras. Estud. pedagog. (on-line), Brasília, v. 96, n. 243, p. 259-281, maio/ago. 2015.

AUTHIER, Jacqueline. Heterogeneidade(s) Enunciativa(s). Cad. Est. Ling., Campinas, (19): 25-42, jul/dez. 1990.

BONAMINO, Alícia; FRANCO, Creso. Avaliação e política educacional: o processo de institucionalização do Saeb. Cadernos de Pesquisa, no 108, 108, novembro/1999 p. 101-132, novembro/1999.

BONITATIBUS, Suely Grant. Educação comparada: conceito, evolução, métodos. São Paulo: EPU, 1989

BRAY, Mark; ADAMSON, Bob; MASON, Mark (Orgs.), et all. - Brasília: Liber Livro, 2015.

BRAY, Mark; THOMAS, R. Murray. Levels of comparison in educational studies: different insights from different literatures and the value of multilevel analyses. Harvard Educational Review, v. 65, n. 3, p. 472-490, 1995.

CARROLL, Lewis. Aventuras de Alice no país das maravilhas \& Através do espelho eu que Alice encontrou por lá. Tradução: Maria Luiza X. de A. Borges. 2010.

COLEMAN, J. S., Campbell, E. Q., Hobson, C. J., McPartland, F., Mood, A. M., Weinfeld, F. D., et al. (1966). Equality of educational opportunity . Washington, DC: U.S. Government Printing Office.

COWEN, Robert. Educação Internacional e Comparada, vol. 1 COWEN, R. Acting comparatively upon the educational world: puzzles and possibilities. Oxford Review of Education, v. 32, n. 5, p. 561-573, 2006.

DAROS Júnior, Armando. A presença da OCDE no Brasil no contexto da avaliação educacional. Jornal de Políticas Educacionais. $N^{\text {o }}$ 13, janeiro-junho de 2013, pp. 13-20.

EICHENGREEN, Barry; Long, J. Bradford De. The Marshall Plan: History's Most SUCCESSFUL Structural Adjustment Program. National Bureau of Economic Research, Cambridge, MA. November 1991.

FAIRCLOUGH, Norman. Discurso e mudança social. Trad. Izabel Magalhães. Brasília: Editora Universidade de Brasília, 2001.

FERREIRA, António Gomes. O sentido da educação comparada: uma compreensão sobre a construção de uma identidade. In. SOUZA, Donaldo Bello de; MARTÍNEZ, Silvia Alicia (orgs.); Ângela Maria Martins... [et al.]. Educação comparada: rotas d'além mar. - São Paulo: Xamã, 2009. 
FOUCAULT, Michel. A arqueologia do saber. Tradução de Luiz Felipe Baeta Neves, -7ed. Rio de Janeiro: Forense Universitária, 2008.

FOUCAULT, Michel. A ordem do discurso. $5^{\text {a }}$ ed. - São Paulo: Edições Loyola, 1999.

FRANCO, Maria Ciavatta. Quando nós somos o outro: Questões teórico-metodológicas sobre os estudos comparados. Educação \& Sociedade, ano XXI, no 72, Agosto/00

FREIRE, Paulo. Política e educação: ensaios. 5. ed. - São Paulo, Cortez, 2001 (Coleção Questões de Nossa Época; v. 23)

GAMORAN, A., \& LONG, D. A. (2006). Equality of Educational Opportunity: A 40-year retrospective (WCER Working Paper No. 2006-9). Madison: University of WisconsinMadison, Wisconsin Center for Education Research. Retrieved [e.g., December 15, 2006,] from http://www.wcer.wisc.edu/publications/workingPapers/papers.php.

GARCÍA, José M. González. Reflexiones sobre «El Pensamiento Conservador» de Karl Mannheim. Revista española de investigaciones sociológicas, n. 62, p. 61-81. 1993.

GATTI, Bernadete A. Avaliação de sistemas educacionais no Brasil. Sísifo. Revista de Ciências da Educação, 2009, pp. 7-18.

GOMES, Candido Alberto. Educação Internacional e Comparada no Brasil: esboço de agenda. Rev. bras. Estud. pedagog. (on-line), Brasília, v. 96, n. 243, p. 243-258, maio/ago. 2015 .

GOVERNO DO DISTRITO FEDERAL. Estratégia de Matrícula 2016. Portaria $\mathrm{n}^{\circ} 210$, de 09 de dezembro de 2015.

HORTA NETO, João Luiz. Avaliação externa de escolas e sistemas: questões presentes no debate sobre o tema. R. bras. Est. pedag., Brasília, v. 91, n. 227, p. 84-104, jan./abr. 2010.

HORTA NETO, João Luiz. Um olhar retrospectivo sobre a avaliação externa no Brasil: das primeiras medições em educação até o Saeb de 2005. Revista Iberoamericana de Educación. No $42 / 5$ - 25 de abril de 2007.

JULLIEN DE PARIS, M.-A. Esquisse d'un ouvrage sur l'éducation comparée et séries de questions sur l'éducation. Genève: Bureau International de l'Education, 1962 (réimpression de l'édition de 1817).

KAZAMIAS, A. Homens esquecidos, temas esquecidos: os temas histórico-filosóficoculturais e liberais humanistas em Educação Internacional e Comparada. In: COWEN, R.; KAZAMIAS, A. (Org.). Educação Internacional e Comparada: panorama internacional e perspectivas. Brasília: UNESCO, 2012. v. 1, p. 55-79.

KAZAMIAS, A. M. Educação Internacional e Comparada: uma reflexão histórica. In: COWEN, R.; KAZAMIAS, A. (Org.). Educação Internacional e Comparada: panorama internacional e perspectivas. Brasília: UNESCO, 2012. v. 1, p. 173-193.

KELLY, G. P., ALTBACH, P. G.; ARNOVE, R. F. Trends in comparative education: a critical analysis. In: ALTBACH, P. G.; ARNOVE, R. F.; KELLY, G.P. (Org.). Comparative education. New York: Macmillan, 1982. p. 505-533.

LOURENÇO FILHO, Manoel Bergström. Educação Comparada. Rui Lourenço Filho, Carlos Monarcha (orgs.) - 3. ed. - Brasília: MEC/Inep, 2004.

MAINGUENEAU, Dominique. Discurso e análise do discurso. Trad. Sírio Possenti. 1. ed. São Paulo: Parábola Editorial, 2015. 
MAINGUENEAU, Dominique. Doze conceitos em análise do discurso. Org. Sírio Possenti.; trad. Adail Sobral... [et al.]. São Paulo: Parábola Editorial, 2010.

MALET, Régis. Do estado-nação ao espaço-mundo: as condições históricas da renovação da educação comparada. Educ. Soc., Campinas, vol. 25, n. 89, p. 1301-1332, Set./Dez. 2004, pp. 1301-1332.

MARCHETTO, Bruno Queiroz. A Crise de Bretton Woods e a Metamorfose do Poder NorteAmericano: o início da transição da ordem internacional do pós-guerra. Dissertação de Mestrado. Campinas, 2013.

MOSÉ, Viviane. Nietzsche e a grande política da linguagem. $3^{\mathrm{a}}$ ed. - Rio de Janeiro: Civilização Brasileira, 2014.

NOAH, H.J.; ECKSTEIN, M. Towards a science of comparative education. New York: McMillan, 1969.

NÓVOA, António; YARIV-MASHAL, Tali. Comparative research in education: a mode of governance or a historical journey?'. Comparative Education, v. 39, n. 4, p. 423-438, 2003.

NÓVOA, António. Modelos de análise em educação comparada: o campo e o mapa. In. SOUZA, Donaldo Bello de; MARTÍNEZ, Silvia Alicia (orgs.); Ângela Maria Martins... [et al.]. Educação comparada: rotas d'além mar. - São Paulo: Xamã, 2009.

OECD (2013). RELATÓRIO NACIONAL PISA 2012: RESULTADOS BRASILEIROS.

OECD. PISA 2012 Results in Focus: What 15-year-olds know and what they can do with what they know. 2014

OECD. PISA 2012 Results in Focus: What 15-year-olds know and what they can do with what they know. 2014.

ORLANDI, Eni P. Análise de discurso: princípios e procedimentos. Campinas, SP: Pontes, 1999.

ORLANDI, Eni P. As formas do silêncio: no movimento dos sentidos. - 5. ed. - Campinas, SP: Editora da Unicamp, 2002.

ORLANDI, Eni P. Discurso e leitura. - 8. ed. - São Paulo: Cortez, 2008.

ORLANDI, Eni Pulcinelli. Terra à vista: discurso do confronto: velho e novo mundo. São Paulo: Cortez; Campinas, SP: Editora da Universidade Estadual de Campinas, 1990. (Biblioteca da educação. Série 5. Estudos de linguagem; v. 5)

Paulston (1993): PAULSTON, R. G. Mapping discourse in comparative education. Compare, [Oxford], v. 23, n. 2, p. 101-114, 1993.

PÊCHEUX, Michel. Semântica e discurso: uma crítica à afirmação do óbvio. Trad. Eni Pulcinelli Orlandi [et al.] - 2a ed. - Campinas: Editora da UNICAMP, 1995.

Ramalho, V.; Resende, V. Análise de Discurso (para a) Crítica: o texto como material de pesquisa. Campinas: Pontes, 2011.

Resende, V. Análise de discurso crítica e realismo crítico. Implicações interdisciplinares. Campinas: Pontes, 2009b.

Resende, V.; Ramalho; V. Análise de discurso crítica. São Paulo: Contexto, 2009a.

RESENDE, Viviane de Melo; RAMALHO, Viviane. Análise de discurso crítica. São Paulo: Contexto, 2006. 
SATO, Eiiti. Conflito e cooperação nas relações internacionais: as organizações internacionais no século XXI. Rev. Bras. Polít. Int. 46 (2): 161-176 [2003]

SAUSSURE, Ferdinand de. Curso de Linguística Geral. BALLY, Charles; SECHEHAYE, Albert (Orgs.). Trad. Antônio Chelini, José Paulo Paes, Izidoro Blickstein - $27^{\mathrm{a}}$ edição, São Paulo: Cultrix, 2006

SAVIANI, Demerval. HISTÓRIA COMPARADA DA EDUCAÇÃO: ALGUMAS APROXIMAÇÕES História da Educação. ASPHE/FaE/UFPel, Pelotas (10) 5 - 16, Out. 01

SCHRIEWER, Jürgen. Aceitando os desafios da complexidade: metodologia de educação comparada em transição. In. SOUZA, Donaldo Bello de; MARTÍNEZ, Silvia Alicia (orgs.); Ângela Maria Martins... [et al.]. Educação comparada: rotas d'além mar. - São Paulo: Xamã, 2009.

SÓFOCLES. Rei Édipo. Trad. J. B. De Mello e Souza. 2005.

VELOSO, Fernando [et al.] orgs. Educação Básica no Brasil: construindo o país do futuro. Rio de Janeiro: Elsevier, 2009.

WELLER, Wivian. A atualidade do conceito de gerações de Karl Mannheim: perspectivas para a análise das relações entre educação e trabalho. XXIX Encontro Anual da ANPOCS, Caxambu, 25 a 29 de outubro de 2005 b.

WELLER, Wivian. A contribuição de Karl Mannheim para a pesquisa qualitativa: aspectos teóricos e metodológicos. Sociologias, Porto Alegre, ano 7, no 13, jan/jun 2005a, p. 260-300.

WELLER, Wivian. Compreendendo a operação denominada comparação. Artigo submetido para avaliação da revista Educação \& Realidade - UFRGS em 31/05/2016.

WELLER, Wivian. Karl Mannheim: um pioneiro da sociologia da juventude. XIII Congresso brasileiro de Sociologia. 29 de maio a 1 de junho de 2007, UFPE, Recife (PE). 


\section{APÊNDICE}

\section{ORGANIZAÇÃO DOS TEXTOS}

Seguem os textos lidos durante o processo de seleção dos textos que seriam analisados na dissertação. A organização foi feita obedecendo à ordem cronológica de publicação.

1) De péssima a medíocre (23/08/2000, Cláudio de Moura Castro, VEJA Educação)

\begin{tabular}{|c|c|c|c|}
\hline$\bullet$ & Gradações na qualidade da educação. & $\begin{array}{l}\cdot \\
\text { óbvio; } \\
\cdot \\
\cdot \\
\cdot\end{array}$ & $\begin{array}{l}\text { Ensino Fundamental: grande funil; } \\
\text { Melhora na infraestrutura focada no } \\
\text { Como lidar com alunos pobres? } \\
\text { Formação de professores; } \\
\text { Modernização econômica e Globalização; } \\
\text { Perfil dos líderes no campo educacional. }\end{array}$ \\
\hline
\end{tabular}

2) Arqueologia da reprovação (06/12/2000, Cláudio de Moura Castro, VEJA Educação)

\begin{tabular}{|c|c|c|}
\hline Reprovação & $\begin{array}{l}\cdot \\
\bullet \\
\bullet \\
\text { nossa; } \\
\bullet \\
\bullet\end{array}$ & $\begin{array}{l}\text { Distorção idade-série; } \\
\text { Avaliação; } \\
\text { Relação entre pobreza e fracasso escolar; } \\
\text { Países avançados: Educação melhor que a } \\
\text { Repetência: marca de país atrasado; } \\
\text { Cultura da repetência; } \\
\text { Mecanismos de prêmios e punições. }\end{array}$ \\
\hline
\end{tabular}

3) As máquinas de ensinar (25/04/2001, Cláudio de Moura Castro, VEJA Educação)

\begin{tabular}{|c|c|c|}
\hline - & Relação entre novas tecnologias e ensino. & $\begin{array}{l}\text { Novos atores no campo da tecnologia } \\
\text { educacional: computador e internet; } \\
\text { Na época a internet era baseada em textos } \\
\text { e, por isso, "perdia" para o apelo visual da TV; } \\
\text { - Comparar o Brasil com outros países, } \\
\text { vendo os casos de sucesso desenvolvidos aqui. }\end{array}$ \\
\hline
\end{tabular}


4) Questão de método (Agosto/2001, ed. 108, Kristhian Kaminski e Patrícia Gil, Revista Educação)

\begin{tabular}{|l|l|l|}
\hline - Construtivismo x Método fônico & $\begin{array}{l}- \text { Construtivismo só funciona com crianças } \\
\text { ricas; }\end{array}$ & Com crianças pobres, só funciona o \\
método fônico; & \\
$-\quad$ Construtivismo pressupõe & bagagem \\
cultural; & Métodos usados nos países da Europa; \\
\hline
\end{tabular}

5) Lei que transformou forma de ensino no País completa 50 anos (20/12/2001, Cartola Agência de Conteúdo - Especial para o Terra)

\begin{tabular}{|l|l|l|}
\hline - Mudanças na LDB & Inclusão; & \\
- & Mudanças na visão do processo de \\
educação com o advento da recuperação e da \\
dependência; \\
$-\quad$ Pobreza como causadora das \\
desigualdades na educação; \\
$-\quad$ Discrepância entre a lei a "vida real". \\
\hline
\end{tabular}

6) Poderia ser pior, Sr. Ministro? (12/12/2001, Gilmar Piolla, Aprendiz/UOL)

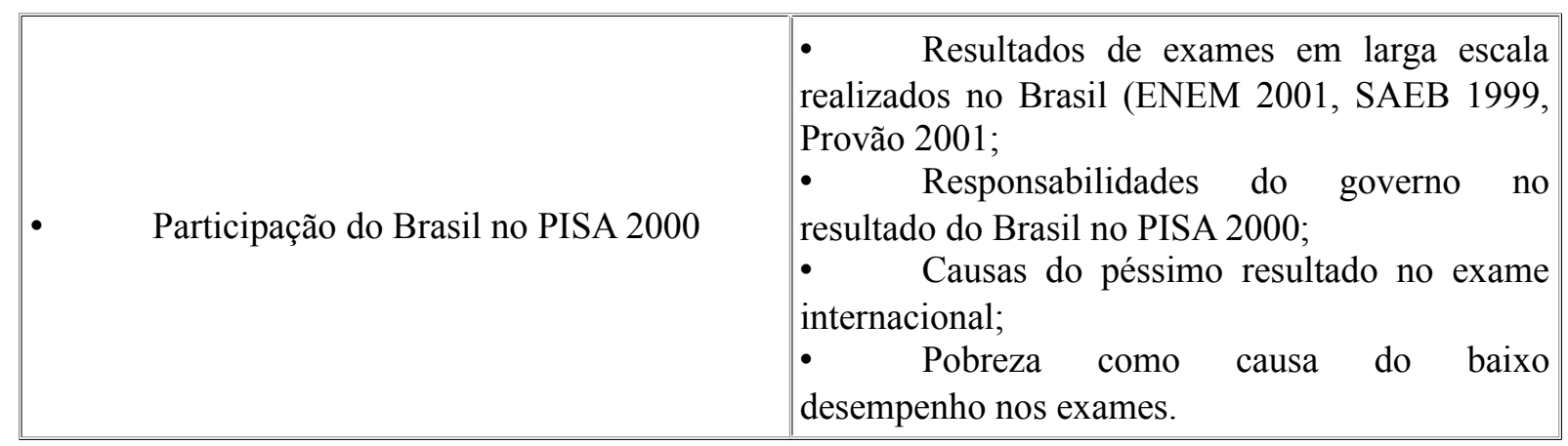

7) A lição de PISA (12/12/2001, Simon Schwartzman, O Globo)

\begin{tabular}{|l||c|}
\hline - Participação do Brasil no PISA 2000 & $\begin{array}{c}\text { Comentários acerca dos resultados do } \\
\text { Brasil no PISA 2000. }\end{array}$ \\
\hline \begin{tabular}{c} 
Análise dos resultados por região. \\
\hline
\end{tabular}
\end{tabular}

8) Ensino Reprovado (2001, Gilberto Nascimento, ISTO É)

\begin{tabular}{|l|ll|}
\hline Reprovação & $\bullet$ & $\begin{array}{l}\text { Papel do docente no ensino } \\
\text { Ciclos }\end{array}$ \\
& $\bullet$ & Progressão continuada \\
\hline
\end{tabular}


9) A hora da sala de aula (08/05/2002, Cláudio de Moura Castro,VEJA Educação)

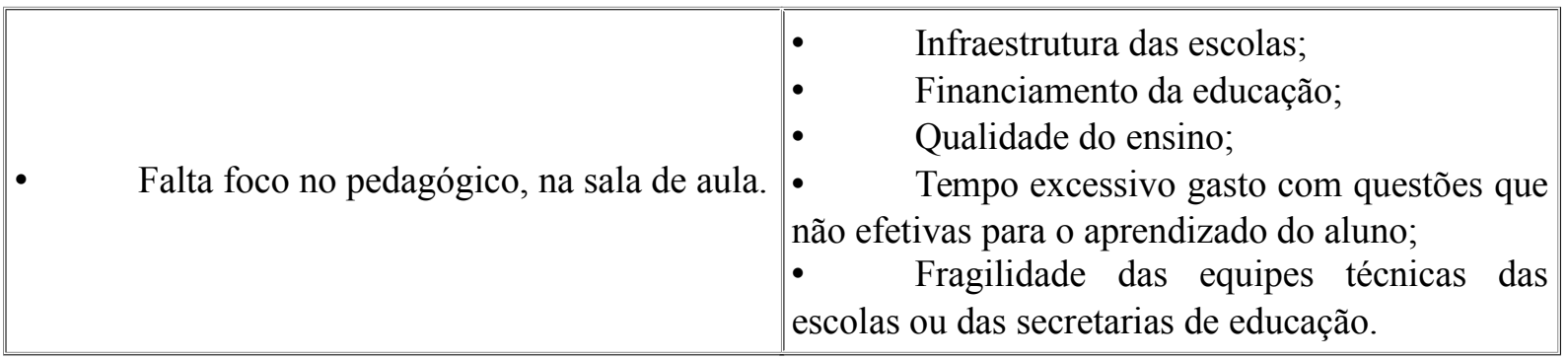

10) Inversão de valores (16/02/2004, João Luís de Almeida Machado, Planneta Educação)

\begin{tabular}{|l|ll|}
\hline - A escola deve preparar "para a vida" ou & $\begin{array}{l}\text { Perfil dos cursinhos preparatórios para o } \\
\text { vestibular; } \\
\text { somente para passar no vestibular? }\end{array}$ & $\begin{array}{l}\text { Escolas de grife; } \\
\text { - }\end{array}$ \\
\hline
\end{tabular}

11) O caminho para a qualidade (Setembro/2008, Rodrigo Ratier, NOVA ESCOLA)

\begin{tabular}{|c|c|}
\hline Qualidade do ensino & $\begin{array}{l}\text { - } \text { Comparação do Brasil com países que } \\
\text { estão no topo dos rankings internacionais de } \\
\text { Educação; } \\
\text { - } \quad \text { Carreira de professor atraente; } \\
\text { - } \quad \text { Formação docente; } \\
\text { - } \quad \text { Cuidar dos altos índices de repetência; } \\
\text { - } \quad \text { Festão bem preparada; } \\
\text { prioridade; o Brasil definir Educação como } \\
\text { - Sistema de avaliação da educação em } \\
\text { todos os níveis. }\end{array}$ \\
\hline
\end{tabular}

12) Formação inicial: a origem do sucesso (e do fracasso) escolar (Outubro/2008, Thais Gurgel NOVAESCOLA)

\begin{tabular}{|c|c|c|}
\hline - & Formação docente & $\begin{array}{ll}\text { - } & \text { Formação inicial; } \\
\text { - } & \text { Formação continuada. }\end{array}$ \\
\hline
\end{tabular}

13) Países com melhores sistemas de ensino podem inspirar soluções (Edição 216, Outubro/2008, Ana Rita Martins/Beatriz Santomauro e Rodrigo Ratier, NOVA ESCOLA)

\begin{tabular}{|l|ll|}
\hline Análise da "fórmula do sucesso" de de & - & Qualidade do professor; \\
países com os melhores sistemas educacionais & $-\quad \begin{array}{l}- \\
\text { Formação docente inicial; }\end{array}$ \\
& $\begin{array}{l}\text { Foco nos alunos com dificuldades; } \\
\text { Currículo e carga horária dos cursos de } \\
\text { pedagogia no Brasil e na Finlândia. }\end{array}$ \\
\hline
\end{tabular}


14) Na formação continuada não basta (só) tapar os buracos (Edição 216, Outubro/2008, Ana Rita Martins/Colaboraram Arthur Guimarães, Beatriz Levischi, Denise Pellegrini, Gustavo Oliveira, Júlia Browne e Maria Slemenson, GESTÃO ESCOLAR).

\begin{tabular}{|l|l|}
\hline Formação Continuada & Cursos teóricos tem ligação com a \\
& $\begin{array}{l}- \\
\text { realidade; }\end{array}$ \\
& Programa dos cursos de formação; \\
- & O papel do coordenador pedagógico; \\
- & Estrutura das secretarias de educação; \\
\hline
\end{tabular}

15) O amor constrói. Mas não ensina a tabuada (12/03/2010, Gustavo Ioschpe, VEJA)

\begin{tabular}{|l|l|r|}
\hline - Pedagogia do afeto & $\begin{array}{l}\text { Concepção de ensino baseado nas } \\
\text { relações amorosas em detrimento do } \\
\text { conhecimento acadêmico; } \\
\text { Para o autor, amor e aprendizagem } \\
\text { parecem impossíveis de se relacionarem; }\end{array}$ \\
\hline
\end{tabular}

16) Repetência: um erro que se repete a cada ano (Junho/Julho 2010, Ronaldo Nunes, NOVAESCOLA)

\begin{tabular}{|l|l|l|}
\hline Repetência & $\begin{array}{l}\text { Comparação do tema principal entre o } \\
\text { Brasil e outros países; } \\
-\quad \text { Associação entre não reprovar com } \\
\text { sucesso em exames internacionais; }\end{array}$ \\
\hline
\end{tabular}

17) Brasil tem maior taxa de abandono escolar do Mercosul (17/09/2010, Ana Okada, Educação UOL)

\begin{tabular}{|l|l|}
\hline - Abandono escolar & $\begin{array}{l}\text { Abandono escolar entre os países do } \\
\text { Mercosul; } \\
-\quad \text { Aprovação e reprovação entre os países } \\
\text { do Mercosul. }\end{array}$ \\
\hline
\end{tabular}

18) "Fracasso escolar é o fracasso do sistema educacional”, diz especialista (20/05/2011 Atualizado em 23/05/2011 -, Paulo Guilherme, G1)

\begin{tabular}{|c|c|}
\hline Fracasso escolar & $\begin{array}{l}\text { - A visão da neurociência sobre o } \\
\text { aprendizado; } \\
\text { Reprovação; } \\
\text { Causas do fracasso escolar; } \\
\text { - } \quad \text { Papel da academia nas decisões na } \\
\text { Educação. }\end{array}$ \\
\hline
\end{tabular}


19) Os segredos da Finlândia (Agosto/2011, Beatriz Rey, Revista Educação)

\begin{tabular}{|l|ll|}
\hline \multirow{2}{*}{ Funcionamento do sistema educacional } & $\begin{array}{l}\text { Características dos alunos; } \\
\text { finlandês }\end{array}$ & $\begin{array}{l}\text { Posição da Finlândia no PISA; } \\
\text { Carreira docente; }\end{array}$ \\
& $\begin{array}{l}\text { Formação docente; } \\
-\end{array}$ \\
\hline
\end{tabular}

20) Por que 34,5\% dos alunos do Ensino Médio não estão na série correspondente à sua idade? (15/09/2012, Marcelo Gonzatto, ClickRBS/Zero Hora)

\begin{tabular}{|l|ll|}
\hline & - & Reprovação; \\
& Distorção idade-série & Evasão; \\
& - & Currículo/excesso de matérias; \\
& Formação docente precária; \\
& Transição Anos iniciais para Anos Finais; \\
& Falta de planejamento governamental. \\
\hline
\end{tabular}

21) 10 lições da Finlândia para a educação brasileira (23/05/2013, EXAME.com)

\begin{tabular}{|l|l|}
\hline Sistema de Ensino da Finlândia. & $\begin{array}{l}\text { O sistema é de qualidade porque tem } \\
\text { bons resultados no PISA; } \\
\text { A qualidade é atestada por agências } \\
\text { internacionais: ONU e OCDE; } \\
\text { Conteúdo ministrado e o papel do } \\
\text { professor. }\end{array}$ \\
\hline
\end{tabular}

22) Brasil teve 'grande avanço' no Pisa, afirma Mercadante (03/12/2013, Flávia Foreque, Estadão)

\begin{tabular}{|l|l|l|}
\hline - Matéria sobre declaração do ministro da & $\begin{array}{l}\text { Confronto das opiniões do ministro da } \\
\text { Educação sobre os resultados no Pisa 2012. }\end{array}$ & $\begin{array}{l}\text { Educação Aloizio Mercadante com dados e } \\
\text { gráficos a respeito do Pisa 2012 para mostrar que } \\
\text { o ministro supervalorizou o desempenho do } \\
\text { Brasil. }\end{array}$ \\
\hline
\end{tabular}

23) Por que reprovar não funciona? (12/11/2013 - Atualizado em 13/11/2013 - Daniel Cara, UOL Educação)

\begin{tabular}{|l|l|}
\hline Reprovação & $\begin{array}{l}\text { "Reprovação não é benéfica ao aluno"; } \\
\text { Reprovação como medida pedagógica; }\end{array}$ \\
$\begin{array}{l}\text { Ciclos x Seriação } \\
\text { Progressão continuada x Promoção }\end{array}$ \\
\hline
\end{tabular}


24) Pisa em seu devido lugar (05/08/2014, Cinthia Rodrigues, Carta Educação/Carta Capital)

\begin{tabular}{|lll|l|l|}
\hline Pisa como referência para políticas & $\begin{array}{l}\text { Análise do Pisa como fomentador de } \\
\text { políticas públicas. } \\
\text { públicas. }\end{array}$ & $\begin{array}{l}\text { Influência dos resultados do Pisa em } \\
\text { outros países. } \\
\text { Como outros países lidam com testes em } \\
\text { larga escala. }\end{array}$ \\
\hline
\end{tabular}

25) Reprovar não é solução, mas aprovar quem não aprendeu é pior (09/12/2014, Andrea Ramalz, G1)

\begin{tabular}{|c|c|c|}
\hline • & Aprovação/Reprovação & $\begin{array}{l}\text { - Escola boa não reprova; } \\
\text { - Países desenvolvidos já encontraram } \\
\text { soluções melhores que a brasileira para a questão } \\
\text { da repetência; } \\
\text { - } \quad \text { Reprovar não é solução para os } \\
\text { problemas da educação brasileira; } \\
\text { - Progressão continuada; }\end{array}$ \\
\hline
\end{tabular}

26) Sem mudanças, abolir reprovação de alunos é desastroso, diz educadora (18/12/2014, Daniela Mercier, Folha de S. Paulo)

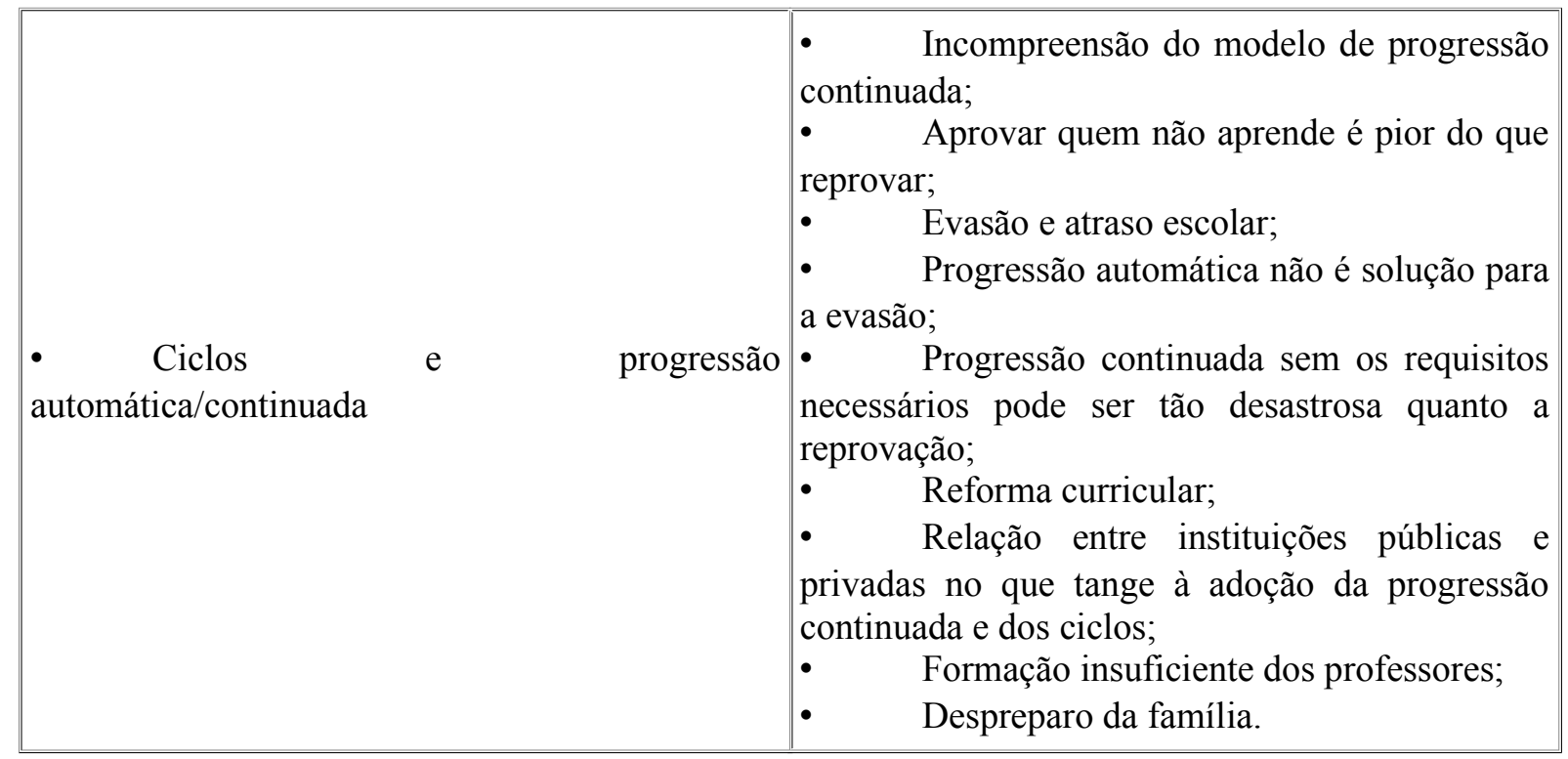

27) Um panorama da educação na América do Sul (acessado em 01/02/2015, Otaviano Helene, Le Monde Diplomatique Brasil)

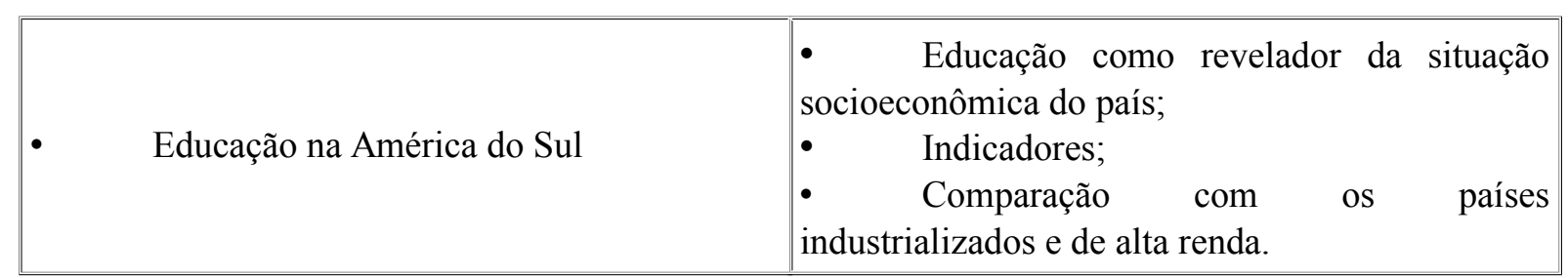


28) Progressão continuada é frequente entre países que se destacam no cenário educacional (27/03/2015, Letícia Larieira, Todos pela Educação)

\begin{tabular}{|l|ll|}
\hline - Progressão continuada & $\begin{array}{l}- \\
\text { - Países desenvolvidos adotam progressão } \\
\text { continuada; } \\
-\end{array}$ & Cultura da repetência; \\
- & Progressão continuada x Reprovação \\
\hline
\end{tabular}

29) O dilema da progressão continuada (31/03/2015, Todos pela Educação)

\begin{tabular}{|c|c|}
\hline Progressão Continuada/Reprovação & 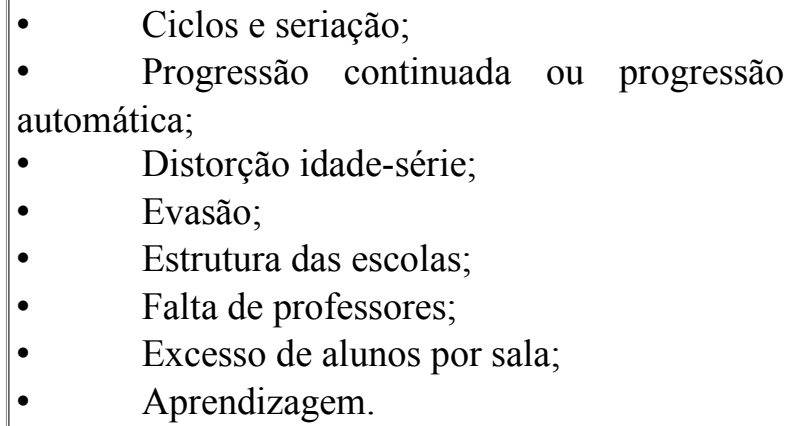 \\
\hline
\end{tabular}

30) “É cuspe e giz" (27/04/2015, Antônio Gois, O Globo)

\begin{tabular}{|l|l|l|}
\hline \multirow{2}{*}{ alunos } & Papel do professor e comportamento dos & $\begin{array}{l}- \\
\text { Relato de professor que volta à sala de } \\
\text { aula } 20 \text { anos depois; } \\
-\quad \text { Professores antigos da escola não } \\
\text { acreditam mais nos alunos; } \\
-\quad \text { Professor novo deslocado da "realidade". }\end{array}$ \\
\hline
\end{tabular}

31) “O fim do jubilamento" (04/05/2015, Antônio Gois, O Globo)

\begin{tabular}{|l|l|}
\hline - Jubilamento/Reprovação & $\begin{array}{l}\text { Exclusão; } \\
-\end{array} \begin{array}{ll}\text { Fim do jubilamento significa queda da } \\
\text { qualidade; }\end{array}$ \\
$-\quad \begin{array}{l}\text { Pobreza e baixo rendimento; } \\
\text { Condições para que todos tenham direito } \\
\text { a aprender. }\end{array}$ \\
\hline
\end{tabular}

32) Colégio Pedro II, no Rio, decide manter alunos repetentes (06/05/2015, Clarissa Thomé, ESTADÃO)

\begin{tabular}{|l|l|}
\hline - Reprovação/Qualidade do ensino & $\begin{array}{l}\text { Reação de pais e de profissionais da } \\
\text { educação; } \\
-\quad \text { Aprendizado; }\end{array}$ \\
\hline
\end{tabular}

33) Sucesso relativo (10/05/2015, Antônio Gois, O Globo)

\begin{tabular}{|l|l|}
\hline - Taxas de reprovação & $\begin{array}{l}\text { Sucesso e fracasso escolar associados à } \\
\text { condição socioeconômica do aluno; } \\
-\quad \text { Interpretação de dados; }\end{array}$ \\
\hline
\end{tabular}


34) Atrasos em série (13/07/2015, Antônio Gois, O Globo)

\begin{tabular}{|c|c|}
\hline Atraso escolar & 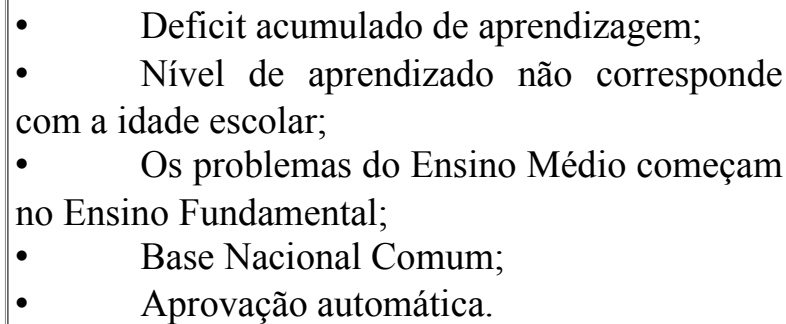 \\
\hline
\end{tabular}

35) Uma escola para se inspirar (20/05/2016, Thais Paiva, Carta Educação/Carta Capital)

\begin{tabular}{|lll|ll|}
\hline $\begin{array}{l}\text { Centro } \\
\text { Salvador Arena. }\end{array}$ & Educacional da & Fundação & $\begin{array}{l}\text { Volume de investimento. } \\
\text { Qualidade no ensino. }\end{array}$ \\
& & & $\begin{array}{l}\text { Restrições à matrícula } \\
\text { Escola modelo. }\end{array}$ \\
\hline
\end{tabular}

